\title{
Lithofacies and Sequence Stratigraphy of the Middle Devonian Marcellus Formation for a Cored Well in Clearfield County, Pennsylvania Using Core Analysis Methods
}

Chloe S. Wonnell

Follow this and additional works at: https://researchrepository.wvu.edu/etd

\section{Recommended Citation}

Wonnell, Chloe S., "Lithofacies and Sequence Stratigraphy of the Middle Devonian Marcellus Formation for a Cored Well in Clearfield County, Pennsylvania Using Core Analysis Methods" (2015). Graduate Theses, Dissertations, and Problem Reports. 6972.

https://researchrepository.wvu.edu/etd/6972

This Thesis is protected by copyright and/or related rights. It has been brought to you by the The Research Repository @ WVU with permission from the rights-holder(s). You are free to use this Thesis in any way that is permitted by the copyright and related rights legislation that applies to your use. For other uses you must obtain permission from the rights-holder(s) directly, unless additional rights are indicated by a Creative Commons license in the record and/ or on the work itself. This Thesis has been accepted for inclusion in WVU Graduate Theses, Dissertations, and Problem Reports collection by an authorized administrator of The Research Repository @ WVU. For more information, please contact researchrepository@mail.wvu.edu. 


\title{
Lithofacies and Sequence Stratigraphy of the Middle Devonian Marcellus Formation for a Cored Well in Clearfield County, Pennsylvania Using Core Analysis Me thods
}

\author{
Chloe S. Wonnell \\ Thesis submitted to the \\ Eberly College of Arts and Sciences \\ at West Virginia University \\ in partial fulfillment of the requirements for the degree of \\ Master of Science in \\ Geology
}

Timothy Carr, Ph.D., Chair

Shikha Sharma, Ph.D.

Peter Sullivan, M.S.

Department of Geology and Geography

Morgantown, West Virginia

2015

Keywords: Marcellus Formation, Core Analysis, Lithofacies, Sequence Stratigraphy Copyright 2015 Chloe Wonnell 


\begin{abstract}
Lithofacies and Sequence Stratigraphy of the Middle Devonian Marcellus Formation for a Cored Well in Clearfield County, Pennsylvania Using Core Analysis Methods
\end{abstract}

Chloe S. Wonnell

In the central Appalachian basin of northeastern United States, the Middle Devonian Marcellus Formation is a very important source rock and hydrocarbon reservoir. Pennsylvania is the center for unconventional Marcellus Formation shale-gas exploration, with the highest production rates being established in the northeastern and southwestern areas of the state. In comparison, Clearfield County, in central Pennsylvania, has relatively lower production rates. Previous research suggested structural complexity in this area. This research provides an analysis of a $173.65 \mathrm{ft}$. $(59.93 \mathrm{~m})$ long core from the Marcellus Formation, which has been interpreted for lithofacies and sequence stratigraphy using core analysis methods.

Seven lithofacies were identified from visual descriptions and quantitative interpretations using traditional core analysis methods, such as core and thin-section description, x-ray diffraction (XRD), total organic carbon (TOC), and spectral core gamma-ray (GR). Ingrain's digital rock physics (DRP) color-coded CoreHD ${ }^{\circledR}$ lithofacies classification was successful at illustrating small-scale variations in the core based off high resolution bulk density (RHOB) and photoelectric factor (PEF) logs. A core-scale lithofacies log and spectral core GR aids in recognizing condensed sections and stacking patterns, which helps establish a sequence stratigraphic framework for the cored well that consists of six stratigraphic intervals. The sequence stratigraphic framework reveals that the Marcellus Formation in the area was deposited during a relatively low energy, shallow sea environment, where degree of anoxia was neither persistent nor widespread like previously thought. Rapid fluctuations in anoxia are attributed to changes in water chemistry, sediment supply, and primary production associated with close proximity to localized bathymetric low and a nearby sediment source. 


\section{ACKNOWLEDGEMENTS}

I would like to express my appreciation to my advisor, Dr. Timothy Carr for supporting this thesis. Thank you for accepting me as your student, providing financial assistance, and guidance throughout this project. I also would like to thank Dr. Shikha Sharma and Pete Sullivan for being on my committee. I sincerely appreciate the time and insights you have given to my research.

I would like to thank Energy Corporation of America for providing the core and log data used in this study. I would like to express my gratitude to National Energy Technology Laboratories for allowing me to use their Source Rock Analyzer to acquire the pyrolysis data analyzed in this research, and to Dr. Harvey Eastman, who personally helped me with the analysis. I also would like to thank Shuvajit Bhattacharya for his willingness to help me, for generously sharing his skill and knowledge, and for generating a stochastic mineralogical model to supplement my research.

I would also like to express my gratitude to my parents for their continuous support and love throughout my college career. I would have never accomplished this without you. I thank Blake Huber for his support and encouragement throughout this endeavor. I also would like to express my thanks to my undergraduate mentors, Dr. William Niemann and Brian Shaffer, for their educational and professional guidance. 


\section{TABLE OF CONTENTS}

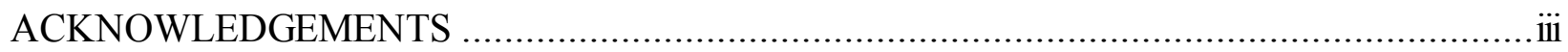

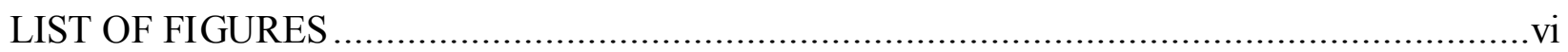

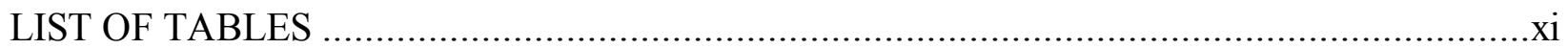

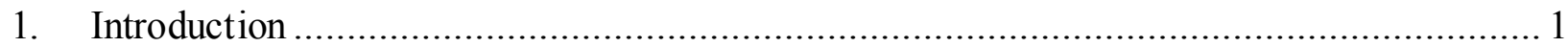

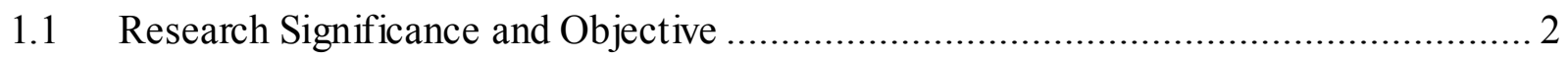

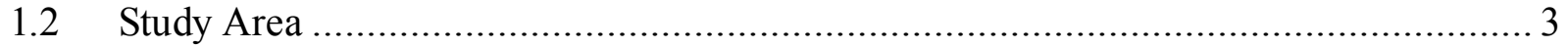

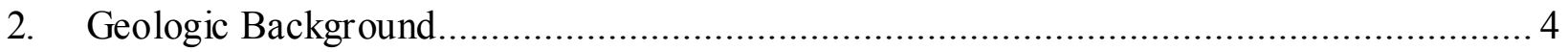

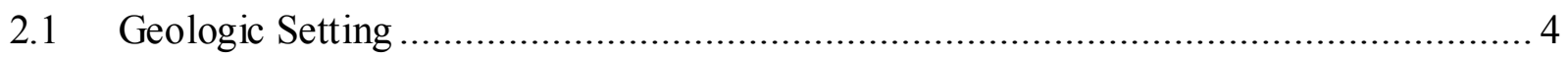

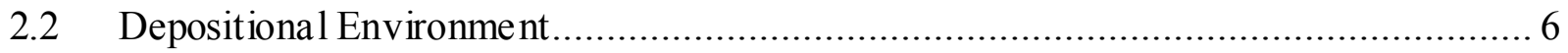

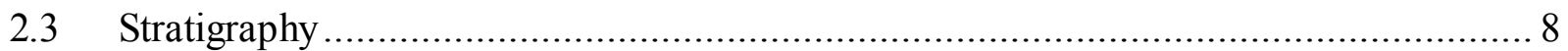

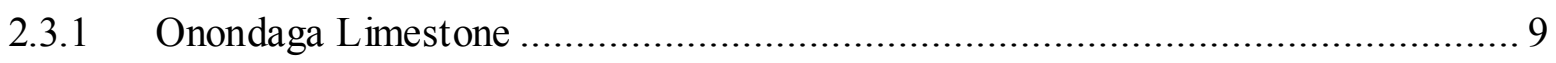

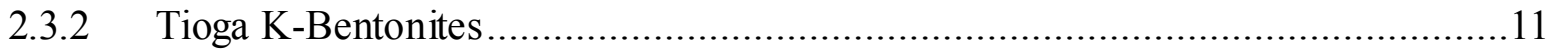

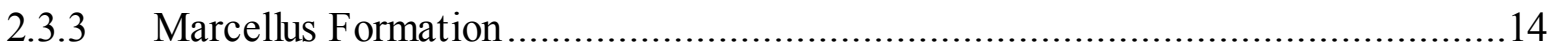

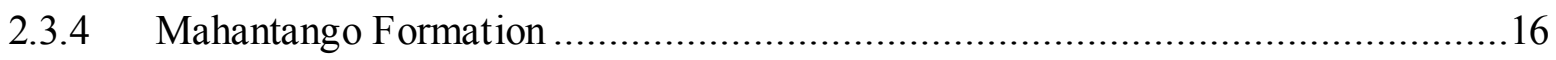

2.4 Sequence Stratigraphy of Study Interval ...............................................................17

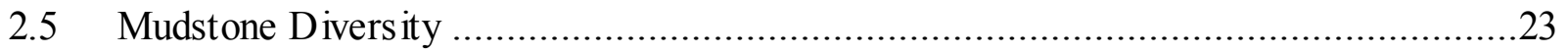

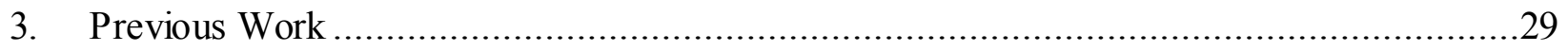

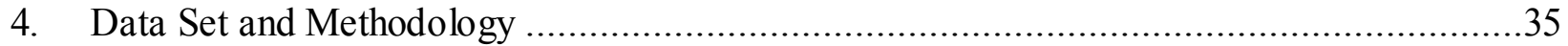

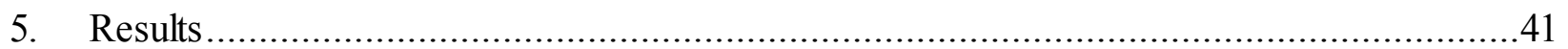

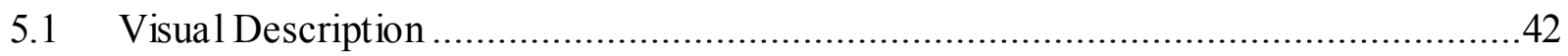

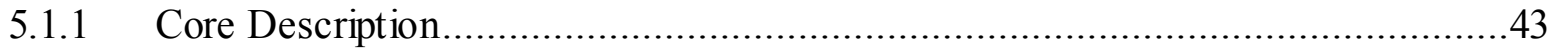

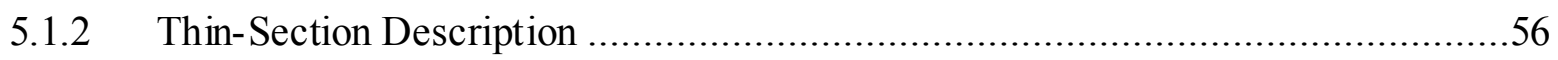

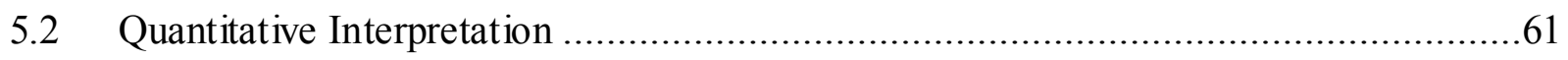

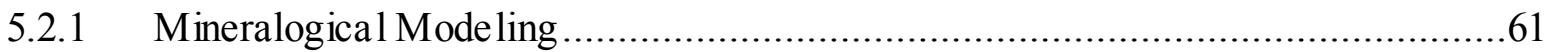

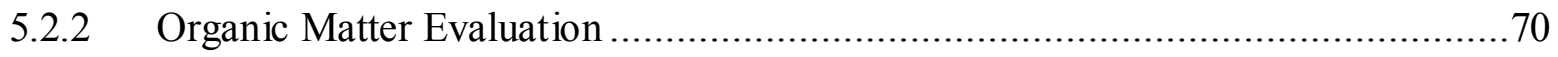

5.2.3 Spectral Core Gamma Ray Log Analys is .......................................................72

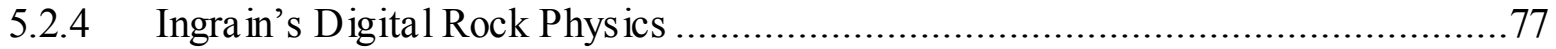

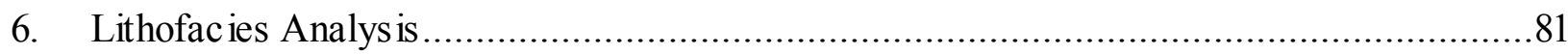

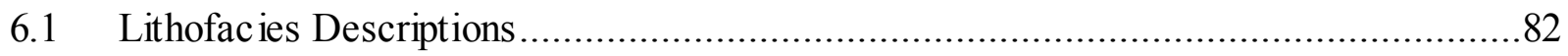




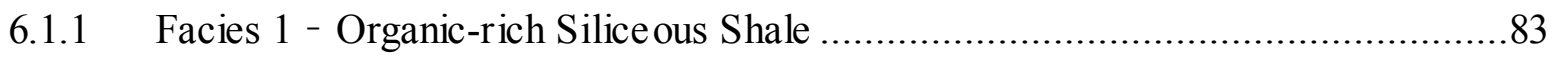

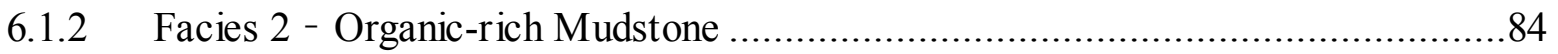

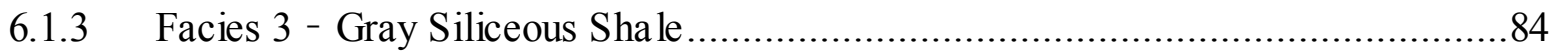

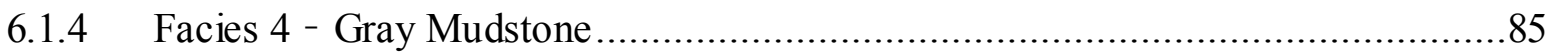

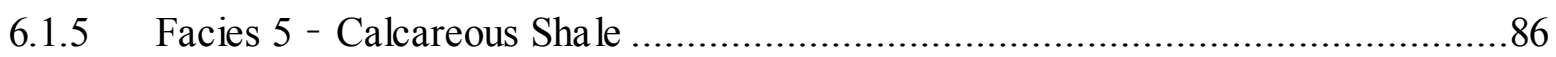

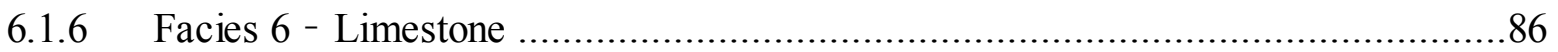

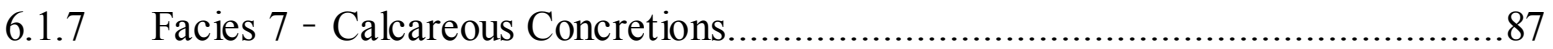

6.2 Depositional Interpretation of Lithofacies .............................................................

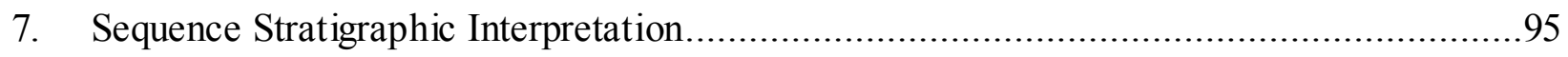

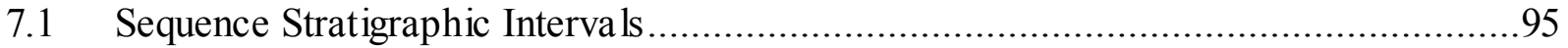

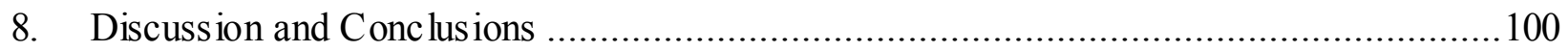

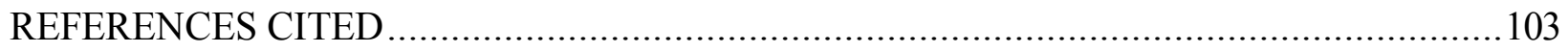

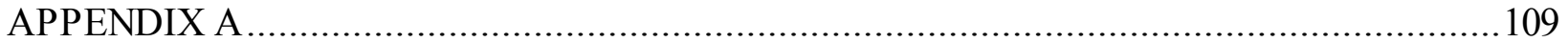

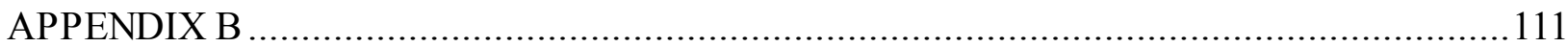

Core Description Key

Core Description 1, Depth: 7126' - 7176'

Core Description 2, Depth: 7076' - 7126'

Core Description 3, Depth: 7002' - 7076' 


\section{LIST OF FIGURES}

Figure 1.1. The Study Area is in Clearfield County, Pennsylvania. It is located in the Appalachian plateau geological provenance in the central Appalachian basin. The Cold Stream Affiliates \#1MH (red well symbol) is the cored well analyzed in this study. Map Modified from Erenpre iss, et al., (2011).

Figure 2.1. Reconstruction of Middle Devonian (385 Ma) paleogeography. Northern Appalachian basin identified (red) with Acadian orogen in the east and the Cincinnati arch to the west (modified from Blakey, 2010). 6

Figure 2.2. Regional facies model of the Acadian Clastic wedge illustrating the five magnafacies of the Appalachian basin. Facies I: dark-gray to black, organic-rich, basinal marine shale. The cross section is from Ohio to central Pennsylvania, with the red star showing the approximate location of Clearfield County, PA, putting the Cold Stream Affiliates \#1MH well in the thicker part of the basin, where sediments appear to be associated with shallower water facies (modified from Harper, 1999). 8

Figure 2.3. This figure illustrates the stratigraphy of the Lower and Middle Devonian in the Appalachian Basin. In this study, the stratigraphic nomenclature used for the Marcellus Formation is highlighted in red (modified from Wrightstone, 2009).

Figure 2.4. Lithologic subdivisions for the Middle Devonian Eifelian to Givetian Strata from ver Straeten (2004 and 2007), Milici and Sweezy (2006), and Kohl et al. (2014). Calibrated time scale derived from Kaufman (2006) and third order depositional sequences from Brett et al. (2011) and ver Straeten (2007). The stratigraphic nomenclature used in this study is on the far right (modified from Kohl, 2014).

Figure 2.5. ECA Coldsteam \#1MH well core photo from Core Labs with five ash beds that Parrish (2013) identified. Radiometric dates are listed in Table 2.1. The ash beds are recognized by their buff color and visible mica flakes (Parrish, 2013). Besides illustrating the ash beds, this core photo shows Onondaga-Lower Marcellus contact. The contact between the OnondagaLower Marcellus is a sharp, low-angle contact, where argillaceous limestone transitions into a calcareous, black shale that is interbedded with limestone.

Figure 2.6. Depositional sequence of a basin margin illustrating different surfaces and systems tracts with parasequence stacking patterns (modified from Bohacs and Schroeder, 2010).

Figure 2.7. Sequence-stratigraphic interpretations from Kohl et al. (2014) for the lower Marcellus Formation. Parasequence sets and systems tracts are identified and abbreviations are defined in the text. Also shown are wireline and graphic logs that guided these interpretations, as well as stratigraphic nomenclature and sequence-stratigraphic interpretations (from Kohl et al, 2014). $\mathrm{GR}=$ gamma ray $\log , \mathrm{RHOB}=$ bulk density $\log , \mathrm{NPHI}=$ neutron porosity $\log , \mathrm{DPOR}=$ density poros ity log, GRES = guard resistivity. 22 Figure 2.8. Sequence stratigraphic type log illustrating the third order depositional systems tracts for the Marcellus Formation from a compilation of wells across the across the basin. The top of 
the Onondaga Formation and bottom of the Mahantango Formation (SKS) are also recognized in this type $\log$ (from Lash and Engelder, 2011).

Figure 2.9. Models of diagenetic zones and products with approximated boundaries that are applicable to relative depth, temperature, and porosity (Tourtelot, 1979).

Figure 2.10. Tertiary diagram of the mineralogical composition of mudrocks and how mechanical and chemical stability relate to pore space. Clay is relatively unstable mechanically and chemically making clay minerals more susceptible to deformation from compaction. Carbonate, phosphate and feldspar minerals are mechanically stable but chemically susceptible to dissolution, while quartz and pyrite are the most stable and less likely to sustain major pore loss (Loucks et al., 2012).

Figure 3.1. Surface folds and faults mapped in Clearfield County highlights the structual complexity of the area. The green outline illustrates the location of the 3D seismic data set used by Bowers (2014) and Roberts (2013) in relation to the study well (red star). The Chestnut Ridge Anticline terminates within the data set, while stike-slip faults terminate two miles south of data set (Bowers, 2014).

Figure 3.2. Map of reactivated basement structures and blind cross-stuctural discontinuities in relation to Clearfield County. The map illustrates the area of missing Union Springs/lower Marcellus and Oriskany no-sand area that were interpreted to be topographic highs, and erosion resulting from uplift associated with block displacement. It is believed that anticlines, such as the Chestnut Ridge Anticline, were active during deposition of the Marcellus Formation, and the Marcellus demonstrated thickening in the hinges of these anticlines (Lash and Engelder, 2011). The cross-structural discontinuities: L-A = Lawerenceville-Attica; T-MU = Tyrone-Mount Union; $\mathrm{H}-\mathrm{G}=$ Home-Gallistzin, $\mathrm{B}-\mathrm{B}=$ Blairsville-Broadtop, $\mathrm{P}-\mathrm{W}=$ Pittsburgh-Washington (modified from Lash and Engelder, 2011).

Figure 3.3. Onondaga and Marcellus isopach maps created by Boyce (2010) and Yanni (2010). The Onondaga Limestone ispach revealed a thick, topographic high to the east that was interpreted to be a shelf-break environment. The topography of the Onondaga influenced the depositon of the Marcellus Formation. It was interpreted that bathemetric lows were more favorable for organic production and preservation (Boyce, 2010, and Yanni, 2010).

Figure 3.4. A contour map of the average ash ages for the basal unit of the lower Marcellus. The ash ages are oldest in the western distal part of the basin and become younger to the east. This contradicts the Acadian foreland basin fill model, which assumes that sediments become younger from east to west. Clearfield County, specifically ECA' s Coldstream \#1MH well, falls on the 392 Ma contour line (Parrish, 2013).

Figure 4.1. Workflow developed by Wang and Carr (2012) to classify shale lithofacies from core data in the Marcellus Formation.

Figure 5.1. This schematic identifies the data being used in this study and acts as an outline for the results section. 
Figure 5.2. Summary of core description for the Huntersville Chert, Onondaga, and Lower Marcellus Formations, extending from 7130 to $7175.65 \mathrm{ft}$. in core depth, and from 7116.50 to $7162.15 \mathrm{ft}$. in log depth.

Figure 5.3. Summary of core description for the top part of the Lower Marcellus, Purcell Limestone, and bottom part of upper Marcellus, extending from 7080 to $7130 \mathrm{ft}$. in core depth, and from 7066.50 to $7116.50 \mathrm{ft}$. in log depth.

Figure 5.4. Summary of core description for the top part of the upper Marcellus and Mahantango Formation, extending from 7030 to $7080 \mathrm{ft}$. in core depth, and from 7016.50 to $7066.50 \mathrm{ft}$. in log depth.

Figure 5.5. Summary of core description for the remainder of the cored Mahantango Formation, extending from 7002 to $7030 \mathrm{ft}$. in depth, and from 6988.50 to $7016.50 \mathrm{ft}$. in log depth.

Figure 5.6. Visual image of the large calcareous concretions found in the lower (left) and upper (right) Marcellus. The concretion on the right is also pyritic and is associated with calcite filled fractures that cross cut the pyritic bands. The concretion in the lower Marcellus has calcite lenses on its upper and lower limits. Furthermore, due to the large size of these calcareous concretions, they are noted in the gamma ray response.

Figure 5.7. This figure shows the Purcell Limestone as well as the upper and lower Marcellus contacts (red dashes). The Purcell limestone consists of an allochemical, argillaceous limestone interval, with abundant pyrite, microfossils, and moderate bioturbation, that is bounded above by a calcareous shale interval.

Figure 5.8. This image illustrates the glauconitic, siliceous shale located between the Onondaga Limestone and Huntersville Chert (red dashes).

Figure 5.9. Mineralized, vertical fractures are the most abundant fracture type. They are typically filled with calcite and associated with calcareous concretions and the more calcareous zones.

Figure 5.10. Thin-section images of the lower Marcellus. LM-2 (bottom) shows a darker, more siliceous and organic-rich shale, with silicified algal cysts, thin laminations, silt size quartz grains, and a TOC of 8.25 wt. \%. LM-5 (top) is shale located in the top part of the lower Marcellus. It is lighter and less organically-rich (TOC of $4.38 \mathrm{wt} . \%$ ), with more carbonate and clay content. Laminations are larger with variable amounts of silt, carbonate, and clay, and scattered skeletal fragments and silt filled burrows. (Sample ID used in table of XRD and TOC results, see appendix). Images $\mathrm{A}, \mathrm{B}$, and $\mathrm{C}$ are of a 30 - $\mu$ m-thick portion of thin-section, while image $\mathrm{D}$ is a view of the ultra-thin portion designed to reveal silt grains. Image $\mathrm{B}$ is a view of image A under epifluorescent light to show induced fractures. Image A and B are taken under a resolution of $0.5 \mathrm{~mm}$, while Image $C$ and $D$ are taken under a finer resolution of $0.1 \mathrm{~mm} \ldots \ldots \ldots . .58$ Figure 5.11. Thin-section images of the upper Marcellus LM-8 (bottom) and LM-11(top). Overall these thin-sections consist of more clay and lower silt and organic matter than the lower Marcellus. LM-8 shows a darker, more siliceous and organic-rich shale, with calcified algal cysts and compacted clay filled burrows. TOC is $7.28 \mathrm{wt.} \%$. LM-5 is a gray calcareous shale that contains abundant skeletal fragments of ostracods and brachiopods. TOC is low at 2.33 wt. 
$\%$, with image $\mathrm{C}$ showing a color contrast that is indicative of change in organic material. (Sample ID used in table of XRD and TOC results, see appendix). Images A, B, and C are of a $30-\mu$ m-thick portion of thin-section, while image $\mathrm{D}$ is a view of the ultra-thin portion designed to reveal silt grains. Image $B$ is a view of image $A$ under epifluorescent light to show induced fractures. Image A and B are taken under a resolution of $0.5 \mathrm{~mm}$, while Image $C$ and $D$ are taken under a finer resolution of $0.1 \mathrm{~mm}$.

Figure 5.12. Thin-section images of Mahantango and Onondaga Formations. The Onondaga, ON-1 (bottom) is a massive skeletal packstone that has been recrystallized. Calcite is the dominant mineral and it fills fractures and makes up the majority of the matrix. Image A shows a possible burrow that is cross-cut by a healed, mineralized fracture. The Mahantango, MAH-15 (top) is gray shale, with moderate clay and silt. Silty laminations are present as well as potentially compacted clay burrows and illite blebs. (Sample ID used in table of XRD and TOC results, see appendix). Images $\mathrm{A}, \mathrm{B}$, and $\mathrm{C}$ are of a 30- $\mu$ m-thick portion of thin-section, while image $\mathrm{D}$ is a view of the ultra-thin portion designed to reveal silt grains. Image $\mathrm{B}$ is a view of image A under epifluorescent light to show induced fractures. Image A and B are taken under a resolution of $0.5 \mathrm{~mm}$, while Image $C$ and $D$ are taken under a finer resolution of $0.1 \mathrm{~mm}$

Figure 5.13. PANalytical $X^{\prime}$ Pert HighScore Plus software matching raw peaks to mineral patterns based on the user defined mineral list. Mineral weight percentages for this sample (green box) contains 3\% pyrite, 39\% illite, 1\% dolomite, $52 \%$ quartz, and $4 \%$ calc ite.

Figure 5.14. The graph illustrates the mineral weight percentages by depth from the XRD results for quartz, calcite, dolomite, pyrite, and clay. Quartz also includes plagioclase and K feldspars.

Figure 5.15. The graphs of the lower (bottom) and upper (top) Marcellus illustrates the minimum, maximum, and average weight percentages for quartz, calcite, dolomite, pyrite, clay, and TOC. Mineralogical comparison between the units shows that the lower Marcellus on average has higher quartz and TOC, with lower calcite and pyrite. The average clay weight percent is relatively equal but the minimum and maximum values for clay in the lower Marcellus are less, which is cons istent with core and thin-section interpretation.

Figure 5.16. The ternary diagrams illustrate recalculated XRD clay, quartz, and carbonate percent relative to gamma ray (GR) response for the lower (left) and upper (right) Marcellus. Quartz is combined with the small percent of plagioclase and $\mathrm{K}$ feldspars, while carbonate consists of both calcite and dolomite. These diagrams show that the mineralogy between the lower and upper Marcellus are fairly similar, with the lower Marcellus having slightly more quartz and higher GR response than the upper Marcellus.

Figure 5.17. Relative clay XRD data determined from the total clay weight percent. Illite and mica are abundant and decrease upwards, while chlorite increases in percent upwards. Only a small percent of mixed layer clay is found in the upper Marcellus at a log depth of $7086 \mathrm{ft}$......68 Figure 5.18. Stochastic Mineralogical model generated in the Statmin module in PowerLog by Shuvajit Bhattacharya. A statistical multi-mineral solution was obtained using 4 different well logs: core GR, corrected neutron porosity, corrected bulk density, and the Umaa log. The output 
solution (Track 7) is comprised of 8 log curves: quartz, smectite, illite, calcite, dolomite, kerogen, pyrite, and bulk volume of water.

Figure 5.19. Production index verse vitrinite reflectance data graph illustrates that the 5 Ro samples fall within the dry gas zone, which is indicative of thermally post-mature rocks. 71

Figure 5.20. Hydrogen potential verse TOC weight percent graph shows a low hydrogen index, which is dry gas prone and indicative of type IV kerogen.

Figure 5.21. Spectral core GR of the Onondaga, lower Marcellus, Purcell Limestone, and the bottom part of the upper Marcellus compared to $\mathrm{Th} / \mathrm{K}$ curves, $\mathrm{Th} / \mathrm{U}$ curves, individual curves of $\mathrm{K}$, Th, and $\mathrm{U}$, as well as log and core derived TOC for comparison to the $\mathrm{U}$ curve. .74

Figure 5.22. Spectral core GR log of the upper Marcellus and lower part of the Mahantango Formation compared to $\mathrm{Th} / \mathrm{K}$ curves, Th/U curves, individual curves of $\mathrm{K}$, Th, and $\mathrm{U}$, as well as $\log$ and core derived TOC.

Figure 5.23. The cross-plot of $\mathrm{Th}$ and $\mathrm{K}$ for the cored interval shows relative clay type. For the Onondaga, Marcellus and Mahantango units the clay type ranges from illite to smectite, with a majority of the points concetrated on the reference line between mixed layer clay and illite. .....76 Figure 5.24. The cross-plot of $\mathrm{Th} / \mathrm{K}$ against $\mathrm{Th} / \mathrm{U}$ illustrates the clay type in relation to redox potential for the Onondaga, Marcellus, and Mahantango formations. This plot is consistent with clay type seen in Figure 5.23, with most of the data points concentrated around the illite to mixed-layer clay range. The Marcellus Formation (blue square) is a more reducing environment, which is expected of a shale deposited during anoxic water conditions. The other formations, especially the Mahantango, were depositioned in a more oxygen rich environment..................77

Figure 5.25. This color-coded facies crossplot shows the cutoff values for Ingrain' $s$ CoreHD ${ }^{\circledR}$ facies classification for the whole Coldstream \#1MH core. The colors correspond to different color-coded facies that are selected based on PEF and RHOB values. The two black reference lines correspond to pure minerals of quartz and calcite, while the orange lines correspond to pure minerals of smectite and illite. Facies organic content is related to RHOB values, given that higher organic content will have a lower bulk density.

Figure 5.26. $P E$ values for different minerals. Knowledge of $P E$ values for different minerals is important for the interpretation of Ingra in' s Core HD Facies.. 79

Figure 5.27. Core gamma-ray (GR) (left), CoreHD ${ }^{\circledR}$ facies log (middle), and CoreHD ${ }^{\circledR}$ facies (top-right) and population density (bottom-right) crossplots for the lower Marcellus interval. For the section of high core GR (7,150 to $7155 \mathrm{ft}$.), the pink color-coded facies dominates with the blue facies being associated with calcareous pyritic concretions. The gray color is associated with miss ing core.

Figure 6.1. Criteria for lithofacies prediction for the Coldstream core. Core data included XRD, TOC, spectral core GR and visual descriptions.

Figure 6.2. Lithofacies descriptions for organic-rich siliceous shale (top) and organic-rich mudstone (bottom) .88

Figure 6.3. Lithofacies descriptions for gray siliceous shale (top) and gray mudstone (bottom). 
Figure 6.4. Lithofacies descriptions for calcareous shale (top) and limestone (bottom).

\section{LIST OF TABLES}

Table 2.1. Four of the five ash samples from the Clearfield core were analyzed by Parrish (2013). The samples were radiometrically dated using U-Pb zircon geochronology (modified from Parrish, 2013). Radiometric dates were older when compared to the calibrated timescale predicted by Kaufman (2006), which was established from biostratigraphic data.

Table 4.1. The table on the top left lists the core analysis data from Core Labs that will be evaluated for this study.

Table 4.2. The table on the bottom left lists the deliverables from the X-ray CT scan performed by Ingrain in Houston, TX.

Table 4.3. The stratigraphy for the Coldstream Affiliates Well, with core/log depth as well as the thickness for each stratigraphic interval. The core /log depth correction was approximated as 13.50 feet $(4 \mathrm{~m})$ subtracted from core depth, which was determined by correlating log gamma to spectral core gamma ray.

Table 5.1. The table above shows the fracture types and intensity for the cored well. In the Marcellus, the fracture intensity is higher in the upper Marcellus, while the Onondaga has the highest fracture intensity of all the formations. 


\section{Introduction}

The Middle Devonian Marcellus Formation is a very important source rock and hydrocarbon reservoir in the northeastern United States, predominately found in Pennsylvania, southwestern New York, West Virginia, eastern Ohio, and western Maryland. Pennsylvania is the center for unconventional Marcellus Formation shale-gas exploration and production. The Marcellus Formation is not a recent discovery as it has been known as a source rock for the Upper Devonian and Lower Mississippian conventional reservoirs for many years. In 2004, the Middle Devonian Marcellus Formation became a major drilling target for horizontal drilling and hydraulic fracturing, when Range Resources Corporation completed the first horizontal shale-gas well in Washington County, Pennsylvania. Currently, the Marcellus Formation underlies an area of approximately 95,000 $\mathrm{mi}^{2}$ (Carter et al., 2011) and could contain 141 trillion cubic feet (TCF) of unproved technically recoverable gas (U.S. EIA, 2012).

Because the modern Marcellus Formation shale play has such potential as a significant gas reservoir for the United States, an abundance of research has gone into developing this resource through correlating wireline logs, interpreting structural properties via geophysical techniques, and analyzing core data for information on mineralogy, porosity, permeability, total organic carbon (TOC), and fracture systems. Recently, research regarding mudstone facies diversity, specifically in organic-rich black shale through core analysis has been a major focus in the industry. The heterogeneity of shale has been recognized and documented for some time (Milliken et al., 2012), however, the effects of lithology variation and changes in depositional environment as well as different structural controls in relation to reservoir quality is not widely researched in shale analogs. Thus, more advanced core and well log analysis techniques have 
surfaced in recent years to identify lithofacies and depositional sequences through integration of core and log data.

\subsection{Research Significance and Objective}

The general lithology and sequence stratigraphy of the Marcellus Formation greatly affects the success of exploration and production within the natural gas industry. Efforts have been made to better understand mudstone diversity in organic-rich black shale, since minute changes in depositional environment and sediment influx can have a large impact on composition and diagenesis of these shale members (Carter et al., 2011). Identifying the variation in black shale is the key to understanding reservoir characterization and for the ongoing development of the Marcellus Formation gas play. Analysis of physical core data taken from cored wells is the primary method for determining variation in lithofacies for fine-grained rocks. Recently more advanced methods, such as digital rock physics (DRP), are being used to predict lithofacies and associated trends in porosity, permeability, and organic content. One major objective is to establish a comprehensive sequence-stratigraphic framework by recognizing stacking patterns of lithofacies and depositional sequence boundaries that are developed from the integration of core and log data.

In this study, I analyzed the physical whole core data from a well in Clearfield County, Pennsylvania, and calibrated this data to the spectral core gamma-ray (GR) $\log$ for the cored well. My goal is to better understand the Marcellus Formation in terms of its lithology, sequence boundaries, mineralogy, and organic content through direct measurements of the core material. Developing a method to relate these attributes to depositional and diagenetic environment, and subsequently understanding the stacking patterns of lithofacies, with emphasis on condensed sections (CSs) (Abouelresh and Slatt, 2012), in the cored interval will be a major focus of this study. A sequence-stratigraphic model or interpretation will be integrated with data from core 
description, thin-section analysis, geochemical methods, digital rock physics, and spectral core GR.

\subsection{Study Area}

The study area is in Clearfield County, Pennsylvania (Fig. 1.1). Geologically, Clearfield County is located in the Appalachian plateau geological provenance of the central Appalachian basin. In relation to the Marcellus play, Clearfield County is located between two main producing areas, southwestern and northeastern Pennsylvania in an area of organic thickness ranging between 75 to 100 feet (23 to $31 \mathrm{~m})$.

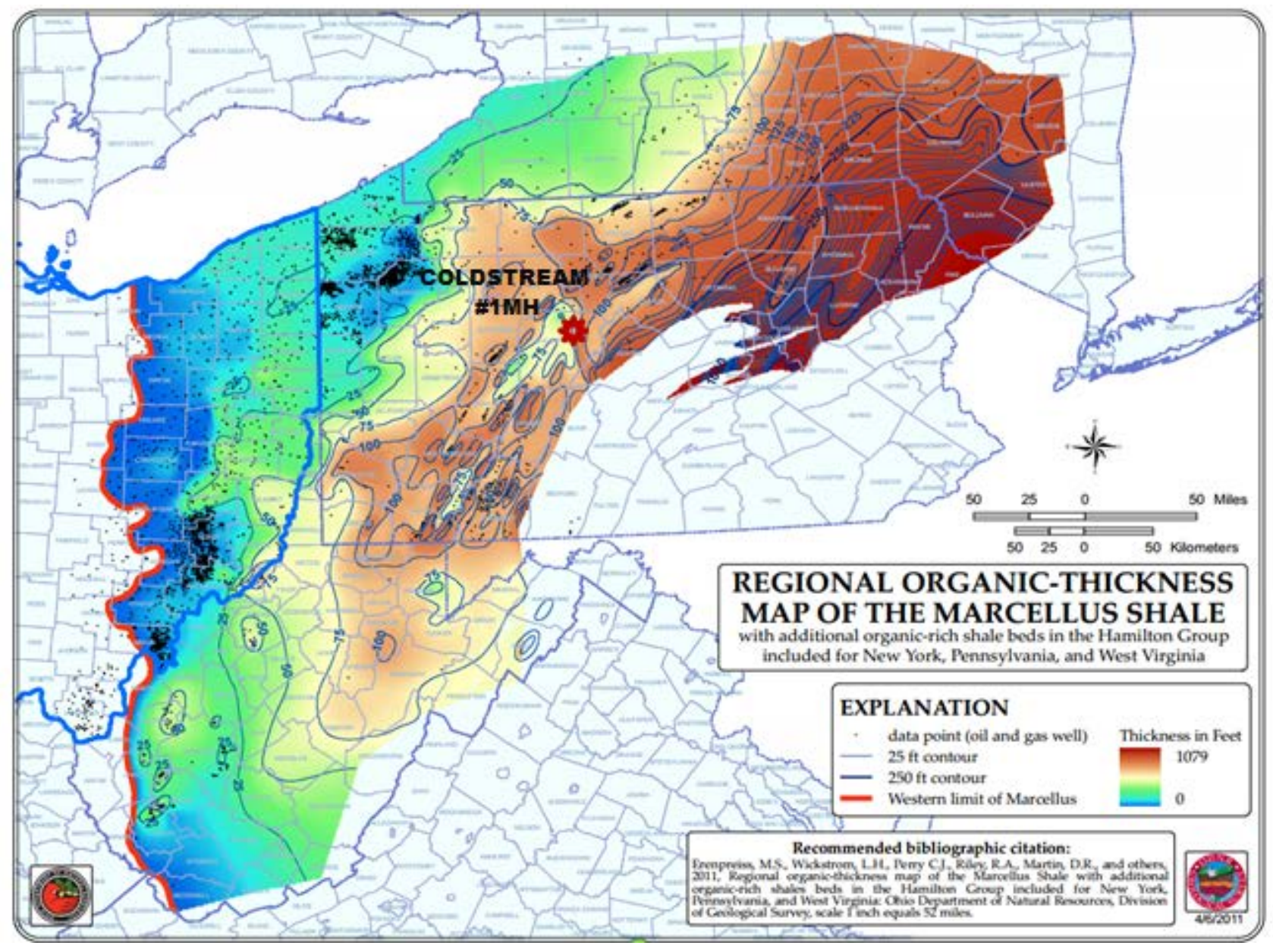

Figure 1.1. The Study Area is in Clearfield County, Pennsylvania. It is located in the Appalachian plateau geological provenance in the central Appalachian basin. The Cold Stream Affiliates \#1MH (red well symbol) is the cored well analyzed in this study. Map Modified from Erenpreiss, et al., (2011). 


\section{Geologic Background}

\subsection{Geologic Setting}

The Appalachian basin formed during the Late Ordovician Taconic, when the Potomacmagmatic arcs and subsequent Theic elements were obducted onto the eastern continental margin of Laurentia (Faill, 1997). The once broad carbonate shelf that existed on the margin of Laurentia was drowned with siliciclastic sediments. The resulting continental rise formed the Taconic highlands, which acted as a topographic barrier permanently separating Theia and the Appalachian basin (Faill, 1997).

The Appalachian basin is an intracontinental foreland basin trending northeast to southwest. A foreland basin is a product of tectonic deformational loading or thickening of crust along the orogen, and is a consequence of overthrusting and folding (Ettensohn, 1987). The foreland basin is located on the cratonic side of the orogen due to regional isostatic adjustment to the load by the lithosphere (Ettensohn, 1987). In addition to the foreland basin, a peripheral bulge is also generated in response to the increasing deformational load. In the beginning, subsidence is rapid and sediment influx is low, but as tectonic thrusting slows more sediment accumulates in the basin. Overtime the load grows causing bulge-basin migration and uplift towards the craton in the west, which eventually generated localized unconformities and subsequent shallow-water carbonates (Ettensohn and Carlton, 2002).

Following the Taconic orogeny and initial formation of the Appalachian basin, the Acadian orogeny formed the Appalachian orogen (Faill, 1997). The Acadian orogeny resulted from oblique convergence or major transcurrent movement along a large strike-slip fault, which represents the zone of convergence between Laurentia (North America) and the Avalonian terranes (Ettensohn, 1987). One or more of the Avalonian terranes accreted with the eastern margin of Laurentia, most likely beginning in the late Early Devonian and extending into the 
Early Mississippian. The southwesterly procession of convergence during the Acadian orogeny developed some of the best-known and thickest delta complexes in the Appalachian basin (Ettensohn, 2004).

The Acadian delta complex is categorized into two deltas, the Catskill delta of Middle to Late Devonian age, and the Price-Rockwell (Pocono) delta of Late Devonian to Early Mississippian in age (Milici and Swezey, 2006; Ettensohn, 2004). The Catskill delta complex was responsible for depositing large volumes of siliciclastic sediments into the basin (Ryder et al., 2012). The formation and distribution of black shale in the foreland basin is the result of subsidence, rise in base-level, and reactivation of basement structures that initiated a transgressive sequence as dark shale started to replace carbonate facies (Ettensohn, 1985, Lash and Engelder, 2011). Because of the equatorial conditions, organic productivity was high relative to sediment influx, where bottom waters demonstrated anoxic conditions (Castle, 2001; Ettensohn, 1987).

During the Middle Devonian (385 Ma), the paleolatitude of the central Appalachian basin was in the southern hemisphere near the equator, between $15^{\circ} \mathrm{S}$ to $30^{\circ} \mathrm{S}$ (Scotese and McKerrow, 1990). The paleoclimate was in an equatorial climate zone resulting in tropical wet and dry zones, with seasonally restricted rainfall and high evaporation rates (Woodward et al., 1973). A reconstruction of the Middle Devonian paleogeography (Fig. 2.1) illustrated the Appalachian basin as a restricted epicontinental seaway, with the Acadian orogen to the east and the Cincinnati arch (peripheral bulge) to the west (Blakey, 2010). 


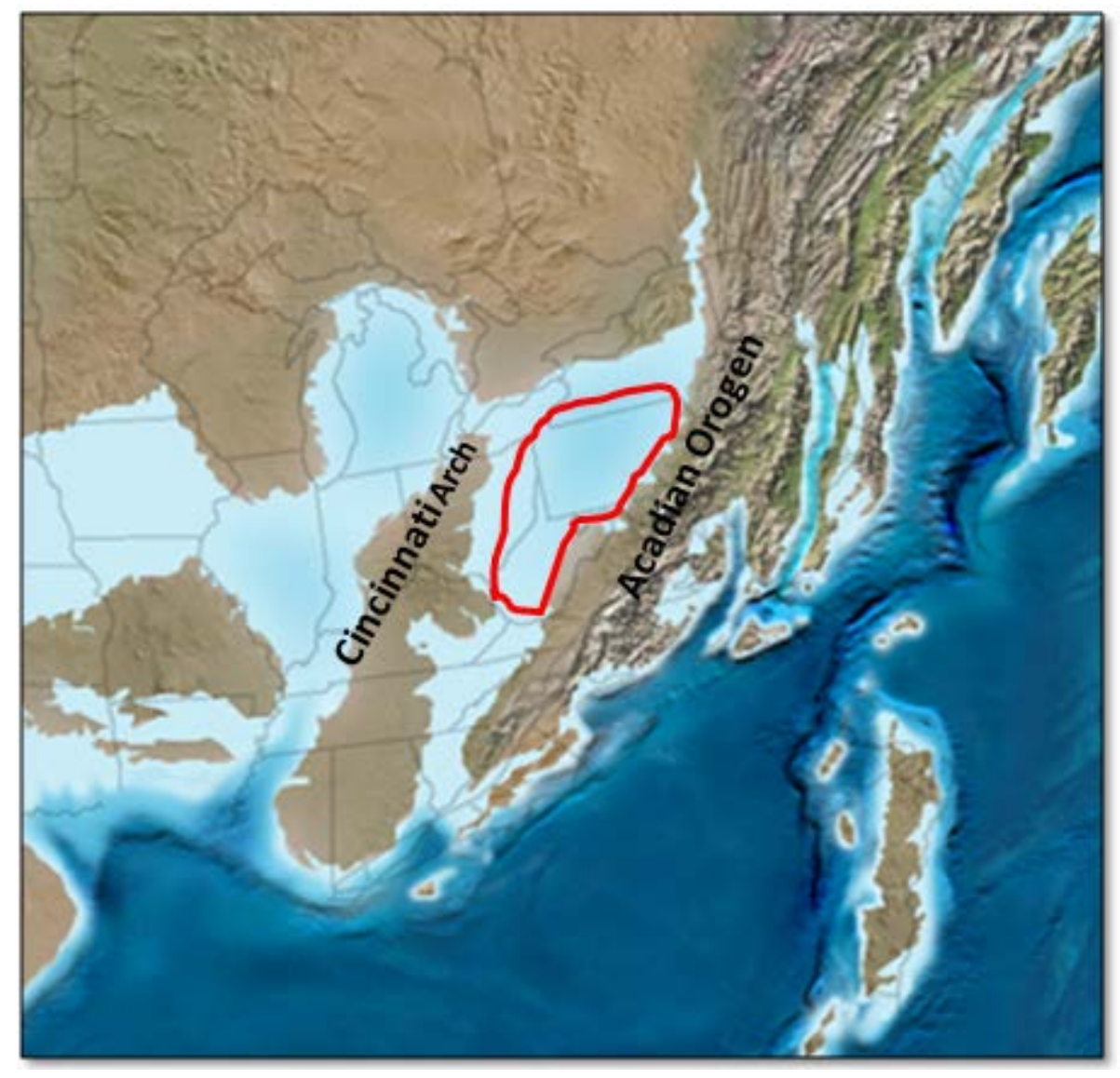

Figure 2.1. Reconstruction of Middle Devonian (385 Ma) paleogeography. Northern Appalachian basin identified (red) with Acadian orogen in the east and the Cincinnati arch to the west (modified from Blakey, 2010).

\subsection{Depositional Environment}

The Catskill delta complex was responsible for the deposition of thick clastic sequences in both the proximal and distal parts of the Appalachian basin (Ettensohn, 2004; Sageman et al., 2003). These deposits extended from central New York and Pennsylvanian into Ohio, and south along the Appalachian mountains through Virginia (Ettensohn, 2004; Milici and Swezey, 2006). The sediments were deposited in a coarsening upwards sequence, and thin dramatically westward into Ohio. The Catskill delta sediments were thickest in eastern Pennsylvania at 
12,000 feet $(3,658 \mathrm{~m})$, and at its thinnest around 400 feet $(122 \mathrm{~m})$ in western Ohio (DeWitt et al., 1975, Milici and Swezey, 2006).

Phases of thrust loading, during the Acadian orogeny, deposited organic-rich black shale and overlying, coarser sediments in cycles (Ettensohn, 1987; Castle, 2001). Harper (1999) and J.W. Castle (2001) categorized these cycles into five major facies tracts for the Catskill delta complex (Fig. 2.2). These five time-transgressive magnafacies (facies I - V) prograded into the foreland basin from the Acadian mountains in the east (Harper, 1999; Milici and Swezey, 2006). Facies I consist of "dark-gray to black, somewhat calcareous, pyritic, sparsely fossiliferous shale" (Harper, 1999). Facies I, organic-rich black gas shale, grades laterally and vertically eastward into coarser grained siliciclastics (Facies II - V). The Marcellus Formation is consistent with the lowermost of the black shale tongues in the depositional cycles of the Catskill delta complex (Dennison, 1985; De Witt et al., 1993; Harper, 1999; Milici and Swezey, 2006).

Ettensohn (1985) believed the black shale of the Marcellus Formation had a greater westward migration as a response to basin infilling due to the prograding Catskill delta (Ettensohn, 1985; Castle, 2001). Conditions were changing during facies propagation from aerobic, dysaerobic, and anaerobic, which resulted in significant variations in the Marcellus Formation (Ettensohn, 1985). It is thought that anaerobic conditions were better suited for the preservation of organic matter since thermohaline water stratification inhibited vertical circulation (Ettensohn, 1985; Castle, 2001). Times of sea-level rise lead to sediment starvation and increased organic matter due to a higher preservation potential and enhanced production from episodic mixing of bottom water. During times of regression, sediment became diluted due to an increase in clastic influx and water column mixing (Sageman et al., 2003). Furthermore, reactivated basement structures played a large role in sedimentation and organic 
matter production due to block displacement creating bathymetric highs and lows (Lash and Engelder, 2011).

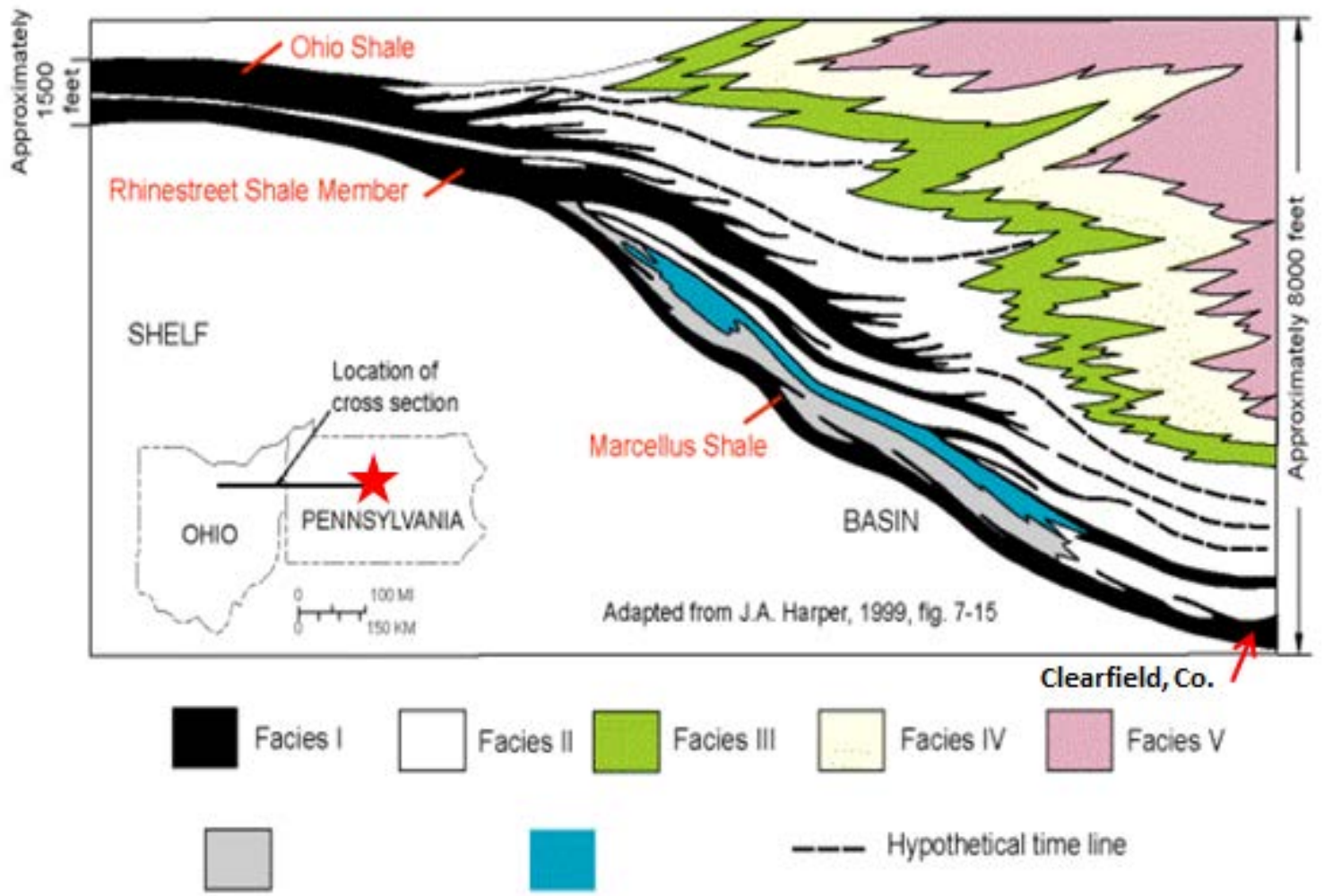

Undifferentiated upper Middle Devonian rocks

Tully Limestone

Figure 2.2. Regional facies model of the Acadian Clastic wedge illustrating the five magnafacies of the Appalachian basin. Facies I: dark-gray to black, organic-rich, basinal marine shale. The cross section is from Ohio to central Pennsylvania, with the red star showing the approximate location of Clearfield County, PA, putting the Cold Stream Affiliates \#1MH well in the thicker part of the basin, where sediments appear to be associated with shallower water facies (modified from Harper, 1999).

\subsection{Stratigraphy}

In western Pennsylvania, the Middle Devonian strata of the Hamilton Group are comprised of the older Marcellus Formation and bounded above by the younger Mahantango 
Formation (Fig. 2.3). The Hamilton Group belongs to the Eifelian and Givetian stages of the Middle Devonian (385 Ma) (Ryder et al., 2012). The Marcellus Formation lies conformably above the Onesquethaw Group, which consists of the Onondaga Limestone, Huntersville Chert, and Needmore Shale (Fig. 2.3) (Wrightstone, 2009).

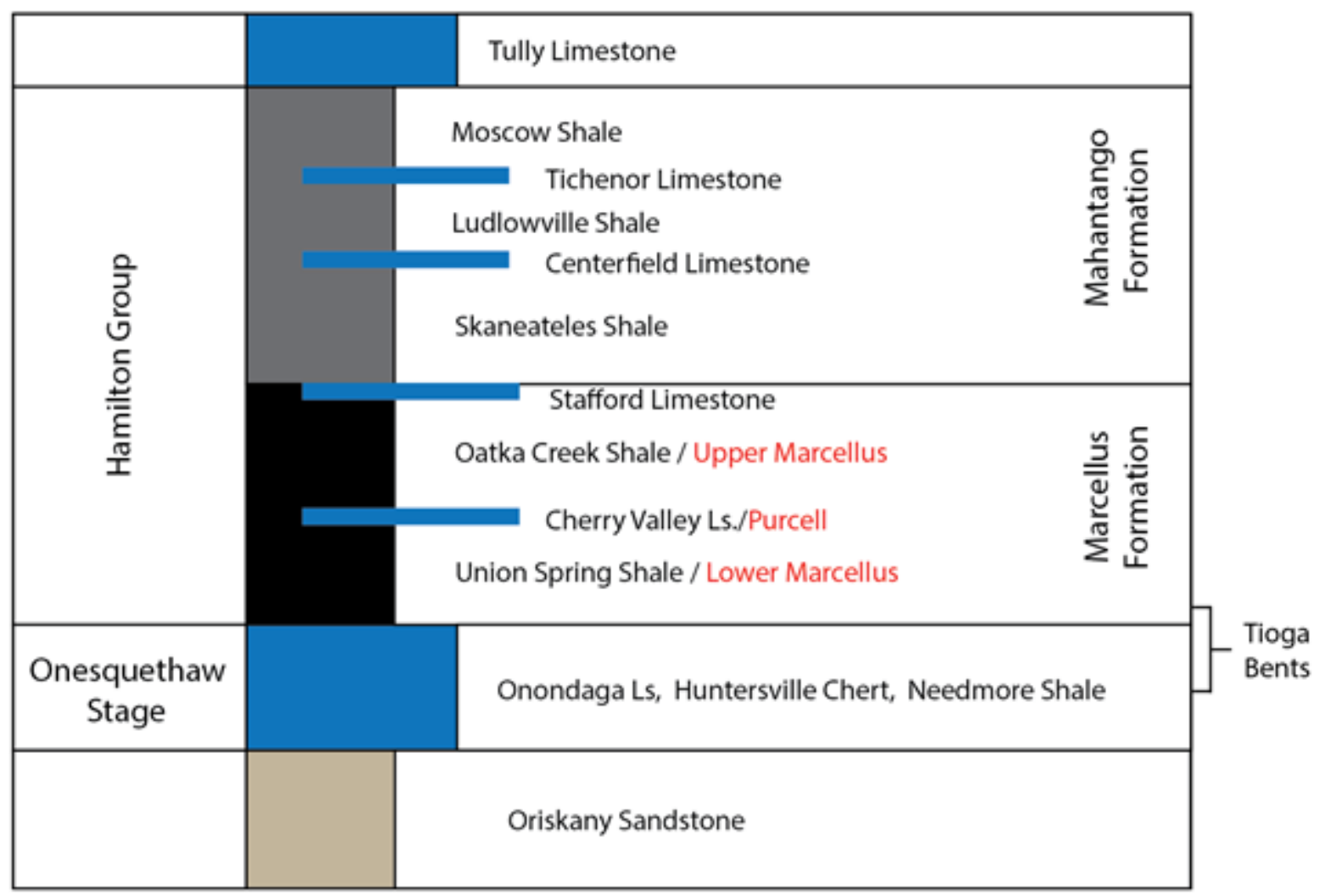

Figure 2.3. This figure illustrates the stratigraphy of the Lower and Middle Devonian in the Appalachian Basin. In this study, the stratigraphic nomenclature used for the Marcellus Formation is highlighted in red (modified from Wrightstone, 2009).

\subsubsection{Onondaga Limestone}

The Onondaga Limestone underlies the Oriskany Sandstone and is overlain by the Marcellus Formation. The Onondaga Limestone of the Onesquethaw Stage (Fig. 2.3) is located in western New York, parts of Pennsylvania, and northern West Virginia. In Pennsylvania, Onondaga equivalent limestone units transition in a southerly direction into the Needmore Shale 
in western Maryland, northern Virginia, and West Virginia. The Needmore Shale then grades into the Huntersville Chert in western Pennsylvania and West Virginia (Milici and Swezey, 2006).

The Onondaga Limestone is believed to be deposited in a shallow epicontinental sea during the early to middle Eifelian time, approximately between $391.9 \pm 3.4$ and $390 \pm 0.5 \mathrm{Ma}$ (Fig. 2.4)(Kohl et al., 2014, Kaufman, 2006). It represents a broad carbonate bank, approximately 220 feet $(67 \mathrm{~m})$ thick, which includes a variety of facies ranging from a light to dark brownish gray cherty or argillaceous limestone, to fossiliferous grainstone and biohermal reefs, to black calcareous mudstone. (Parrish, 2013, Kohl et al., 2014, Fettke, 1961). The Onondaga pinnacle reef system consisted of tropical type fossils, such as corals, brachiopods, corals, crinoids, trilobites, and trace fossils in the form of burrowing (Sexton, 2011, Lindholm, 1969, Kohl et al., 2014). In the southeastward direction, the shallow water facies, more common in northeastern Pennsylvanian and New York, thins in into a deeper water facies characterized by argillaceous wackestone and micrite limestone interbedded with calcareous shale (Kohl et al, 2014, Parrish, 2013). 


\begin{tabular}{|c|c|c|c|c|c|c|c|c|c|c|}
\hline & $\begin{array}{l}\text { Devoniz } \\
\text { Timesca }\end{array}$ & & $\begin{array}{l}\text { Sequence } \\
\text { Stratigraphy }\end{array}$ & & Str & atigraphic Nome & enclature & & & \\
\hline \multirow[t]{7}{*}{ (Ma) } & \multirow{10}{*}{ 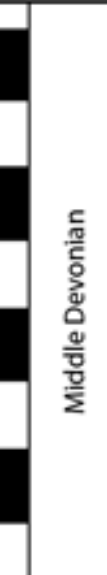 } & \multirow{6}{*}{$\frac{\text { c }}{\frac{\text { co }}{5}}$} & $\begin{array}{l}\text { Third Order } \\
\text { Sequence }\end{array}$ & $\begin{array}{c}\text { NY } \\
\text { ver Straeten } \\
(2004,2007)\end{array}$ & $\begin{array}{c}\text { Southem PA } \\
\text { Milici and } \\
\text { Sweezy (2006) }\end{array}$ & $\begin{array}{c}\text { Central PA } \\
\text { ver Straeten } \\
(2007)\end{array}$ & $\begin{array}{l}\text { Kohl et al } \\
\text { (2014) }\end{array}$ & \multicolumn{2}{|c|}{$\begin{array}{l}\text { Nomenclature } \\
\text { Used in this } \\
\text { Study }\end{array}$} & \multirow{6}{*}{$\begin{array}{c}\text { Taghanic } \\
\text { Unconformity }\end{array}$} \\
\hline & & & Giv-4 & Tully Fm. & \multirow{4}{*}{$\begin{array}{c}\text { Mahantango } \\
\text { Fm. }\end{array}$} & \multirow{4}{*}{$\begin{array}{c}\text { Mahantango } \\
\text { Fm. }\end{array}$} & \multirow{4}{*}{$\begin{array}{c}\text { Mahantango } \\
\text { Fm. }\end{array}$} & \multirow{4}{*}{\multicolumn{2}{|c|}{$\begin{array}{c}\text { Mahantango } \\
\text { Fm. }\end{array}$}} & \\
\hline & & & Giv-3 & Moscow Fm. & & & & & & \\
\hline & & & Giv-2 & Ludlowville Fm. & & & & & & \\
\hline & & & Giv-1 & Skaneatles Fm. & & & & & & \\
\hline & & & Eif-Giv & Oatka Creek Fm & Marcellus & Unnamed Mbr. & Oatka Creek Mbc. & Marcellus & Upper & \\
\hline & & & & 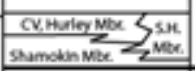 & $\mathrm{Fm}$. & \begin{tabular}{|l|} 
Punced Mbc \\
Shamokin Mbc
\end{tabular} & 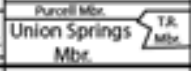 & $\mathrm{Fm}$. & Lower & $\leftarrow$ Purcell Mbr. \\
\hline \multirow[t]{3}{*}{390} & & $\frac{c}{10}$ & Eif-2 & \multirow{3}{*}{$\begin{array}{l}\text { Onondaga } \\
\mathrm{Fm} .\end{array}$} & \multirow{3}{*}{ 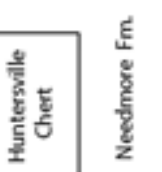 } & Selinsgrowe Mbe. & \multirow{3}{*}{$\begin{array}{c}\text { Onondaga } \\
\text { Fm. }\end{array}$} & \multirow{3}{*}{\multicolumn{2}{|c|}{$\begin{array}{l}\text { Onondaga } \\
\text { Fm. }\end{array}$}} & Tinga B \\
\hline & & $\overline{\bar{\omega}}$ & & & & & & & & \\
\hline & & تَ & Eif-1 & & & $\begin{array}{c}\text { Needmore } \\
\text { Fm. }\end{array}$ & & & & Sub-Onondaga \\
\hline
\end{tabular}

Figure 2.4. Lithologic subdivis ions for the Middle Devonian Eifelian to Givetian Strata from ver Straeten (2004 and 2007), Milici and Sweezy (2006), and Kohl et al. (2014). Calibrated time scale derived from Kaufman (2006) and third order depositional sequences from Brett et al. (2011) and ver Straeten (2007). The stratigraphic nomenclature used in this study is on the far right (modified from Kohl, 2014).

\subsubsection{Tioga K-Bentonites}

The Tioga Bentonite is a regionally distinct marker bed produced by arc magmatism along the Acadian orogen. It is a stratigraphic unit that consists of several thin layers of volcanic ash that can provide radiometric dates to determine depositional rate and chronostratigraphy.

The upper limits of the Tioga ash beds are in the lower part of the Marcellus Formation with its lower limits in the upper part of the Onondaga Limestone or Needmore Shale (Parrish, 2013, Milici and Swezey, 2006, Woodrow et al., 1988). The Tioga ash beds are separated into two groups: Tioga A-G and Tioga MCZ. The Tioga A-G ash beds are located in the Onondaga Formation and lower Marcellus, while the Tioga MCZ ash beds are found in the Onondaga Limestone and Huntersville Chert. The Tioga MCZ cluster is predominately located in parts of Virginia and West Virginia (Parrish 2013, Ver Straeten, 2004). 
The Tioga ash beds in the cored interval are assumed to belong to the A-G cluster (Parrish, 2013). Chantelle Parrish (2013) identified five ashes in the Cold Stream core that were interbedded within an eight feet interval of the lower Marcellus and the upper Onondaga Formation (Fig. 2.6). The ashes were identified by their buff color, mica flakes, and increase pyrite concentration, and were classified as "thinly laminated tuffaceous shale" of varying thicknesses. Four of the five Cold Stream ashes were radiometrically dated by Parrish using U$\mathrm{Pb}$ zircon geochronology (Table 2.1) (Parrish, 2013). However, the radiometric dates determined by Parrish are not in agreement with the calibrated timescale in Figure 2.4. Chronologically, the ash beds dated by Parrish for Clearfield County are older than the dates predicted by Kaufman (2006) for the Middle Devonian. The results of radiometric dating from other wells in the study area suggested that ash beds were deposited diachronously from west to east (Parrish, 2013). 


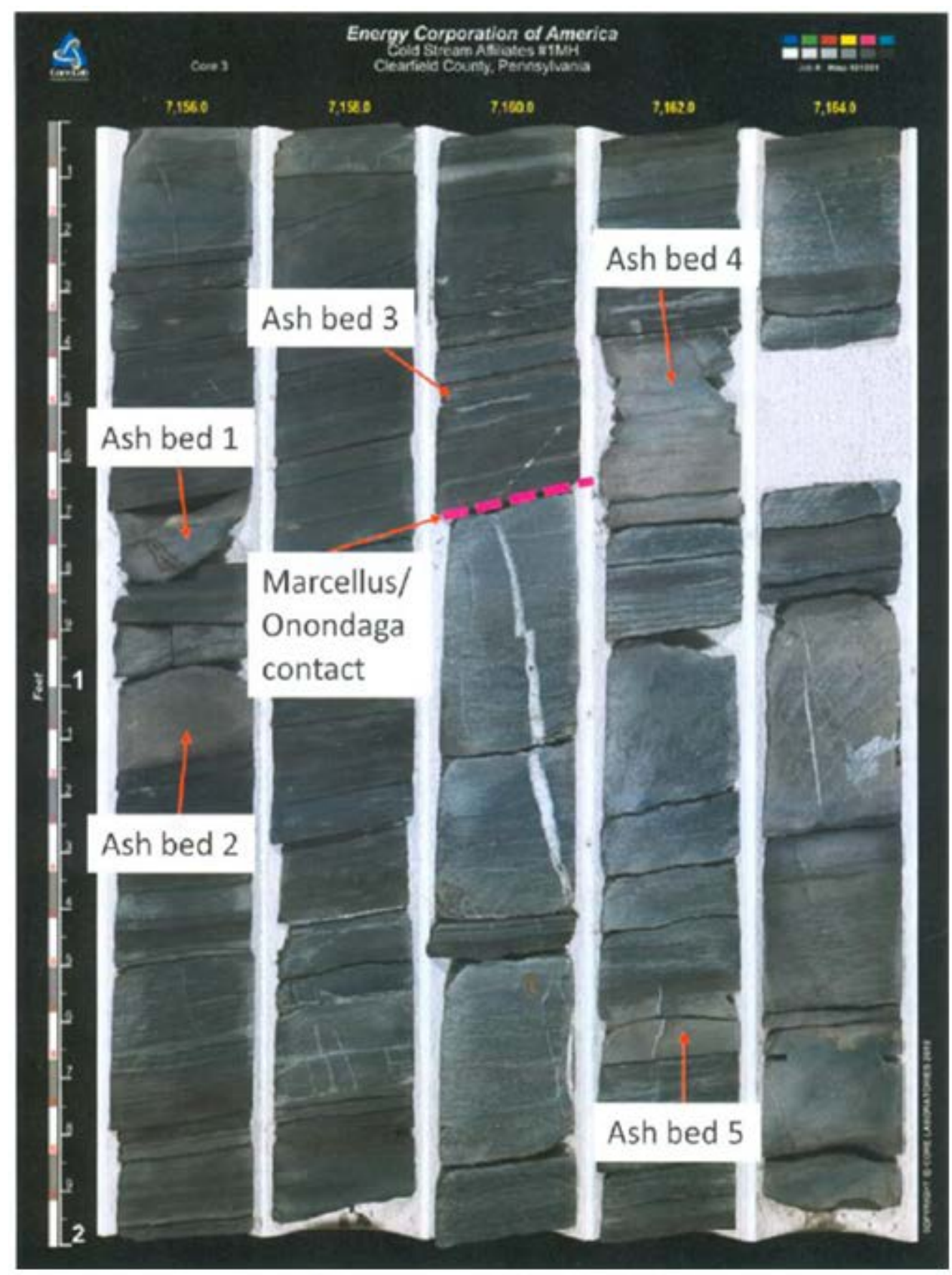

Figure 2.5. ECA Coldsteam \#1MH well core photo from Core Labs with five ash beds that Parrish (2013) identified. Radiometric dates are listed in Table 2.1. The ash beds are recognized by their buff color and visible mica flakes (Parrish, 2013). Besides illustrating the ash beds, this core photo shows Onondaga-Lower Marcellus contact. The contact between the OnondagaLower Marcellus is a sharp, low-angle contact, where argillaceous limestone transitions into a calcareous, black shale that is interbedded with limestone. 


\begin{tabular}{|l|c|c|c|l|l|c|}
\hline $\begin{array}{l}\text { Well Name } \\
\text { County, State }\end{array}$ & $\begin{array}{c}\text { Sample } \\
\text { ID }\end{array}$ & $\begin{array}{c}\text { Ash \# } \\
\text { (depth in ft.) }\end{array}$ & $\begin{array}{c}\text { Ash Thickness } \\
\text { (Inches) }\end{array}$ & $\begin{array}{l}\text { Average } \\
\text { 238 } \mathbf{2 0 6} \text { Pb } \\
\text { Age (Ma) }\end{array}$ & $\begin{array}{l}\text { Concordia } \\
\text { Age (Ma) }\end{array}$ & $\begin{array}{l}\text { \# of zircon } \\
\text { analyses } \\
\text { used in age } \\
\text { calculations }\end{array}$ \\
\hline $\begin{array}{l}\text { Coldstream \#1 } \\
\text { Clearfield, PA }\end{array}$ & Cold1 & $1(7156.7)$ & 1.18 & $394.2 \pm 4.8$ & $394.1 \pm 1.9$ & 10 \\
\cline { 2 - 7 } & Cold2 & $2(7157.2)$ & 1.97 & $391.3 \pm 4.8$ & $390.5 \pm 4.4$ & 13 \\
\cline { 2 - 7 } & Cold4 & $4(7162.4)$ & 3.94 & $393.4 \pm 5.5$ & $392.3 \pm 2.3$ & 9 \\
\cline { 2 - 7 } & Cold5 & $5(7163.5)$ & 0.98 & $396.5 \pm 5.6$ & $396.3 \pm 2.4$ & 8 \\
\hline
\end{tabular}

Table 2.1. Four of the five ash samples from the Clearfield core were analyzed by Parrish (2013). The samples were radiometrically dated using U-Pb zircon geochronology (modified from Parrish, 2013). Radiometric dates were older when compared to the calibrated timescale predicted by Kaufman (2006), which was established from biostratigraphic data.

\subsubsection{Marcellus Formation}

The Marcellus Formation extends across Pennsylvania into eastern Ohio, and is thickest in northeast Pennsylvania at approximately 200 feet $(61 \mathrm{~m})$ (De Witt et al., 1993, Milici and Swezey, 2006). The mudrock stratum of the Marcellus Formation is the lowermost stratigraphic unit in the Hamilton Group and it is the first formation deposited as a result of the Acadian orogeny. Stratigraphic nomenclature varies depending on location in the Appalachian basin. The stratigraphic terminology for the Marcellus Formation is convoluted due to facies variations across the basin and a long history of study. Figure 2.3 illustrates the nomenclature used in this study for the Marcellus Formation: the lower Marcellus, the upper Marcellus, and the Purcell Member.

The lower Marcellus, known as the Union Springs Member or Bakoven Member in New York and the Shamokin Member in central Pennsylvania and northern West Virginia, is located conformably above the Onondaga Formation. Overlying the upper Marcellus is the Purcell Member or equivalent Cherry Valley Limestone, as it is called in New York. In some literature, the Hurley, Cherry Valley, and Berne Member, in overlying succession, are considered to be units within the Oatka Creek Member. However, in central Pennsylvanian and northern West 
Virginia, the Hurley and Cherry Valley members, together, are recognized as the Purcell Member, while the overlying Berne Member is equivalent to the Oatka Creek Member or the upper Marcellus (Fig. 2.4) (Sexton, 2011, Ver Straeten, 2007, Ver Straeten and Brett, 2006, Lash and Engelder, 2011). The upper Marcellus or Oatka Creek Member, in New York, is located stratigraphically above Purcell Member and is overlain by the Mahantango Formation of the Hamilton Group.

The lower Marcellus is believed to be deposited during the late Eifelian time, approximately between $390 \pm 0.5$ and $388.1 \pm 2.6 \mathrm{Ma}$, as suggested by Kaufmann (2006), while Parrish (2013) predicted an earlier deposition between Emsian and Eifelian age. The lower Marcellus/Union Springs Member, in western New York, is described as a highly organic, calcareous, dark-gray to black mudstone containing skeletal lags (Sageman et al., 2003). The lower Marcellus is characterized by high radioactivity, especially at the bottom 20 to 30 feet (6 to $9 \mathrm{~m}$ ), and low density $\left(<2.35 \mathrm{~cm}^{3}\right)$. The overall mineralogy is described as having a lower clay percent with higher quartz, pyrite, and TOC content (Lash and Engelder, 2011).

The carbonate-rich Purcell Member divides the Marcellus into two informal members. It is chronostratigraphically equivalent to the Cherry Valley Limestone and Hurly Member (Fig. 2.4) (Ver Straeten and Brett, 2006). The thickness of the Purcell Member is irregular ranging from less than 10 feet $(3 \mathrm{~m})$ in western New York and west-central Pennsylvania to more than 140 feet $(43 \mathrm{~m})$ thick in northeastern Pennsylvania. The lithology of the Purcell member varies depending on location and overall is known as an interval of bedded and nodular limestone, shale, and siltstone (Lash and Engelder, 2011). In New York, the Hurley Member consists of a medium to gray nodular, micritic limestone horizon that is bioturbated with skeletal debris, while the overlying Cherry Valley Limestone is defined as a medium gray packstone with abundant 
skeletal debris (Sageman et al., 2003). The Purcell Member becomes more arenaceous to the southeast especially near the Pennsylvania Valley and Ridge Province, which was confirmed from an ongoing coring program (Lash and Engelder, 2011).

The upper Marcellus is believed to be deposited during the late Eifelian to early Givetian time (Kohl et al., 2014, Kaufman, 2006). The upper Marcellus, equivalent to the Oatka Creek or Berne Member, is recognized as a medium to dark-gray mudstone with a basal interval of black organic-rich mudstone (Lash and Engelder, 2011, Sageman et al., 2003). The upper Marcellus has occasional carbonate layers, one such layer, called the Halihan Hill bed can be correlated as a small bioclastic limestone interval (Werne et al., 2002). The upper Marcellus is characterized by high radioactivity at the base of the interval, which grades upward into a less radioactivity and higher density interval. The upper Marcellus in comparison with lower Marcellus typically has lower TOC values and higher density (Lash and Engelder, 2011).

\subsubsection{Mahantango Formation}

The Marcellus Formation is bounded above and grades southeastward into the Mahantango Formation in Pennsylvania. Similar to the Marcellus Formation nomenclature varies in the Mahantango Formation due to a long history of study and location in the basin. In western New York, the Mahantango is divided, in ascending order, into the Skaneateles, Ludlowville, and Moscow shale units (Wrightstone, 2009, Lash and Engelder, 2011). The core for this study only encompasses approximately 53 feet of the lower Mahantango Formation, most likely the Skaneateles Shale, which consists of gray to dark-gray mudstone that are moderately organic (Werne et al., 2002). 


\subsection{Sequence Stratigraphy of Study Interval}

Several researchers have documented and published on the sequence stratigraphy of the Marcellus Formation and underlying Onondaga Limestone. This study utilizes the transgressiveregressive sequence stratigraphic terminology outlined in K.M. Bohacs and O.R. Lazar (2010) with approaches similar to what Daniel Kohl et al. (2014) and Charles Ver Straeten, Carlton Brett, and Bradley Sageman (2011) used in their study of the Marcellus Formation. Other research by Gary Lash and Terry Engelder (2011) was also considered in the sequence stratigraphic framework of the cored interval. The fundamental unit of sequence stratigraphy is a depositional sequence, which can be divided into systems tracts and ultimately parasequence sets (Fig. 2.6).

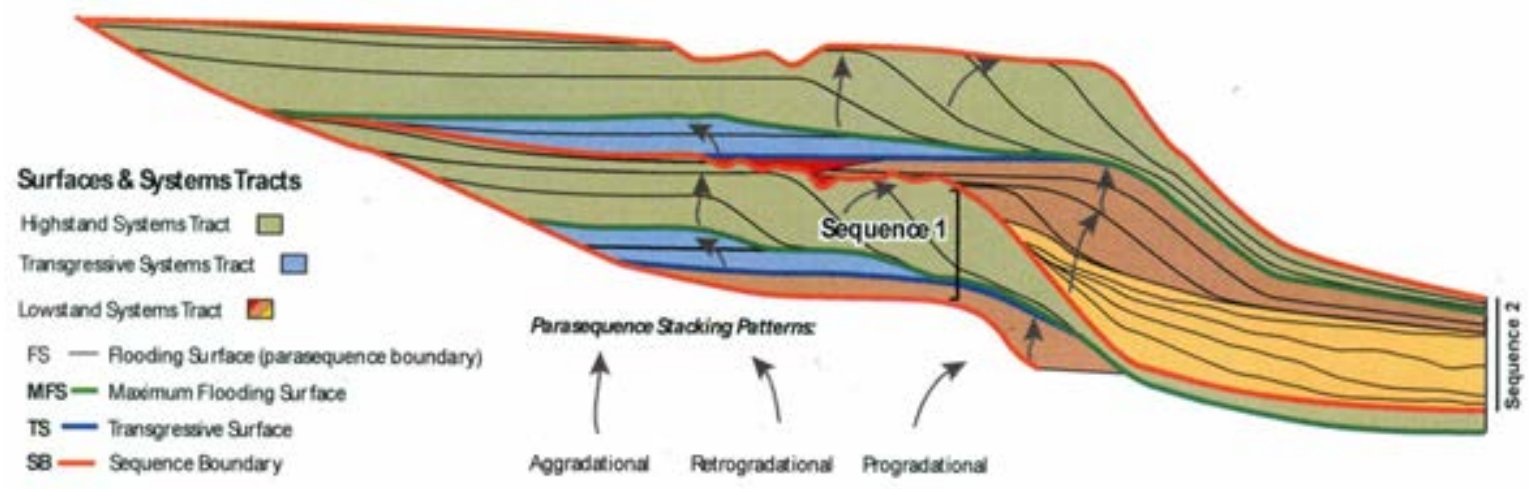

Figure 2.6. Depositional sequence of a basin margin illustrating different surfaces and systems tracts with parasequence stacking patterns (modified from Bohacs and Schroeder, 2010).

Systems tracts are made up of parasequence sets, which are defined by flooding surfaces from fluctuations in sea-level or correlative surfaces formed by erosion, non-deposition, or very slow sedimentation (Bohacs and Lazar, 2010). Parasequence stacking patterns, such as retrogradational, aggradational, and progradational, are used to define systems tracts by looking at gamma ray (GR) trends (Kohl et al., 2014). Systems tracts are defined by their position within 
the $3^{\text {rd }}$ order depositional sequence and include highstand, lowstand, and transgressive system tracts. The highstand system tracts (HST) represent a vertical to seaward movement of the shoreline. The HST is deposited in an aggradational to progradational stacking pattern after the maximum flooding surface (MFS), as relative sea level-rise started to slow down and during the initial part of relative sea-level fall. The lowstand system tracts (LST) represent a regression of land seaward to vertical in direction that is deposited in a progradational to aggradational stacking pattern. The LST is deposited during relative fall and lowstand of sea-level into the beginning stages of sea-level rise. Above the LST is the transgressive system tracts (TST), which is separated by the maximum regressive surface (MRS), the TST is deposited during a period of rapid sea-level rise (stepping landward), producing a retrogradational stacking pattern (Bohacs and Lazar, 2010). Another system tract, the falling stage system tracts (FSST), used by Kohl et al (2014) in his analysis of the Marcellus Formation, to describe a strictly progradational stacking pattern due to a forced regression from a period of sea-level fall.

The Onondaga Formation was subdivided into four members (in ascending order): Edgecliff, Nedrow, Moorehouse, and Seneca (Brett et al., 2011). Kohl et al. (2014) believed the four members correspond to four parasequences (PS-01, PS-02, PS-03, PS-04) (Fig. 2.7). The Edgecliff Member was equivalent to the first parasequence, PS-01, while the second and third, PS-02 and PS-03, parasequences were equivalent to the Nedrow and Moorehouse, respectively. It was stated that parasequences PS-01 to PS-03 were deposited during a period of base-level rise and exhibited a progradational to aggradational stacking pattern that is associated with a LST. Carbonate production was sustained despite the increase in accommodation rate, which allowed a thick carbonate bank to form in northwest Pennsylvania. In central Pennsylvania, clean 
limestones graded into more argillaceous limestone and siltstone in the deeper part of the basin (Kohl et al., 2014).

Parasequence PS-04 is believed to correspond to the Seneca Member and bridges the contact between the Onondaga Formation and the lower Marcellus (Ver Straeten, 2004, Kohl et al., 2014). In central Pennsylvania, the packstones and wackestones of parasequence PS-04 grade into the organic-rich mudstone of the lower Marcellus. This interval also contains the Tioga Ash beds, which allow for chronostratigraphic correlation. Kohl et al. (2014) interpreted this parasequences as a TST, with the MFS located where the GR value is at its highest (Fig. 2.7) (Kohl et al., 2014). The Onondaga-lower Marcellus contact, as seen in Figure 2.5, and is located at the first sign of the black shale interval.

The Marcellus Formation is composed of two coarsening upwards transgressiveregressive sequences, named MSS1 and MSS2 by Lash and Engelder (2011), which correspond, in ascending order, to the lower and upper Marcellus. The Purcell Member reflects a momentary lowstand or regression between the upper and lower Marcellus (Lash and Engelder, 2011). Lash and Engelder (2011) developed sequence-stratigraphic type log for the Marcellus Formation from a compilation of wells across the basin (Fig. 2.8). This type log also included the upper part of the underlying Onondaga Formation and the lower part of the Skaneateles or Mahantango Formation, similar to the cored portion of the study interval. The type log provided a good illustration of the transgressive-regressive system tracts and sequence boundaries in relation to GR and density log.

The lower Marcellus (MSS1) included the TST at the base in which Kohl et al. (2014) named Parasequence PS-04, as mentioned above. The MRS located close to or at the top of the Onondaga Formation marked a rise in base level and the start of the TST. The MFS marked the 
start of a coarsening upward regressive stacking pattern indicative LST or HST as base-level started to fall (Lash and Engelder, 2011). Kohl et al. (2014) divided the lower Marcellus and Purcell Member into six parasequences (PS-US1 to PS-US6) and stated that there are two lithologic units: the basal unit characterized by black mudstone and the upper two thirds of the lower Marcellus characterized by a silt-rich mudstone. Kohl et al. (2014) identified the parasequence PS-US1 as part of a HST, where deposition took place during the slowing down of base-level rise and the initial part of the relative base-level fall (Bohacs and Lazar, 2010). Above PS-US1 is Parasequence PS-US2, which is interpreted to be a FSST, a result of a forced regression due to a period of base-level fall. Parasequences PS-US3 to PS-US6 was interpreted to be in the late FSST due to the progradation of Mahantango delta complex (Kohl et al., 2014).

The Purcell Member was identified as a LST at the top of MSS1 and before the upper Marcellus transgressive-regressive depositional sequence (MSS2). The fall in base-level exposed carbonate platform areas bordering the basin to the west increasing carbonate input that derived the Purcell Member (Werne et al., 2002, Lash and Engelder, 2011, Kohl et al., 2014). MRS lies within the Purcell Member, which signified the start of the TST and initial base-level rise that resulted in the base of the upper Marcellus (Lash and Engelder, 2011).

Although the upper Marcellus (MSS2) was not divided into parasequences by Kohl et al. (2014), the sequence stratigraphy of this interval was studied extensively by others, such as Ver Straeten, Brett and Sageman (2011) as well as Lash and Engelder (2011). The contact between the Purcell Member and the upper Marcellus was found to be irregular and incised due to a possible unconformity during the Purcell Member lowstand (Sageman et al., 2003). The rise in base-level that initiated the TST in the basal part of the upper Marcellus created a condensed section. The upper Marcellus condensed section grew increasingly more organic-rich as it 
approached the MFS. A thin fossiliferous limestone, possibly the Halihan Hill bed, located low in the upper Marcellus represented the end of the TST (Ver Straeten, Brett, and Sageman, 2011). At this point, a more progradational or aggradational stacking pattern began due to the slowing of base-level rise and an increase in sediment supply (Lash and Engelder, 2011). Lash and Engelder (2011) identified the top of the upper Marcellus as regressive systems tract (RST), while Ver Straeten, Brett, and Sageman (2011) were more specific, and determined it a HST. The Mahantango Formation also displayed a transgressive-regressive depositional sequence, identified as SKS in Figure 2.8 (Lash and Engelder, 2011). The Stafford member is the basal unit of the Mahantango Formation and marks the end of the upper Marcellus. The Stafford Member was most likely a lowstand carbonate unit with its upper boundary at the beginning of a TST. It is interpreted that the TST in the Mahantango Formation transitioned into an early HST and then into a late HST of the Skaneateles Member, where facies patterns were aggradational at first, but became shallower later (Ver Straeten, Brett, and Sageman, 2011). 


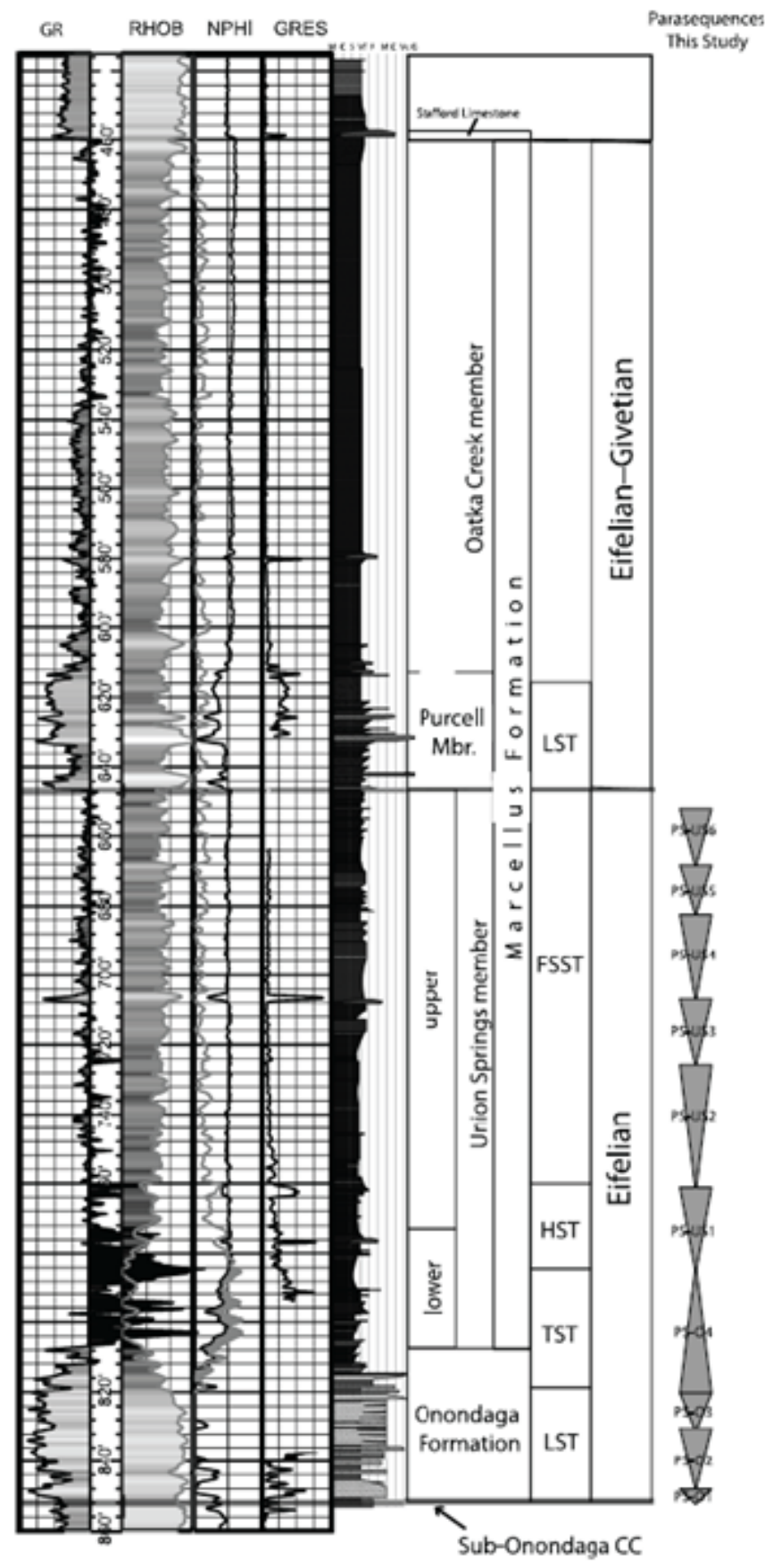

Figure 2.7. Sequence-stratigraphic interpretations from Kohl et al. (2014) for the lower Marcellus Formation. Parasequence sets and systems tracts are identified and abbreviations are defined in the text. Also shown are wireline and graphic logs that guided these interpretations, as well as stratigraphic nomenclature and sequence-stratigraphic interpretations (from Kohl et al., 2014). $\mathrm{GR}=$ gamma ray $\log , \mathrm{RHOB}=$ bulk density $\log , \mathrm{NPHI}=$ neutron porosity $\log , \mathrm{DPOR}=$ density porosity log, GRES = guard resistivity. 


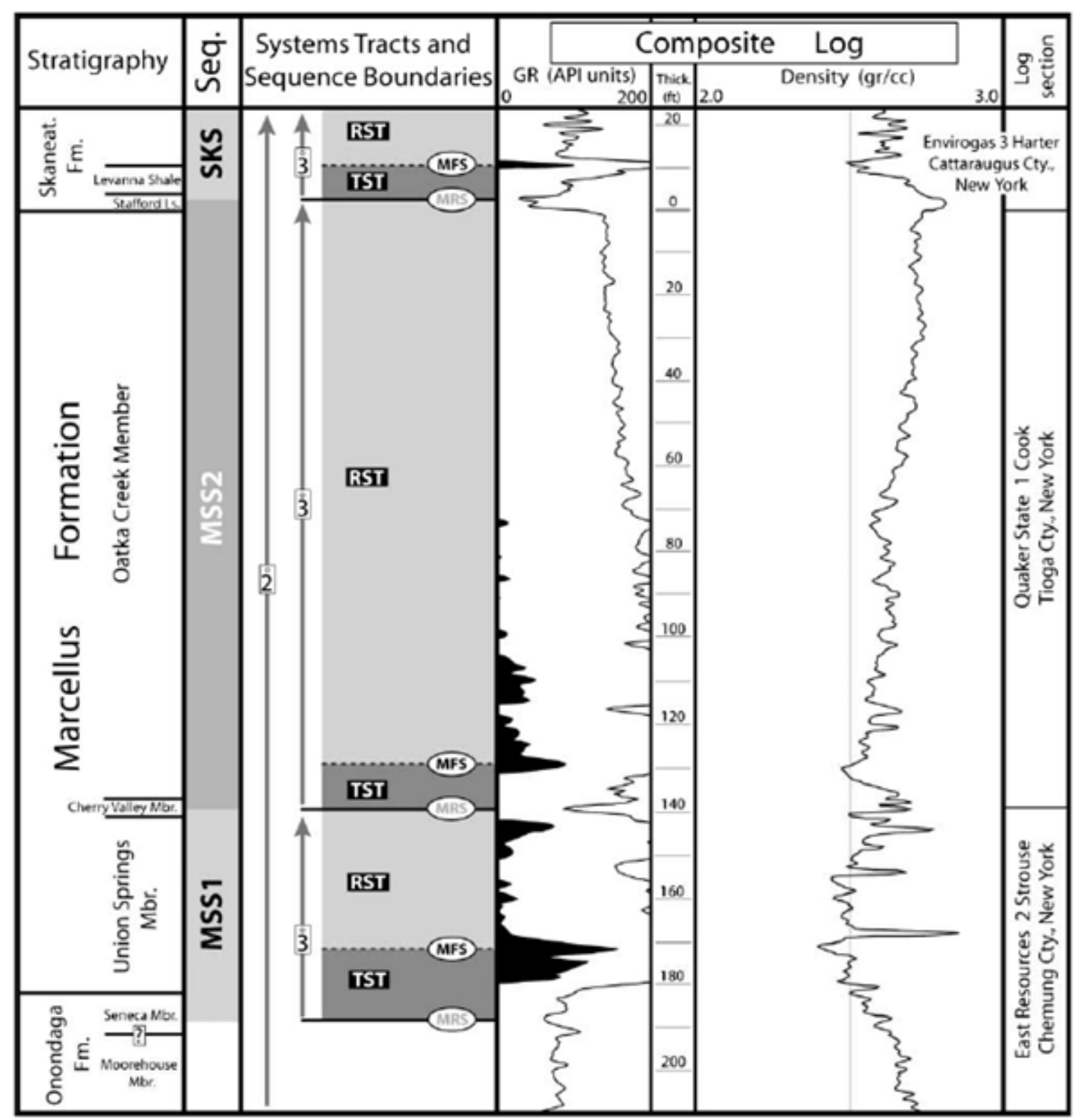

Figure 2.8. Sequence stratigraphic type log illustrating the third order depositional systems tracts for the Marcellus Formation from a compilation of wells across the across the basin. The top of the Onondaga Formation and bottom of the Mahantango Formation (SKS) are also recognized in this type log (from Lash and Engelder, 2011).

\subsection{Mudstone Diversity}

Mudstone units are the most abundant sedimentary rocks as well as being important

lithofacies for exploration, acting as seals, sources, and reservoirs (Aplin and Macquaker, 2011). 
Thus, research on mudstone lithofacies has exploded in recent years, as industry and academia alike are pursuing a better knowledge and understanding of their diversity. Understanding the fundamental differences within mudstone units is imperative for the interpretation of lithofacies and sequence stratigraphy, and helps evaluate the properties that make organic-rich black shale facies ideal for exploration. A general knowledge regarding the heterogeneous nature of black shale is the first step to interpreting factors that affect reservoir quality. These variations are the product of changes in lithology, depositional environment, and diagenesis, which affect mineralogy, organic matter, and the pore structure of the mudstone.

Mudstone diversity, in a marine environment, is the result of weathering, production within the water column, and the chemical and physical changes that take place during diagenesis. Variability within these components affects the overall lithology, which is often determined by the mineralogy, including the silt/clay ratio, organic components, and diagenetic reactions. The general mineralogy of mudstones consist of quartz, feldspar, carbonate, sulfides, amorphous material, organic matter, and mixed variety of clay minerals (Alpin and Macquaker, 2011). Organic material is the result of primary production in the photic zone along with some terrestrial organic components. The mineralogical and biogenetic characteristics of mudstone deposition from the overlying water column precondition the diagenetic reactions during burial (Alpin and Macquaker, 2011).

Research by Andrew C. Alpin and Joe H.S. Macquaker (2011) sought to explain the origin and implications of mudstone diversity. They determined that the clastic sediment is delivered to the ocean by rivers with minimal input from volcanic activity and eolian environments. These clastic particles are dispersed as suspended sediment, waves, gravity induced flows, and by storm and tidal currents that eventually settle in a slope or basin setting 
(Alpin and Macquaker, 2011). These methods of delivery stack mudstones into packages that can be defined within a sequence stratigraphic framework. Biological processes also deliver particles to the slope and basin setting through organic grain aggregates or "marine snow". Marine snow is formed from the collision of particles and from organisms ingesting the sediments that are then excreted as pellets (Alpin and Macquaker, 2011, Shanks, 2002). It has been suggested, more recently, that these aggregates are the leading factor in enhancing organic matter preservation and creating localized anoxic environments (Boyce, 2010). Learning the origin behind mudstone diversity helped pave the way to interpreting more quantitative aspects of shale-gas reservoirs.

Other research by Jesus Ochoa, Jeannette Wolak, and Michael H. Gardner (2013) distinguished between hemiplegic and pelagic mudrock to characterize deep water heterogeneity. They used scanning electron microscopy (SEM) and x-ray diffraction (XRD) for a Woodford Shale core to identify clay fabric and mineralogy of the mudrock. Hemiplegic mudrocks transported detrital (allochthonous) components into the basin by physical and chemical weathering in soils as well as some terrestrial organic elements. (Ochoa, Wolak, and Gardner, 2013, Macquaker et al., 2013; Ochoa et al., 2013). The main products of physical and chemical weathering are clay minerals and silt, largely composed of quartz, but minor amounts of feldspar and lithic minerals are also present (Macquaker et al., 2013). Hemipelagic mudrocks were deposited in the deep-water by turbidites or storm and wave enhanced gravity flows. Therefore, hemipelagic mudrocks exhibit different textures, fabrics, and reservoir properties than pelagic mudrocks, which settle vertically due to gravity. Ochoa et al. (2013) concluded that hemipelagic mudrocks display a more disorganized clay fabric and higher portion of denser particles, while pelagic mudrocks exhibit the opposite, organized clay fabrics and a lower portion of denser 
particles. Pelagic mudrocks are classified as having biogenic or production-derived (autochthonous) components which form in the overlying water column and settle to the bottom (Ochoa et al., 2013; Macquaker et al., 2013). The production-derived components consist of mineralized tests and skeletal products of organisms, and organic carbon from the photic zone (Macquaker et al., 2013).

The process of deposition, compaction, and diagenesis is very slow, which explains why heterogeneity changes significantly over a meter of shale lithofacies. The geologic and biotic conditions at the time of deposition determine the mudstone composition (Passey et al., 2010). Muds are deposited as a mixture of minerals, organic matter, and biogenic components that are compacted and eventually lithified. During early diagenesis, organic matter fuels biological reactions and oxidation takes place to produce early diagenetic minerals such as calcite, dolomite, siderite, and pyrite (Aplin and Macquaker, 2011). As depth increases, sediments leave the initial oxidation and sulfate reduction state to pass through underlying diagenetic zones. Figure 2.9 is an early illustration of the diagenetic zones, from a paper by Harry A. Tourtelot (1979) on black shales, which shows the relative depth and temperature in relation to the products of the different zones. Between 70 to $100^{\circ} \mathrm{C}$, smectite is converted to illite in a chemical reaction, where potassium, generally associated with potassium feldspar, is required to facilitate illitization. One of the byproduct of illitization besides illite is quartz since smectite is typically more siliceous than illite, the reaction generates excess diagenetic silica (Alpin and Macquaker, 2011). Therefore, illitization facilitates brittleness and is an indicator of the degree of diagenesis in a mudstone. 


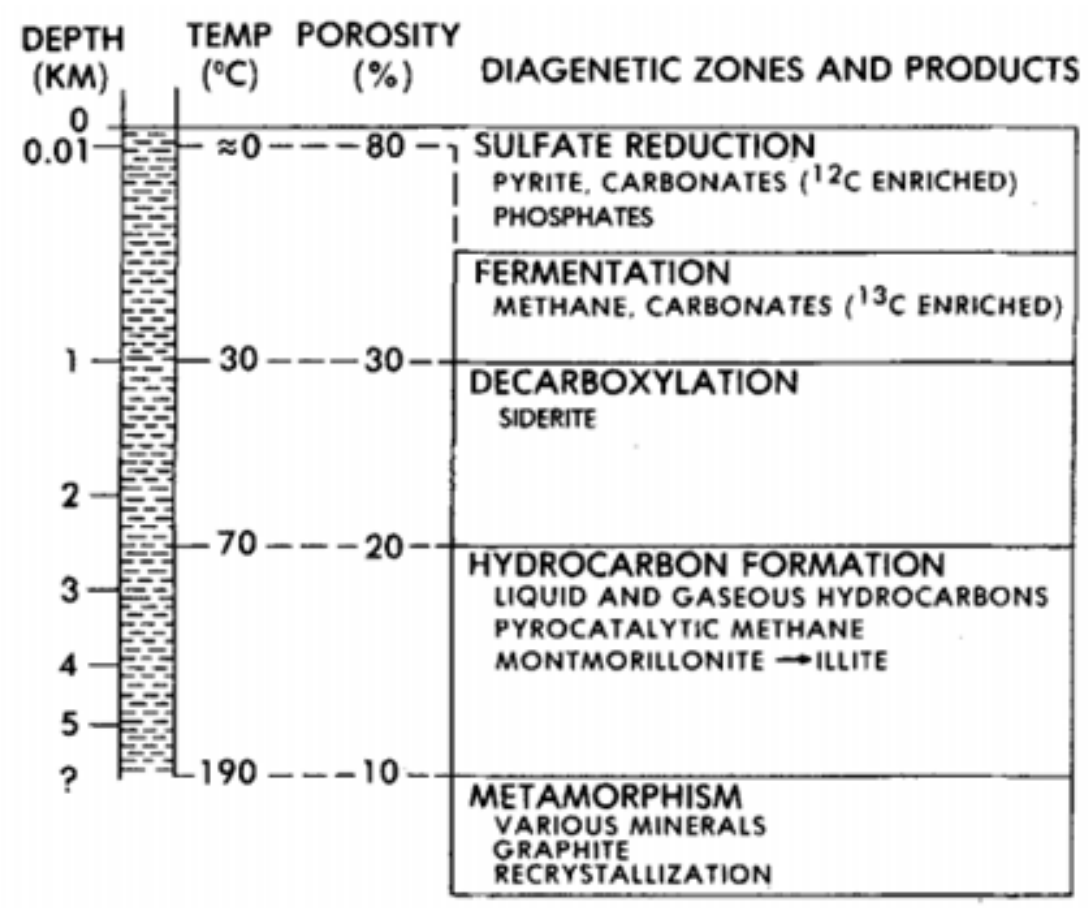

Figure 2.9. Models of diagenetic zones and products with approximated boundaries that are applicable to relative depth, temperature, and porosity (Tourtelot, 1979).

Depth and porosity are inversely related during diagenesis (Fig. 2.9), as depth increases, porosity will decrease due to compaction and lithification of the muds. Pores and pore networks found in these muds are inherently tied to reservoir properties relating to storage, hydrocarbon prediction, and sealing capacity. Muds are known to have nanometer to micro-size pores, much smaller than carbonate or siliceous sediments. The mineralogy, fabric, texture, and organic matter act as important controls on mudrock pore types and the development of pore networks. Mineralogical composition, in particular, is a major factor in the development and preservation of mudrock pore space, which can be attributed to the mechanical and chemical stability of particular minerals, as illustrated in Figure 2.10, with different minerals at each apex, reflecting their relationship to stability. Clay is a ductile mineral that is mechanically and chemically 
unstable, which is more susceptible to deformation leading to potential pore loss during compaction (Loucks et al., 2012).

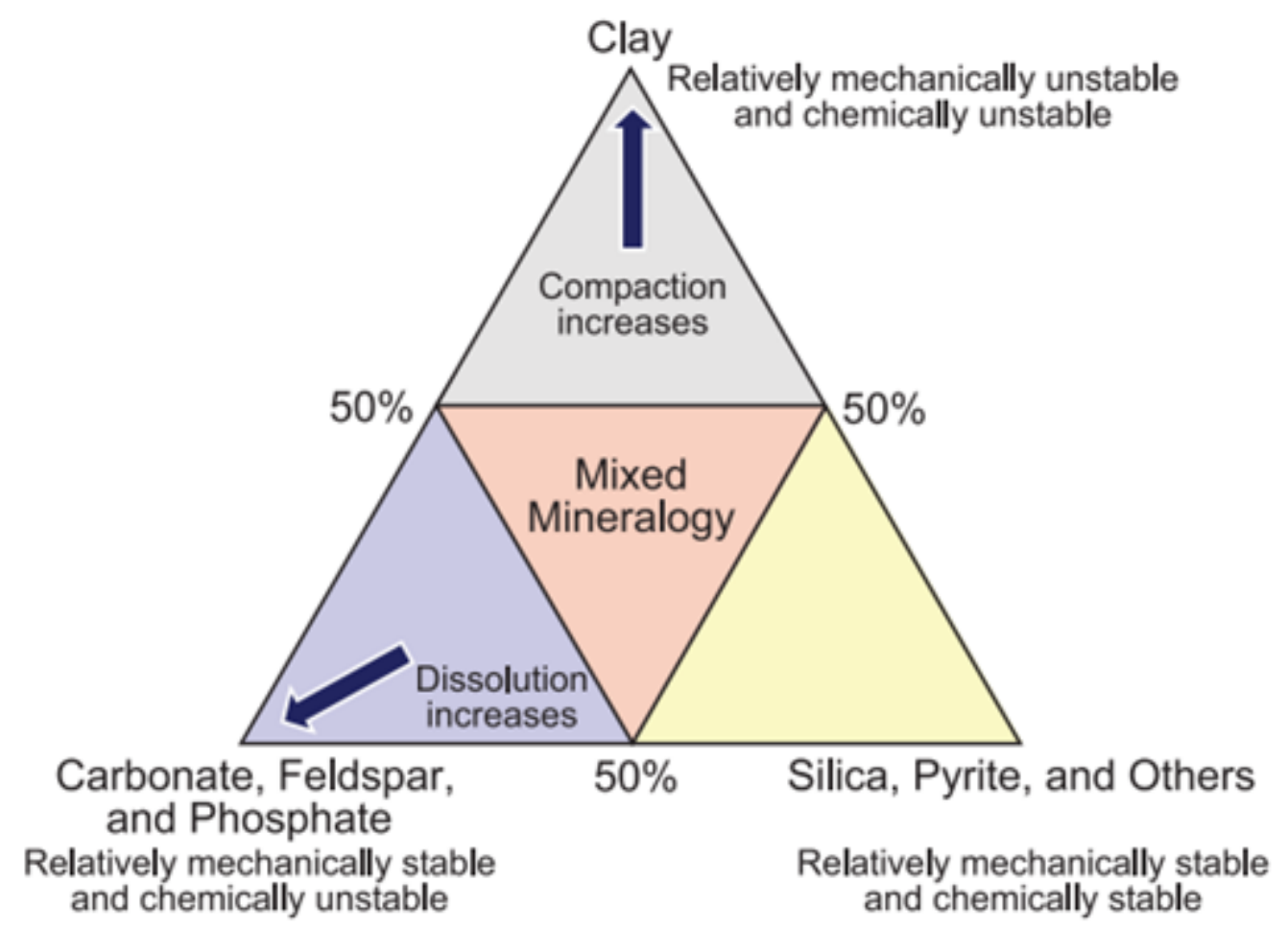

Figure 2.10. Tertiary diagram of the mineralogical composition of mudrocks and how mechanical and chemical stability relate to pore space. Clay is relatively unstable mechanically and chemically making clay minerals more susceptible to deformation from compaction. Carbonate, phosphate and feldspar minerals are mechanically stable but chemically susceptible to dissolution, while quartz and pyrite are the most stable and less likely to sustain major pore loss (Loucks et al., 2012). 


\section{Previous Work}

The Marcellus Formation as an unconventional reservoir has become a major target for shale-gas production in the United States. Increased interest in the Marcellus Formation has led to research, from both academia and industry that allows for a better understanding of the reservoir characteristics that affect production. Reservoir characteristics, such as porosity and permeability, total organic carbon, geomechanics, sedimentary and structural features, fluid saturations, as well as rock composition, for the most part, have been studied on a basinal scale (Bratovich, , 2012). However, more localized studies, specifically in Clearfield County, Pennsylvania, the area of interest, have not been researched with as much scrutiny in comparison to the higher production areas of southwestern and northeastern Pennsylvania.

Research in Clearfield County, conducted by Cole Bowers (2014) and Emily Roberts (2013), on the structural features and geomechanics of this area confirmed its structural complexity. Bowers (2014) concluded, through 3D seismic analysis, that structure was complex due to kink band folding, large cross-strike and strike-slip faults, as well as proximity to the Chestnut Ridge Anticline (Fig. 3.1). It was determined that displacement was smaller and no large scale folding existed in the area, unlike prior research associated with the Chestnut Ridge Anticline (Scanlin and Engelder, 2005). Bowers (2014) interpreted that the structures were related to the Allegheny orogeny and most likely salt migration from the Salina Group, and deformation was simultaneous instead of syndepostional. Roberts (2013) research on Clearfield County confirmed that fracture and fault, dip and azimuth are consistent with previous interpretations. Roberts (2013) also interpreted that seismic faults may be surrounded by fracture swarms and fault damage zones that could potentially be harmful to production (Roberts, 2013).

Other research on a basinal scale (Zagorski et al, 2012, Boyce, 2010, Yanni, 2010) showed comparable depth, pressure gradient, thickness, total organic carbon, and thermal 
maturity to Clearfield County. Porosity, permeability, and fluid saturations have not been mapped at a basin-wide scale making comparison difficult (Bowers, 2014). Rock composition, mineralogy, and lithology were determined through varying methodologies. Outcrop and core data, along with digital logs, helped to generate lithofacies in Wang (2012) and Walker-Milani (2011). Lash and Engelder (2011), Boyce (2010), and Yanni (2010) studied thickness trends associated with the study interval that revealed important information regarding stratigraphy and depositional patterns.

Wang (2012) identified and mapped seven lithofacies for the Marcellus Formation using core x-ray diffraction (XRD) and pulsed neutron spectroscopy (PNS) logs. The lithofacies map revealed that more clay minerals are present in Clearfield County when compared to southwestern Pennsylvania. In Clearfield County, the upper Marcellus is a gray mudstone, while the lower Marcellus is more of an organic-rich to gray mudstone (Wang, 2012). A lithostratigraphic outcrop study based on observations and XRD data by Walker-Milani (2011) identified six distinct lithofacies: gray calcareous shale, limestone, black calcareous shale, black non-calcareous shale, grey non-calcareous shale, and K-bentonite. Both techniques were successful at predicting similar lithofacies for the Marcellus Formation.

Lash and Engelder (2011) suggested that reactivated basement structures, such as the Rome Trough, influenced local thickness variations in lower and upper Marcellus of Pennsylvania (Fig. 3.2). It is believed that localized areas of uplift and erosion were located on topographic highs, especially in the northwest Pennsylvania and southwest New York, since the lower Marcellus was absent from gamma-ray (GR) logs. It was interpreted from cross-sections based on GR response, that organic matter rained out of the water column and concentrated on these topographic highs as condensed sections, while organic lean sediments ponded in adjacent 
bathymetric lows (Lash and Engelder, 2011). Furthermore, Lash and Engelder (2011) pointed out that previous work presented evidence that anticlines, such as the Chestnut Ridge Anticline, were active during deposition of the Marcellus Formation, and that the Marcellus demonstrated a thickening in the hinges of these anticlines.

Research by Boyce (2010) interpreted regional depositional patterns to be a product of basement or small salt structures that affected local topography, and facilitated favorable conditions for organic matter production. Boyce (2010) believed small localized microenvironments influenced by underlying structure helped explain rapid changes in thickness and organic-richness in the Marcellus Formation. Yanni (2010) and Boyce (2010) created isopach maps of the Onondaga and Marcellus (Fig 3.3). The Onondaga map revealed a thick, topographically high, shelf-break environment in the east, while adjacent structural lows revealed localized areas of thinner Onondaga Limestone. The topographic high associated with the Onondaga influenced the deposition of the Marcellus Formation. Unlike Lash and Engelder (2011), who suggested organic matter was concentrated on topographic highs, Boyce (2010) concluded that the most organic-rich shale was deposited in bathymetric lows.

Parrish's (2013) work on zircon geochronology for the dating of volcanic ash layers suggested the lower Marcellus was deposited diachronously. The age distribution was inconsistent with the Acadian foreland basin fill model developed by Ettensohn (2004). Instead of the oldest ashes being deposited close to the eastern margin, the oldest ashes were found in the western distal area of the Appalachian basin. Figure 3.4 illustrates the average age of each ash nearest to the base of the lower Marcellus, with the Coldstream well falling on the $392 \mathrm{Ma}$ contour line. This suggested that the basin bathymetry and associated depocenters, which were created by preexisting basement structures acted as a dominant control for deposition or 
preservation of the ash. The subtle west to east retrogradational trend could indicate that the earliest lower Marcellus is not a part of the clastic wedge but was deposited by in-situ sedimentation and windblown sediments or that anoxia progressed west to east (Parrish, 2013).

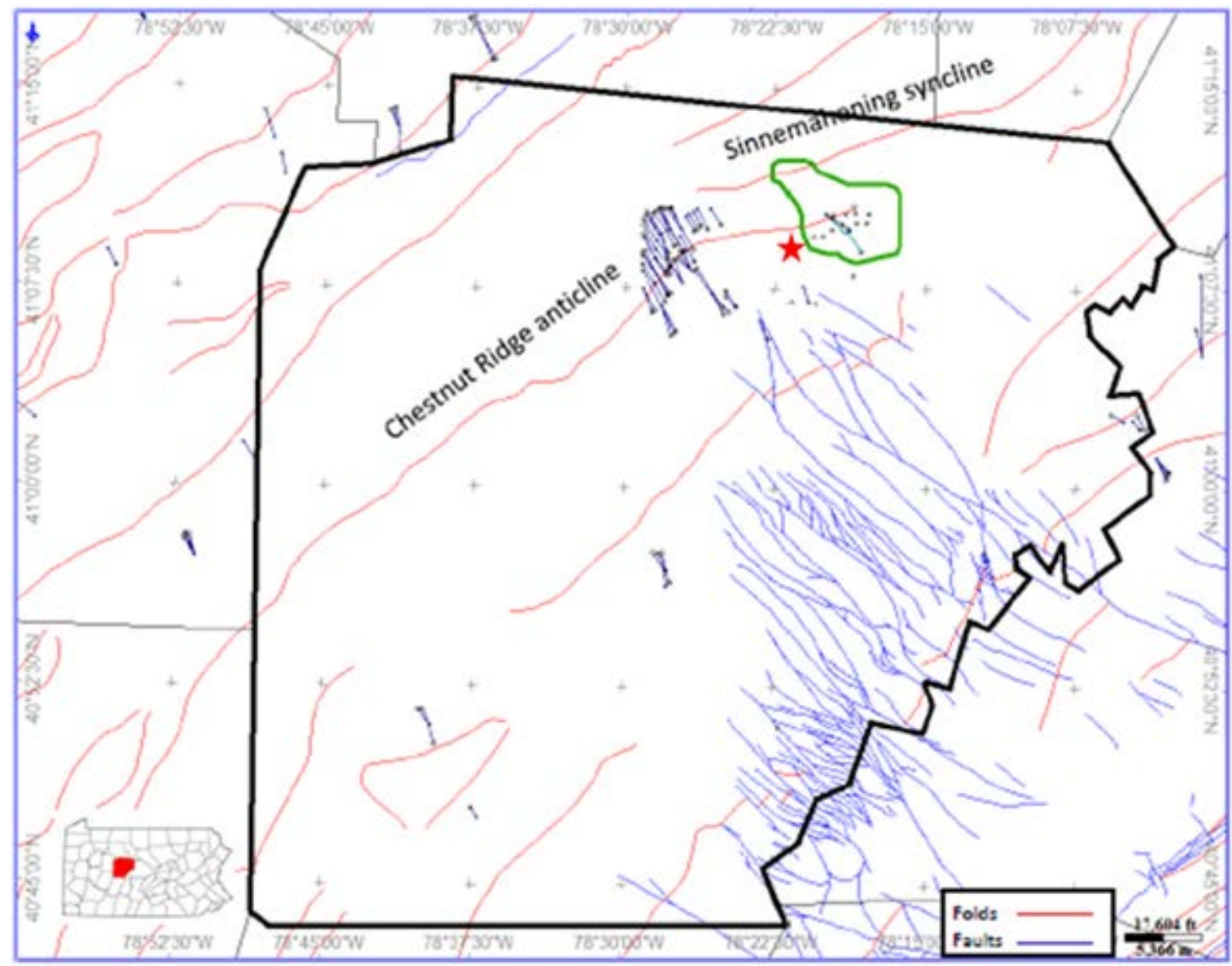

Figure 3.1. Surface folds and faults mapped in Clearfield County highlights the structual complexity of the area. The green outline illustrates the location of the 3D seismic data set used by Bowers (2014) and Roberts (2013) in relation to the study well (red star). The Chestnut Ridge Anticline terminates within the data set, while stike-slip faults terminate two miles south of data set (Bowers, 2014). 


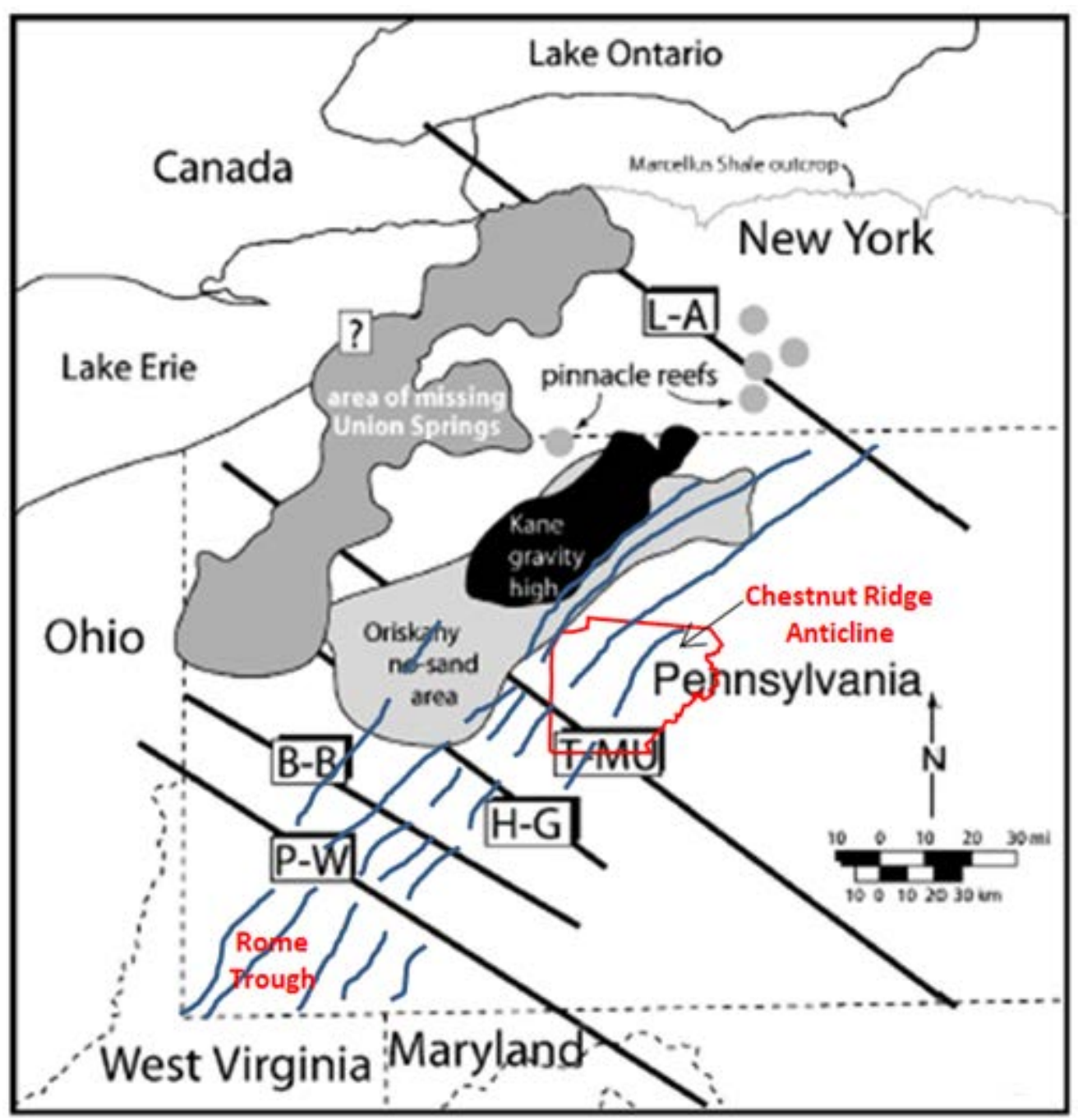

Figure 3.2. Map of reactivated basement structures and blind cross-stuctural discontinuities in relation to Clearfield County. The map illustrates the area of missing Union Springs/lower Marcellus and Oriskany no-sand area that were interpreted to be topographic highs, and erosion resulting from uplift associated with block displacement. It is believed that anticlines, such as the Chestnut Ridge Anticline, were active during deposition of the Marcellus Formation, and the Marcellus demonstrated thickening in the hinges of these anticlines (Lash and Engelder, 2011). The cross-structural discontinuities: L-A = Lawerenceville-Attica; T-MU = Tyrone-Mount Union; $\mathrm{H}-\mathrm{G}=$ Home-Gallistzin, $\mathrm{B}-\mathrm{B}=$ Blairsville-Broadtop, $\mathrm{P}-\mathrm{W}=$ Pittsburgh-Washington (modified from Lash and Engelder, 2011). 

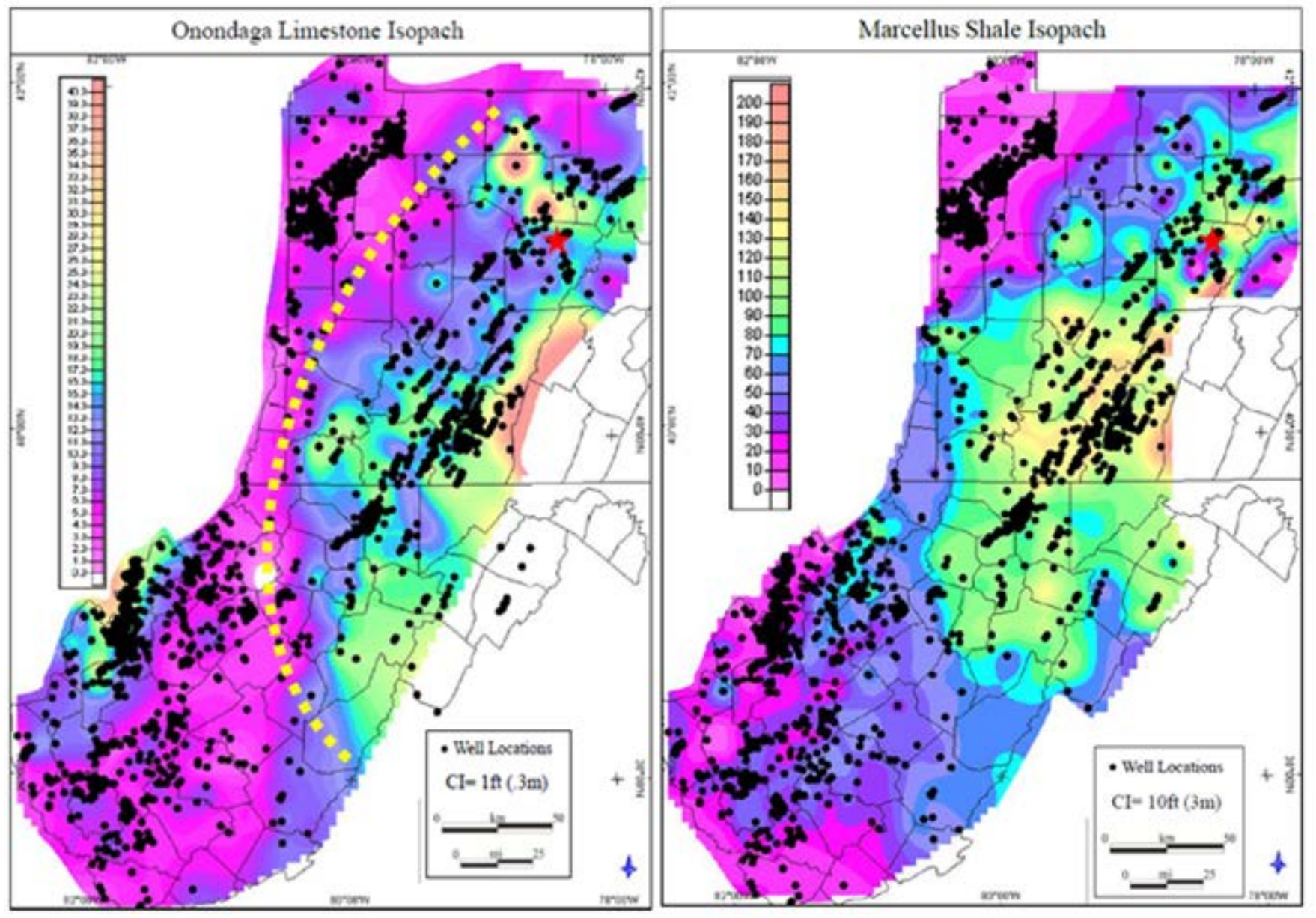

Figure 3.3. Onondaga and Marcellus isopach maps created by Boyce (2010) and Yanni (2010). The Onondaga Limestone ispach revealed a thick, topographic high to the east that was interpreted to be a shelf-break environment. The topography of the Onondaga influenced the depositon of the Marcellus Formation. It was interpreted that bathemetric lows were more favorable for organic production and preservation (Boyce, 2010, and Yanni, 2010). 


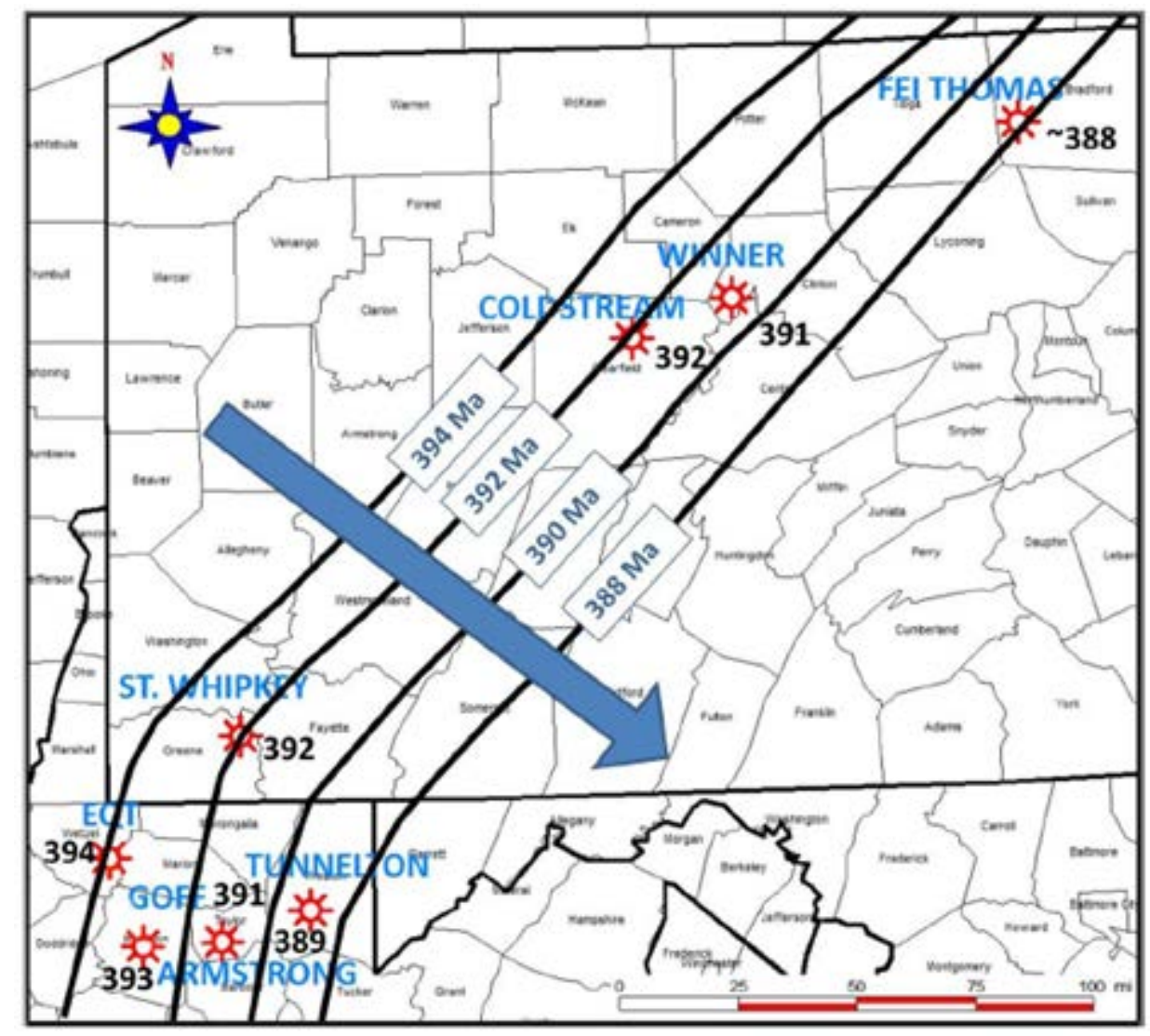

Figure 3.4. A contour map of the average ash ages for the basal unit of the lower Marcellus. The ash ages are oldest in the western distal part of the basin and become younger to the east. This contradicts the Acadian foreland basin fill model, which assumes that sediments become younger from east to west. Clearfield County, specifically ECA's Coldstream \#1MH well, falls on the 392 Ma contour line (Parrish, 2013).

\section{Data Set and Methodology}

The Cold Stream Affiliates \#1MH well located in Clearfield County, Pennsylvania is a pilot well drilled by Energy Corporation of America (ECA). Data for Cold Stream Affiliates \#1MH is shared in part with a joint industry project, the Marcellus Shale Consortium, and West Virginia University (WVU). The physical core was sent to Core Laboratories for petrographic and geochemical analysis prior to the donation to WVU. The data inventory applicable to this study is listed in Table 4.1 and 4.2. This study presents a continuous, 173.65 feet $(52.9 \mathrm{~m})$ 
vertical core, ranging in depth from 7,002.00 to 7,175.65 feet $(2134.2-2187.1 \mathrm{~m})$ in vertical thickness. The slabbed core specimen stratigraphically encompassed the Mahantango, Marcellus, Onondaga, and Huntersville Chert formations. The 4 inch diameter core was cut vertically and perpendicular to the bedding plane and sectioned into boxes with lengths ranging from 0.65 to 3.00 feet $(0.2$ to $0.9 \mathrm{~m})$. Core/log correction was approximated as $13.50(4 \mathrm{~m})$ feet to be subtracted from core depth. The correction was calculated based on the correlation of the well gamma ray curve to the spectral core gamma ray curve. Table 4.3 identifies the stratigraphy for the cored well, in addition to noting the core/log depth and thickness of each interval.

Ingrain, a digital rock physics laboratory, located in Houston, Texas, analyzed the whole core using Ingrain's CoreHD ${ }^{\circledR}$ Whole Core High Definition CT Scanning and Logging service. The data inventory of Ingrain's deliverables is listed in Table 2 below. Ingrain provided West Virginia University with a color-coded lithofacies analysis of the entire core and a CT volume that included movie clips of each core section

Additional data was collected to supplement Core Labs TOC and XRD data. Forty-two samples, in addition to the seventeen samples from Core Lab, were taken and powdered for analysis in the Source Rock Analyzer conducted at the National Energy Technology Laboratory (NETL) and in the PANalytical X'Pert PRO XRD instrument at WVU's Shared Research Facility. 


\begin{tabular}{|l|}
\hline \multicolumn{1}{|c|}{$\begin{array}{c}\text { Cold Stream Affiliates \#1MH } \\
\text { Core Laboratories } \\
\text { Data Inventory }\end{array}$} \\
\hline \hline X-ray diffraction (XRD) - Bulk \\
\hline X-ray diffraction (XRD) - Clay \\
\hline Total Organic Carbon (TOC) and Pyrolysis \\
\hline Thin Section - Images \\
\hline Spectral Core Gamma Ray \\
\hline Electric Log - Curve Data \\
\hline Core images - Color, multi-row \\
\hline Fracture Descriptions \\
\hline Vitrinite Reflectance \\
\hline
\end{tabular}

\begin{tabular}{|l|}
\hline \multicolumn{1}{|c|}{$\begin{array}{c}\text { Cold Stream Affiliates \#1MH } \\
\text { Ingrain } \\
\text { Data Inventory }\end{array}$} \\
\hline \hline CT Volume \\
\hline CORE HD Logs \\
\hline CORE HD Cross Plots \\
\hline CORE HD Facies Classification \\
\hline Individual Core Section Reports \\
\hline Visualizations Report with Movies \\
\hline
\end{tabular}

Table 4.1. The table on the top left lists the core analysis data from Core Labs that will be evaluated for this study.

Table 4.2. The table on the bottom left lists the deliverables from the $\mathrm{X}$ ray $\mathrm{CT}$ scan performed by Ingrain in Houston, TX.

\begin{tabular}{|c|c|c|c|c|c|c|c|c|}
\hline \multicolumn{9}{|c|}{ STRATIGRAPHY FOR COLDSTREAM \#1MH CORE } \\
\hline \multirow{2}{*}{ GROUP } & \multirow{2}{*}{$\begin{array}{l}\text { FORMATION NAME } \\
\text { Or EQUIVALENT }\end{array}$} & \multirow{2}{*}{$\begin{array}{l}\text { MEMBER NAME } \\
\text { or EQUIVALENT }\end{array}$} & \multicolumn{2}{|c|}{ CORE DEPTH } & \multicolumn{2}{|c|}{ LOG DEPTH } & \multirow{2}{*}{\multicolumn{2}{|c|}{ THICKNESS }} \\
\hline & & & TO & FROM & TO & FROM & & \\
\hline \multirow{6}{*}{ Hamilton } & Mahantango & & $7002.00^{\prime}$ & $7055.10^{\prime}$ & $6988.50^{\prime}$ & $7041.60^{\prime}$ & 53. & $10^{\prime}$ \\
\hline & \multirow{3}{*}{ Marcellus } & Upper Marcellus & $7055.10^{\prime}$ & $7101.20^{\prime}$ & $7041.60^{\prime}$ & 7087.70' & $46.10^{\prime}$ & TOTAL \\
\hline & & Purcell Limestone & $7101.20^{\prime}$ & $7104.20^{\prime}$ & $7087.70^{\prime}$ & $7090.70^{\prime}$ & $3.00^{\prime}$ & \multirow{2}{*}{$105.55^{\prime}$} \\
\hline & & Lower Marcellus & $7104.20^{\prime}$ & $7160.65^{\prime}$ & $7090.70^{\prime}$ & $7147.15^{\prime}$ & $56.45^{\prime}$ & \\
\hline & Onondaga & & $7160.65^{\prime}$ & $7173.80^{\prime}$ & $7147.15^{\prime}$ & $7160.30^{\prime}$ & \multicolumn{2}{|c|}{$13.15^{\prime}$} \\
\hline & Huntersville Chert & & $7173.80^{\prime}$ & $7175.65^{\prime}$ & $7160.30^{\prime}$ & 7162.15 & \multicolumn{2}{|c|}{$1.85^{\prime}$} \\
\hline
\end{tabular}

Table 4.3. The stratigraphy for the Coldstream Affiliates Well, with core/log depth as well as the thickness for each stratigraphic interval. The core /log depth correction was approximated as 13.50 feet $(4 \mathrm{~m})$ subtracted from core depth, which was determined by correlating log gamma to spectral core gamma ray. 
The evaluation of the Clearfield County core produced a detailed, integrated model of sequence stratigraphy and an interpretation of depositional environment for the cored well. The model identified vertical variations in depth for the cored well by building a sequence stratigraphic framework, similar to the regional framework models used by Lash and Engelder (2011) and Kohl et al. (2014). The detailed sequence stratigraphic model and interpretation of depositional environment is based off the stacking patterns of lithofacies, which were identified through core analysis methods. Lithofacies were predicted by integrating data from core and petrographic descriptions, powdered X-ray diffraction (XRD), total organic carbon (TOC) pyrolysis, spectral gamma ray (GR), and digital rock physics (DRP).

For core description, a paper by Lazar et al. (2010) on classification and description guidelines for fine grain rocks in outcrops outlines a useful methodology for rock description, which was applied to this research. All the core observations were documented in a field notebook using a systematic format that illustrated scale, lithology legend, description, and other remarks. The core descriptions were compiled into a more descriptive graphic log by using Adobe Illustrator CC to draw the stratigraphic column. The graphic log includes formation name, core depth, lithology, grain size, location of XRD, TOC, and thin-section samples, sedimentary structures, fossils, bioturbation, concretion/bands, natural fractures, and notes. The detailed graphic log can be found in the appendix section of this paper, while a summarized core description and lithology log are in the results chapter.

Identifying sequences boundaries, and changes in lithology, specifically determining grain size variations, at the core scale can be difficult due to the condensed nature of fine-grained mudstones. A spectral core gamma-ray (GR) profile was utilized to detect and confirm suspected sequence boundaries and potential grain size variations during logging. Spectral GR 
also aided in interpreting stacking patterns of lithofacies as well as depositional/diagenetic properties. The spectral GR measures the amount of potassium (K), thorium (Th), and uranium (U), which reflect the natural radioactivity of the cored interval. A Th/K ratio curve was used to evaluate clay type (illite or smectite), while a $\mathrm{TH} / \mathrm{U}$ ratio determined redox potential (oxidizing or reducing), which reveals the degree of diagenesis and depositional pattern respectively.

The detailed core description was compared to $59 \mathrm{XRD}$ and TOC samples, and 17 thinsections. The integration of physical core, spectral GR, XRD, TOC, and thin-section data aided in the identification of core-scale lithofacies. Lithofacies classification consists of both qualitative and quantitative methods, which corresponds to minerals, type and origin (allogenic or authigenic), TOC percent, lamination, and biogenic components. Wang and Carr (2012) developed a workflow that classified lithofacies by a quantifying a relationship between XRD, TOC, and pulsed neutron spectroscopy (PNS) (Fig. 4.1). The classification workflow is for a regional lithofacies model and is too broad for this study. However, the workflow was useful at providing initial parameters for lithofacies prediction using mineralogy and TOC data. Other qualitative components, such as core and thin-section descriptions, were also incorporated for lithofacies classification. 


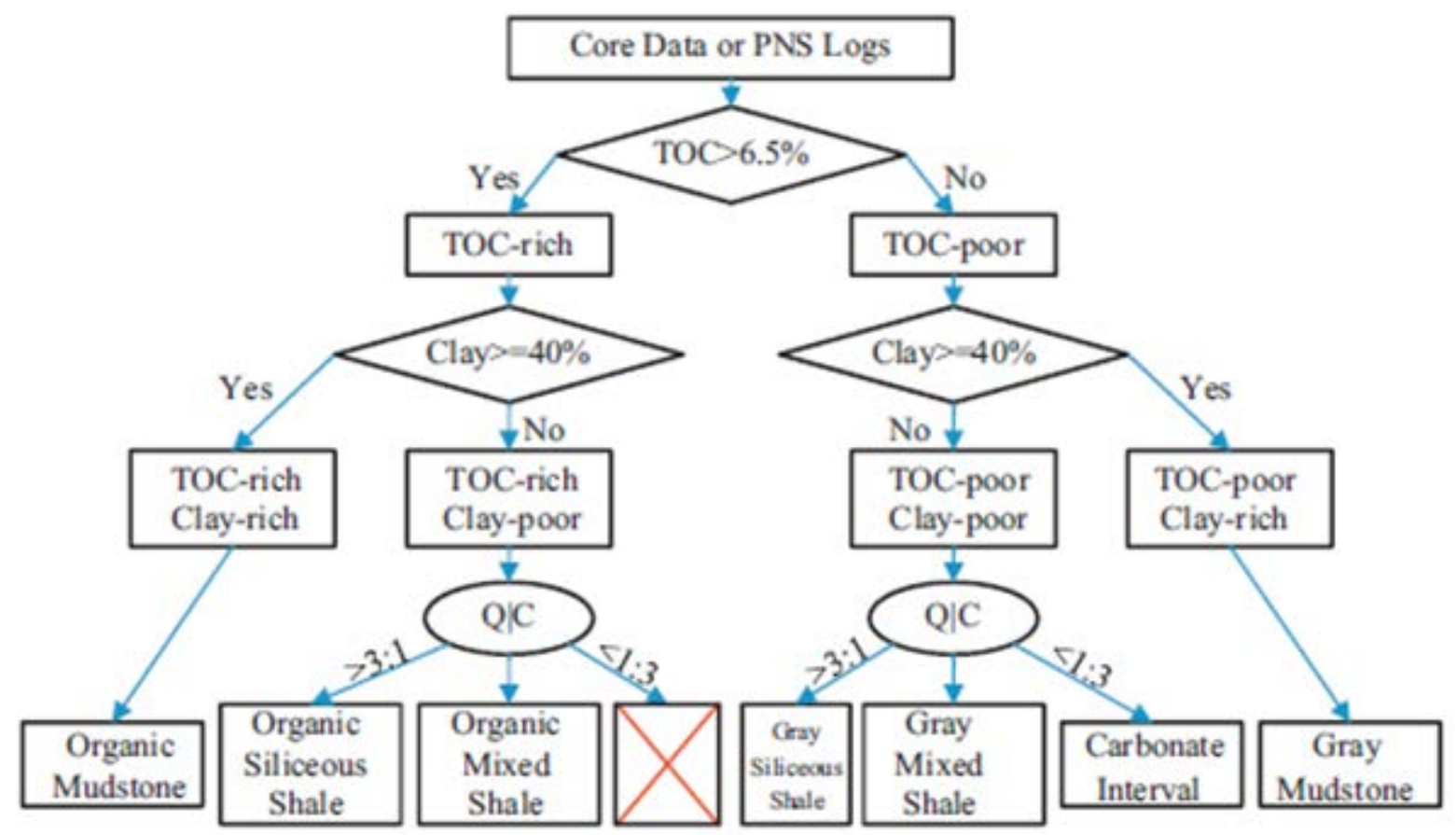

Figure 4.1. Workflow developed by Wang and Carr (2012) to classify shale lithofacies from core data in the Marcellus Formation.

Digital rock physics (DRP) was used in this research to supplement traditional core analysis methods. DRP is a new method of core analysis being used in the industry. This technique uses a much finer resolution compared to wireline logs, and is more thorough than thin-section analysis at specific intervals. The core was sent to Ingrain, a DRP laboratory, where they applied their color-coded lithofacies analysis. High-definition computed tomography (CT) scanning and logging techniques were used to confirm and supplement core-scale lithofacies. Comparing the spectral core GR log to Ingrain's CoreHD ${ }^{\circledR}$ lithofacies classification was an effective way to visualize the very small scale, vertical changes within the core interval that otherwise are difficult to interpret.

An initial log-ascii standard (LAS) file was provided for the Coldstream Affiliates well, and the file was used to generate computed logs, such as Umaa log, a product of bulk density and 
photoelectric absorption, TOC Schmoker, and a volumetric mineralogical model, were calculated using equation expression in Petra ${ }^{\circledR}$ and PowerLog ${ }^{\circledR}$.

The physical core data, specifically XRD and TOC, are calibrated to digital well log curves in Petra ${ }^{\circledR}$ and PowerLog ${ }^{\circledR}$ to understand petrophysical and mineralogical variation in the Marcellus Formation. Statmin module in PowerLog ${ }^{\circledR}$, a statistical program, is used to build a stochastic-mineralogical model. Using the correct parameters with XRD and TOC data as a control, an accurate well-scale mineralogical model and TOC Schmoker curve is generated to supplement the result of core analysis and digital rock physics. Unfortunately, it should be noted that the digital well logs do not extended the entire length of the cored interval, excluding the bottom of the lower Marcellus, where GR and TOC are the highest.

The ultimate goal is to integrate the results from core analysis, digital rock physics, and petrophysics together to produce a final product or visual model for the results of these methods. The final image should visually display system tracts and stratigraphic intervals, lithostratigraphy, spectral core GR, core-scale lithofacies log, DRP lithofacies, lithology, structural and sedimentary features, and $\mathrm{Th} / \mathrm{K}$ curve.

\section{Results}

Integration of visual descriptions and quantitative interpretations (Fig. 5.1) from this results section helped identify the following seven lithofacies: (1) organic-rich, siliceous shale; (2) organic-rich mudstone; (3) gray siliceous shale (4) gray mudstone; (5) calcareous shale; (6) limestone; and (7) calcareous concretion horizons. Core and thin-section descriptions, mineralogical modeling, organic matter evaluation, spectral core GR, and DRP results are discussed in the sections below. The results were integrated together for the prediction of 
lithofacies. Lithofacies were compared to a spectral core GR and digital rock physics (DRP) results to interpret stacking patterns that help to understand depositional environment and sequence stratigraphy.

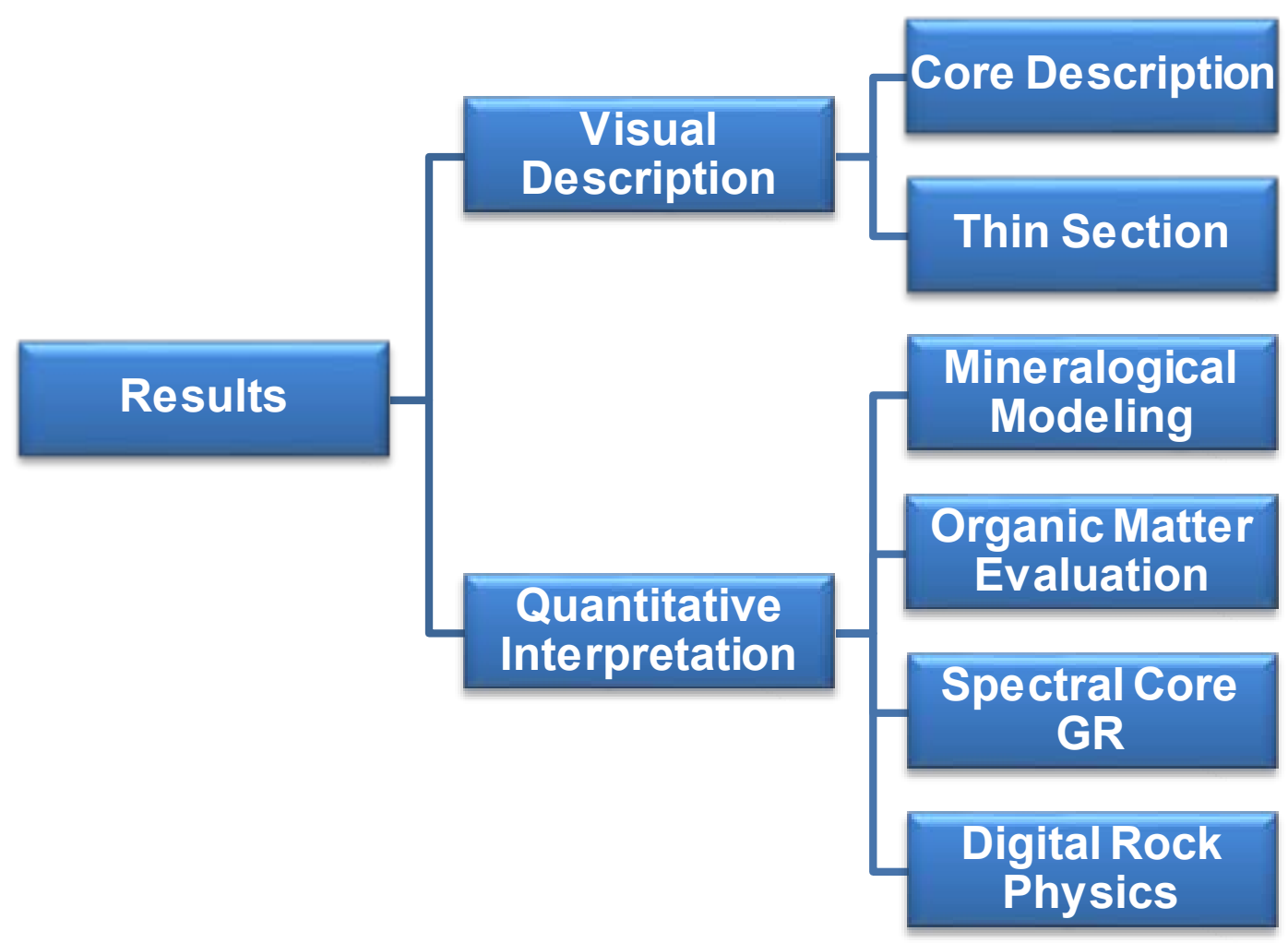

Figure 5.1. This schematic identifies the data being used in this study and acts as an outline for the results section.

\subsection{Visual Description}

The Coldstream Affiliates core is 173.65 feet $(53 \mathrm{~m})$ thick, ranging in depth from 7002.00 to 7175.65 feet (2134 to $2187 \mathrm{~m}$ ). The stratigraphy of the cored interval in relation to thickness and depth of formation is defined in Table 4.3. Sequence boundaries were interpreted while logging core and confirmed with spectral core GR. The core was described in great detail and is illustrated in a graphic log (Fig. 5.2 -5.3) that was drawn using Adobe Illustrator CC. 
Core descriptions were used in combination with thin-section descriptions for a more accurate and complete qualitative analysis of the core used during lithofacies classification.

\subsubsection{Core Description}

The methods that Lazar et al. (2010) established for the classification and description of fine grained rocks in outcrops were applied to this research. The core descriptions started by determining the "texture" or lithology of the core, for example whether it is a siltstone or coarse, medium, or fine grained mudstone. Coarse, medium, and fine corresponds to the amount and size of silt/quartz grains present in the mudstone. Applying a grain size modifier to a mudstone can be challenging due to its visually homogeneous appearance. In addition to a grain size modifier, a composition modifier was also applied to rock lithology, such as siliceous, calcareous, or argillaceous, based on the percent of silt, carbonate, and clay (Lazar et al., 2010).

The next step in the core description was the identification of sedimentary and structural features, which includes bedding/fabric, nodules/concretions, bioturbation, fossils, and fracture types and intensity. The bedding/fabric was described depending on the extent, shape and geometry of the beds or lamina. In this study well, laminations were hard to identify, especially in the Marcellus Formation. Laminations were identified in the Onondaga and Purcell limestone units as well as occasionally in thin-section, but overall the bedding appeared to be massive or weakly to moderately laminated. Nodules and concretions, along with mineralized fractures were the most evident and noticeable features in the core and were often in close proximity and sometimes cross cut each other. Bioturbation and fossils were the most abundant in the limestone and calcareous units. A detailed log of the core interval and subsequent features are submitted as an attachment to the appendix section of this paper (Core Description 1 [7126'7175.65'], Core Description 2 [7076'-7126'], and Core Description 3 [7002'-7076']). However, 
a summarized description of the physical core in relation to stratigraphy is illustrated in the Figures 5.2 through 5.5. The lithology logs in the following images were used in chapter 6 for comparison to core-scale lithofacies log.

The Marcellus Formation, in the study location, is predominately silt-rich shale, with varying amounts of calcite, organic, and clay content. The lower Marcellus (Fig. 5.2 and 5.3) is a grayish black to dark-gray, silty shale with high organic content, especially at the base of the interval where gamma-ray is highest, and low to moderate clay content. The carbonate content varies in this interval from non-calcareous to moderately calcareous. Calcareous shale is found primarily at the base of the interval, with a majority of the fractures being associated within the calcareous shale units. An interval of argillaceous limestone and fossiliferous limestone are found at the base of the lower Marcellus and are often interbedded with the calcareous shale units. Calcite concretions are present but not as abundant as in the upper Marcellus (Fig. 5.2 and 5.3). The lower Marcellus is pyritic, especially abundant at the base where the shale is organically rich. The upper Marcellus and the lower Marcellus are fairly similar, with the upper Marcellus having slightly lower organic-richness, more calcareous concretions, and slightly higher clay content. The upper Marcellus is grayish black to dark-gray, silty shale with higher organic content at the base of the interval. Clay content is moderate, while the carbonate content is low to moderate, with degree of calcareousness often being associated with calcareous concretions and/or fossil fragments. Fossils are in the form of small skeletal fragments, brachiopod shells, along with microfossils and microburrows. Fractures are generally located in close proximity to concretions, especially the large, pyritic, calcareous concretions (Fig. 5.6). Also, in the upper Marcellus there is a thin, 0.80 feet $(.24 \mathrm{~m})$ thick limestone/calcareous shale interval. 
The Purcell Limestone Member is relatively small, only 3 feet $(0.9 \mathrm{~m})$ in thickness, and consists of a dark-gray, bioturbated calcareous shale and an allochemical, argillaceous limestone (Fig. 5.7). The Purcell limestone contains moderate organic, high to moderate carbonate, and moderate clay content. Pyrite is in the form of bands and small nodules. Fractures are common, consisting of both closed natural, mineralized, and slickensided fractures.

The bottom 53.10 feet $(16.2 \mathrm{~m})$ of the Mahantango Formation was cored. It is a darkgray shale similar to the Marcellus, but it has lower organic content and higher clay content. Silt content is high to moderate and carbonate is low, with degree of calcareousness often being associated with calcareous concretions. Calcareous concretions have very little visible contrast with matrix, while pyrite nodules are present as well. Small fossil fragments and brachiopod shells are common. Fractures consist of closed natural, mineralized, and slickensided fractures. The Onondaga Formation and Huntersville Chert were cored beneath the Marcellus Formation. The Onondaga consisted of 13.15 feet $(4 \mathrm{~m})$ of medium gray limestone, sometimes argillaceous in nature or containing a skeletal matrix (packstone to wackestone), interbedded with dark-gray calcareous shale and ash beds. Organic matter and clay content are low, while carbonate content is high. Abundant fossils in the form of brachiopods shells and crinoids, with bioturbation that ranges from moderate to strong. Mineralized fractures are abundant, especially within the limestone intervals. The Onondaga and Huntersville Chert are separated by 1.2 feet $(0.37 \mathrm{~m})$ of gray glauconitic shale (Fig. 5.8). The Huntersville Chert is 1.85 feet $(0.56 \mathrm{~m})$ thick, mottled, bluish-gray massive chert. Mineralized calcareous fractures are evident but otherwise the chert is non-calcareous. Mottled appearance is due to intense bioturbation in original rock. Sequence boundaries were best identified by using the gamma ray (GR) log. In the core, sequence boundaries were often described as gradational contacts. For instance, the upper and 
lower Marcellus contact with the Purcell Member (Fig. 5.7) was gradational and identified by an increase in calcareousness and biogenic components. Alternatively, the contact between the Onondaga - lower Marcellus was sharp and at a low angle to the bedding plane (Fig. 2.5). The argillaceous limestone of the Onondaga transitioned abruptly into a dark calcareous shale with thin interbeds of argillaceous limestone at the basal part of the lower Marcellus.

The types of fractures in the core were noted in the core description and on the graphic log. However, a quantitative examination of fracture description and intensity for the cored interval was conducted by Core Lab (Table 5.1). There are two types of fractures in this core: closed, slickensided fractures and mineralized fractures (Fig. 5.9). Vertical and horizontal mineralized fractures are considerably more abundant than the slickensided fractures. Fracture intensity is the highest in the Onondaga Formation followed by the upper Marcellus, Purcell Limestone, lower Marcellus, and Mahantango. The total fracture intensity for the whole Marcellus Formation is 0.97 fractures/feet. Slickensided fractures are found in the abundance at the very bottom of the lower Marcellus, in dense calcareous zone just above the Onondaga Formation. The mineralized fractures are typically filled with calcite and tend to be associated with calcareous concretions and calcareous zones. 


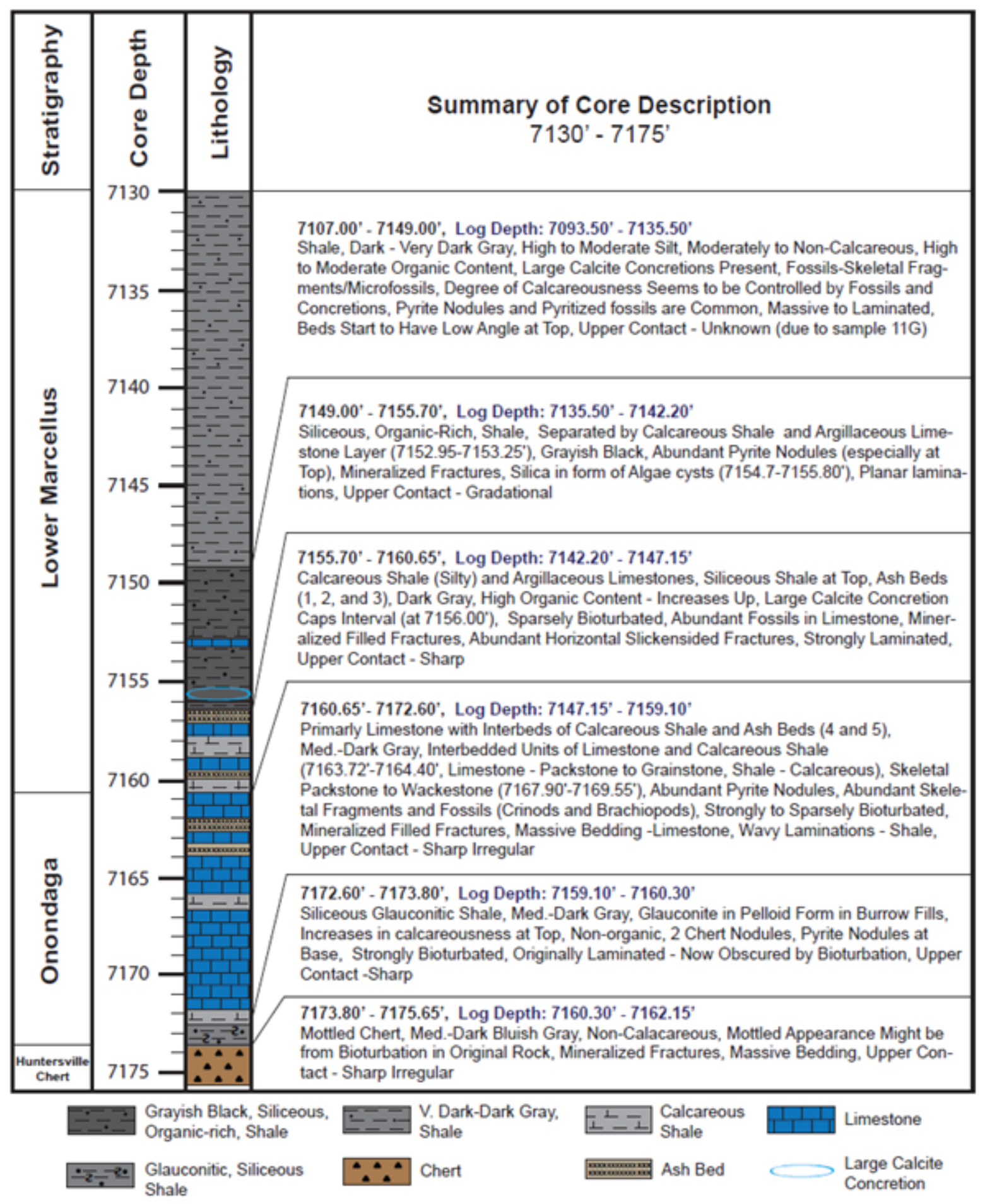

Figure 5.2. Summary of core description for the Huntersville Chert, Onondaga, and Lower Marcellus Formations, extending from 7130 to $7175.65 \mathrm{ft}$. in core depth, and from 7116.50 to $7162.15 \mathrm{ft}$. in $\log$ depth. 


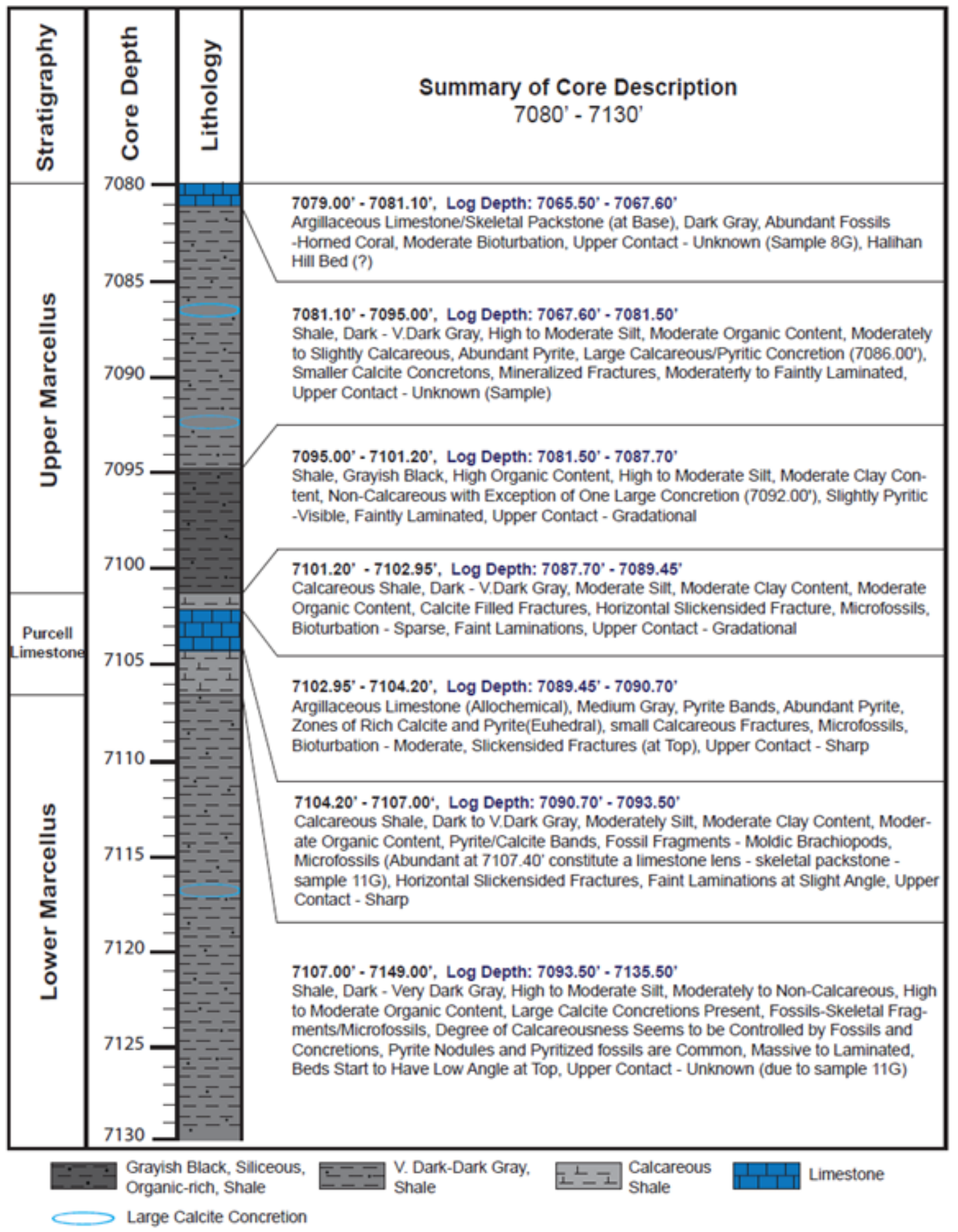

Figure 5.3. Summary of core description for the top part of the Lower Marcellus, Purcell Limestone, and bottom part of upper Marcellus, extending from 7080 to $7130 \mathrm{ft}$. in core depth, and from 7066.50 to $7116.50 \mathrm{ft}$. in log depth. 


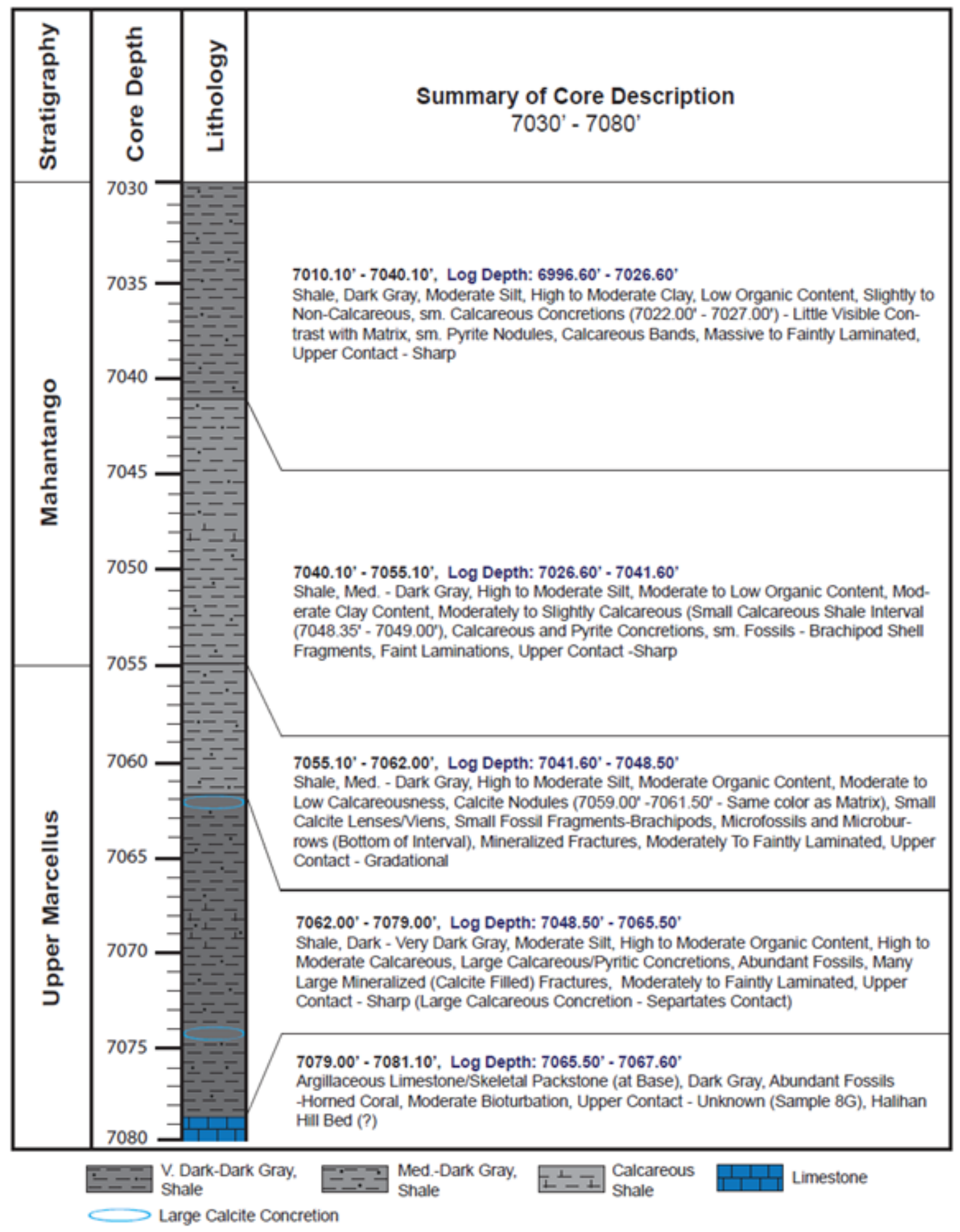

Figure 5.4. Summary of core description for the top part of the upper Marcellus and Mahantango Formation, extending from 7030 to $7080 \mathrm{ft}$. in core depth, and from 7016.50 to $7066.50 \mathrm{ft}$. in log depth. 


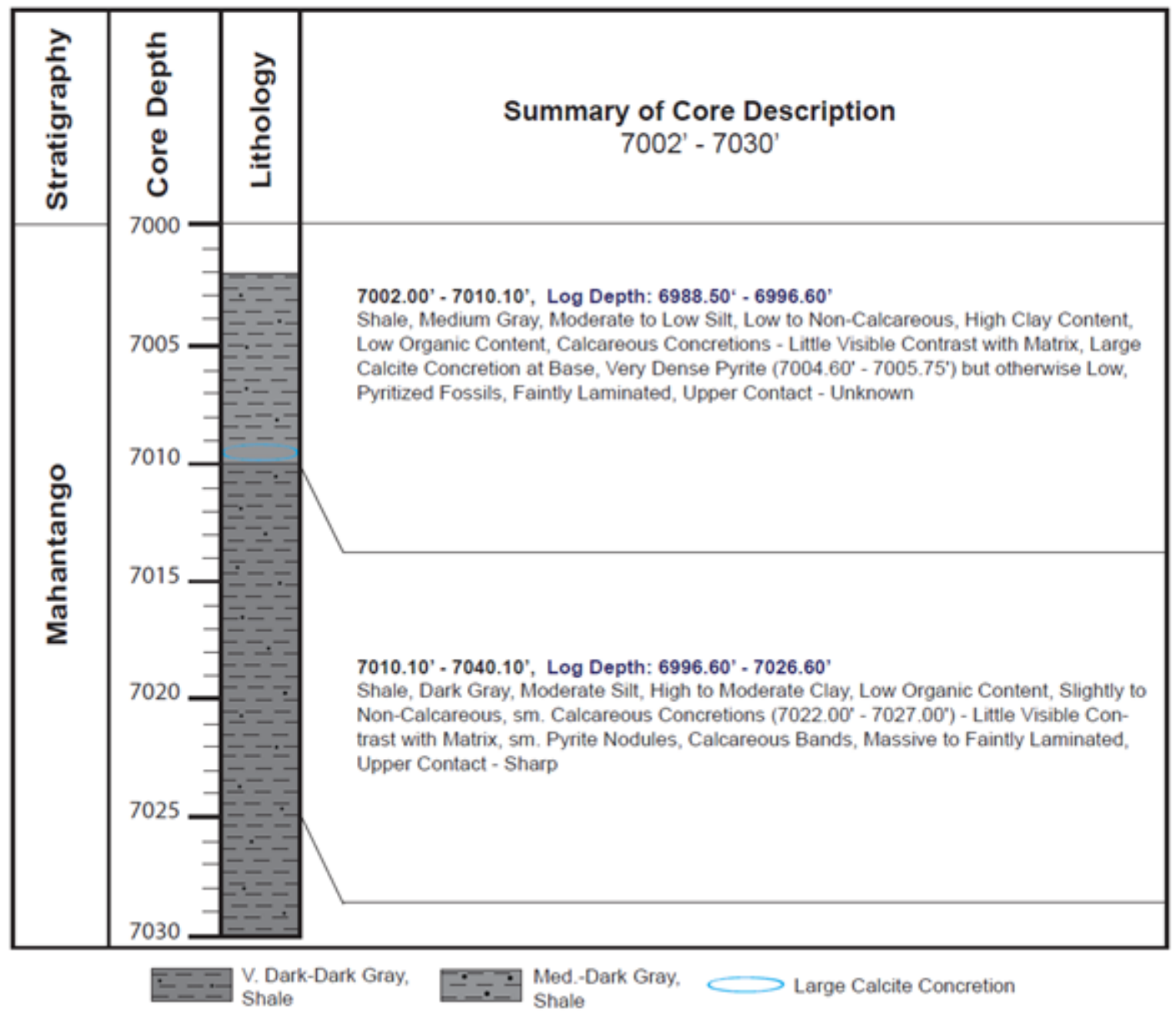

Figure 5.5. Summary of core description for the remainder of the cored Mahantango Formation, extending from 7002 to $7030 \mathrm{ft}$. in depth, and from 6988.50 to $7016.50 \mathrm{ft}$. in log depth. 


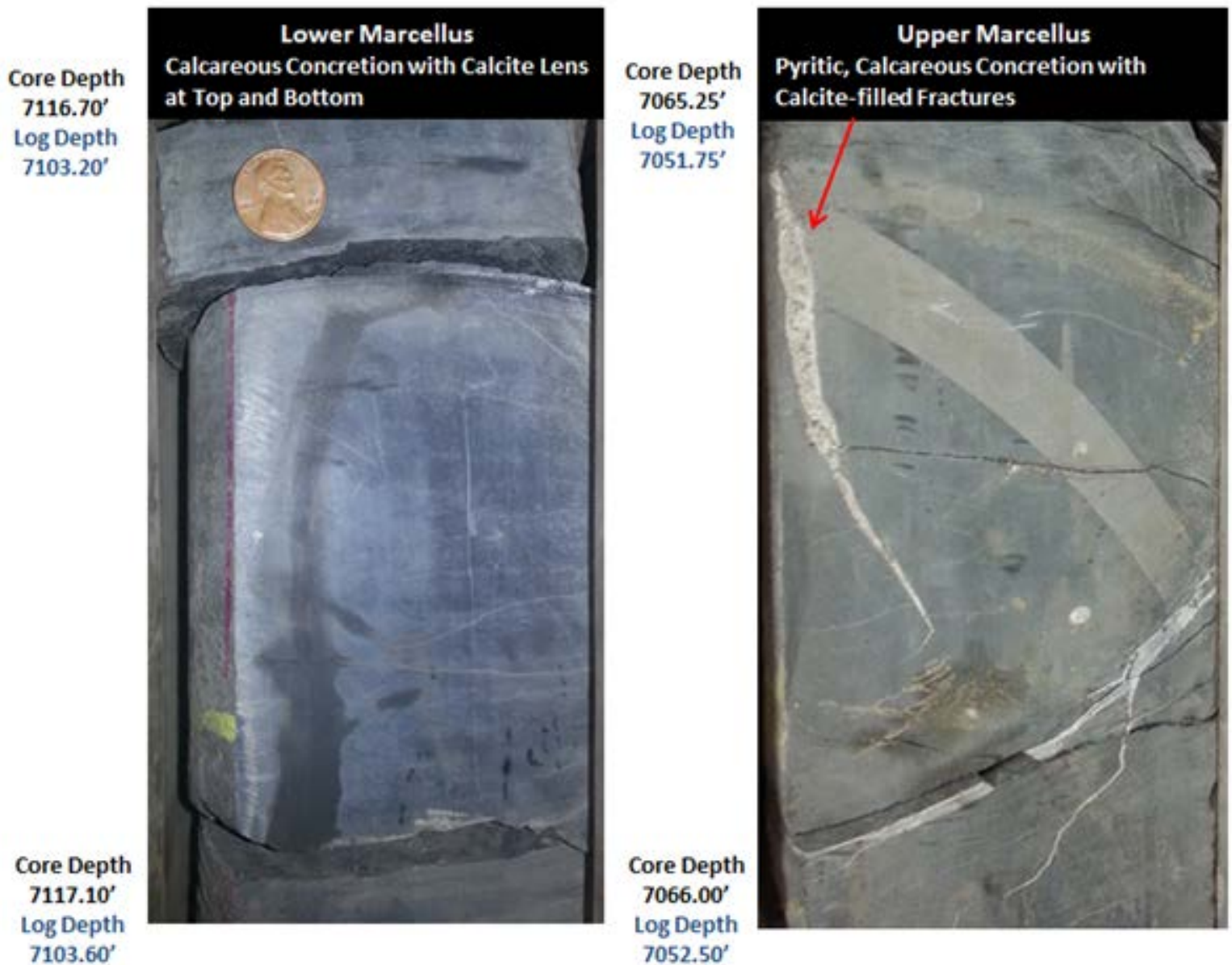

Figure 5.6. Visual image of the large calcareous concretions found in the lower (left) and upper (right) Marcellus. The concretion on the right is also pyritic and is associated with calcite filled fractures that cross cut the pyritic bands. The concretion in the lower Marcellus has calcite lenses on its upper and lower limits. Furthermore, due to the large size of these calcareous concretions, they are noted in the gamma ray response. 


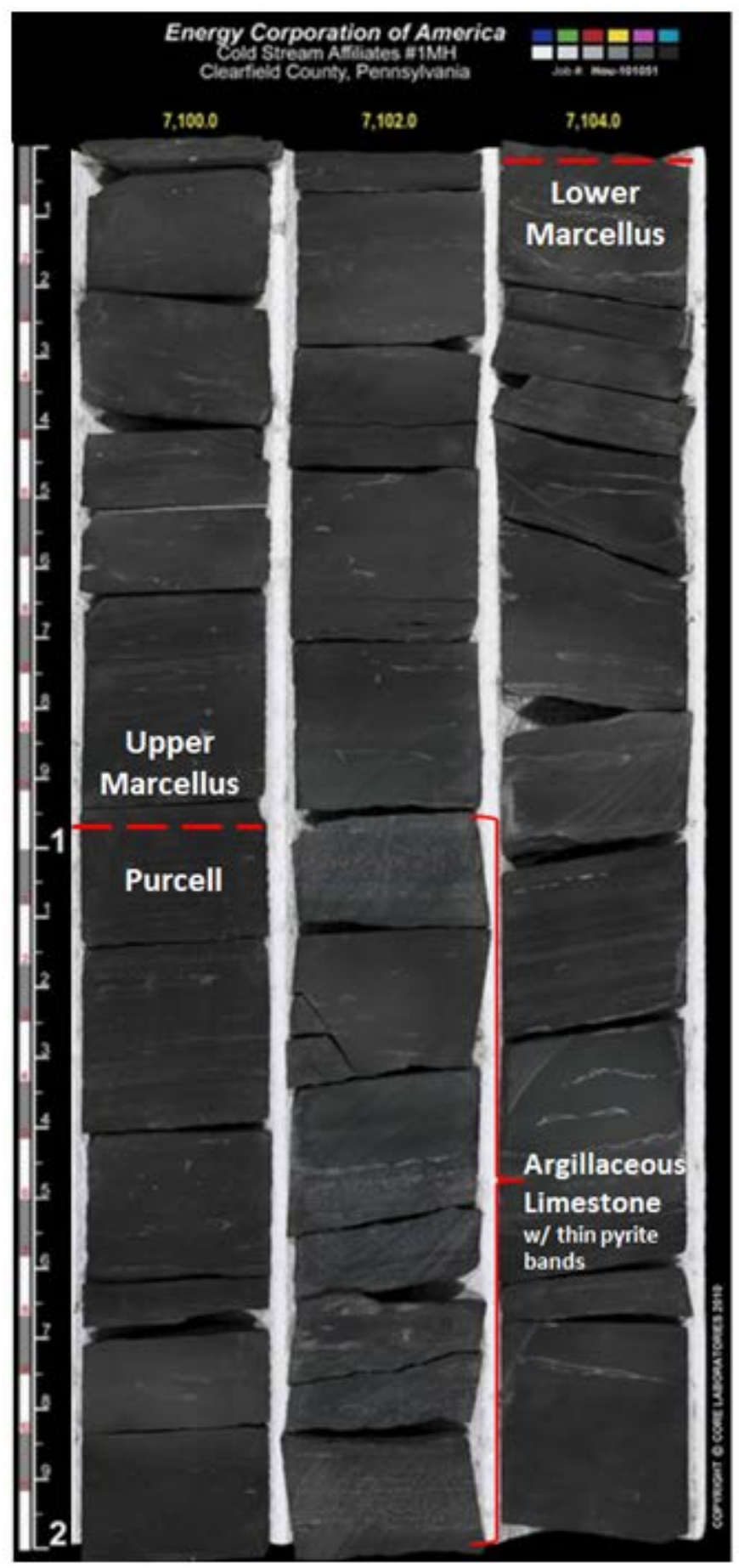

Figure 5.7. This figure shows the Purcell Limestone as well as the upper and lower Marcellus contacts (red dashes). The Purcell limestone consists of an allochemical, argillaceous limestone interval, with abundant pyrite, microfossils, and moderate bioturbation, that is bounded above by a calcareous shale interval. 


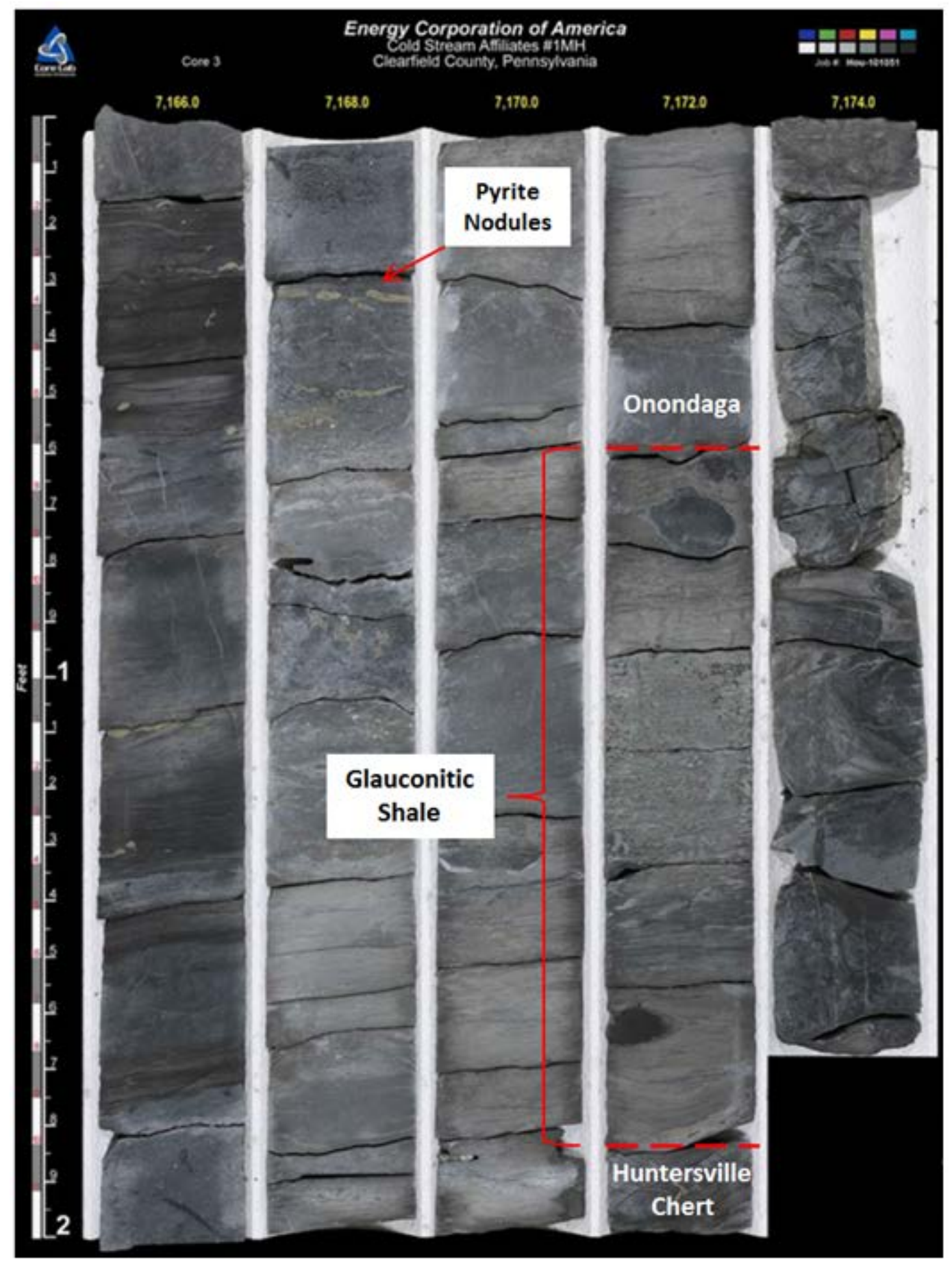

Figure 5.8. This image illustrates the glauconitic, siliceous shale located between the Onondaga Limestone and Huntersville Chert (red dashes). 


\begin{tabular}{|c|c|c|c|c|c|}
\hline \multicolumn{6}{|c|}{ FRACTURE DESCRIPTION AND INTENSITY FOR COLDSTREAM \#1MH CORE } \\
\hline \multicolumn{2}{|c|}{$\begin{array}{l}\text { FORMATION NAME or } \\
\text { EQUIVALENT }\end{array}$} & $\begin{array}{c}\text { CLOSED } \\
\text { FRACTURES }\end{array}$ & $\begin{array}{l}\text { MINERALIZED } \\
\text { FRACTURES }\end{array}$ & $\begin{array}{c}\text { TOTAL } \\
\text { NATURAL } \\
\text { FRACTURES }\end{array}$ & $\begin{array}{c}\text { FRACTURE } \\
\text { INTENSITY } \\
\text { (Fractures/Feet) }\end{array}$ \\
\hline \multicolumn{2}{|c|}{ Mahantango } & 10 & 33 & 43 & 0.40 \\
\hline \multirow{3}{*}{ Marcellus } & Upper Marcellus & 16 & 96 & 112 & 1.21 \\
\hline & $\begin{array}{c}\text { Purcell } \\
\text { Limestone }\end{array}$ & 3 & 4 & 7 & 1.17 \\
\hline & Lower Marcellus & 32 & 53 & 85 & 0.75 \\
\hline \multicolumn{2}{|c|}{ TOTAL MARCELLUS } & 51 & 153 & 204 & 0.97 \\
\hline \multicolumn{2}{|c|}{ Onondaga } & 0 & 79 & 79 & 3.00 \\
\hline
\end{tabular}

Table 5.1. The table above shows the fracture types and intensity for the cored well. In the Marcellus, the fracture intensity is higher in the upper Marcellus, while the Onondaga has the highest fracture intensity of all the formations. 


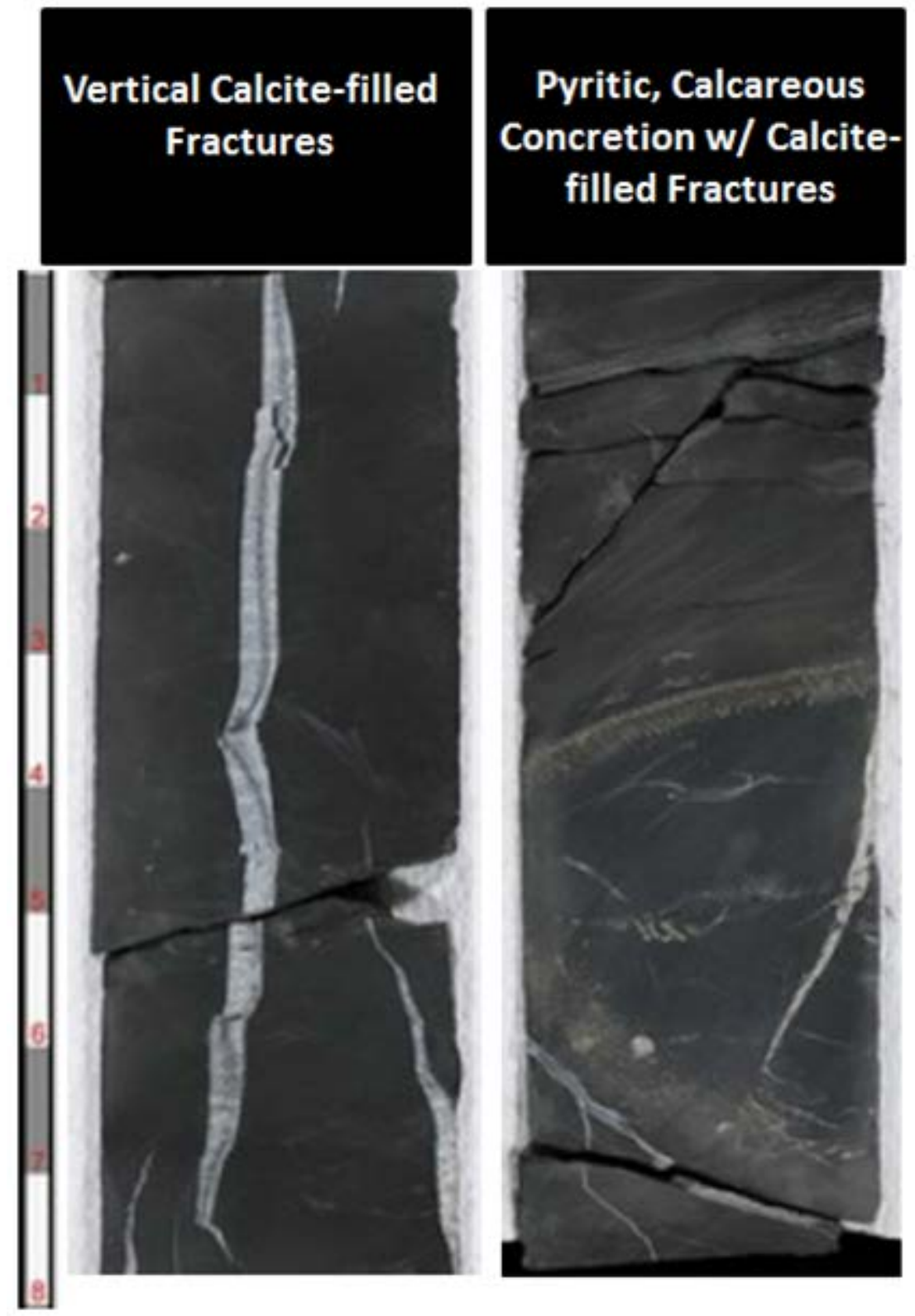

Figure 5.9. Mineralized, vertical fractures are the most abundant fracture type. They are typically filled with calcite and associated with calcareous concretions and the more calcareous zones. 


\subsubsection{Thin-Section Description}

The thin-section images for the Coldstream \#1MH well were provided by Core Lab at 17 locations throughout the cored interval. XRD and TOC were collected at these locations as well, to insure an accurate, truly representative illustration of the sample to be incorporated into the lithofacies description (see chapter 6). At each of the 17 sample locations, four images were taken with three $(\mathrm{A}, \mathrm{B}$, and $\mathrm{C})$ of the four images being of a $30-\mu \mathrm{m}$-thick portion of thin-section, while image $\mathrm{D}$ is a view of the ultra-thin portion designed to reveal silt grains (Fig. 5.10-5.12). Image $\mathrm{B}$ is a view of image $\mathrm{A}$ under epifluorescent light to show induced fractures. Image $\mathrm{C}$ is taken under finer magnification $0.1 \mathrm{~mm}$ instead of $0.5 \mathrm{~mm}$.

The thin-section images (Fig 5.10) at $7155.50 \mathrm{ft}$. (LM-2) and $7128.00 \mathrm{ft}$. (LM-5)

illustrates the petrographic differences between the lower and upper parts of the lower Marcellus. Thin-section images of sample LM-2 show darker, more organic content, higher silt content with most silt size grains being quartz, and TOC is high at 8.25 wt. \%. Image $\mathrm{C}$ shows long elongate grains of polycrystalline quartz, which was interpreted by Core Lab to be silicified algal cysts. Thin faint lamination is present but it is not as strong or thick as lamination in sample LM-5. The laminations in sample LM-5 have variable amounts of silt, carbonate, and clay, with more carbonate and clay content then LM-2. Organic content is moderate with TOC at 4.38 wt. \%. Scattered skeletal fragments and silt filled burrows are also presents in this sample.

The thin-section images of the upper Marcellus (Fig. 5.11) at $7099.50 \mathrm{ft} .(\mathrm{UM}-8)$ and $7070.00 \mathrm{ft}$. (UM-11) contains more clay and overall less silt and organic matter than the lower Marcellus. Sample UM-8 is an organic-rich shale, with high clay content as seen in abundant illite blebs and compacted clay filled burrows. Image $\mathrm{C}$ shows calcified algae cysts, which were identified by Core Lab, and TOC is $7.28 \%$ Sample UM-11 is a dark-gray calcareous shale that contains abundant skeletal fragments of ostracods and brachiopods. Image $\mathrm{C}$ shows a bedding 
plane that is made apparent by color contrast indicative of changes in organic material, while image D captured some larger silt grains and organic material in the form of faint discontinuous streaks. Despite the presence of organic matter, the TOC is fairly low at 2.33 wt. $\%$.

The Mahantango Formation is exemplified in sample MAH-15 at $7028.00 \mathrm{ft}$ (Fig. 5.12). Sample MAH-15 is a gray shale, where silt and clay are moderate in content; it is essentially non-calcareous, silty laminations are present, as well as potentially compacted clay burrows and illite blebs. In image D, framboidal pyrite is evident but overall pyrite is not abundant. The TOC for this sample is low at $2.62 \mathrm{wt} . \%$.

While a quick visual assessment of the shale samples appears to be relatively similar, with minor changes in color, texture, mineralogy, and TOC, the Onondaga Limestone is significantly different from the other thin-section images. The Onondaga limestone, sample ON1 at 7165.00 feet (Fig. 5.12), is a massive skeletal packstone that has been recrystallized. Calcite is the dominant mineral, as it fills mineralized fractures and makes up the majority of the matrix for this sample. Image A shows a possible burrow that is crosscut by a healed, mineralized fracture. 


\section{Lower Marcellus}

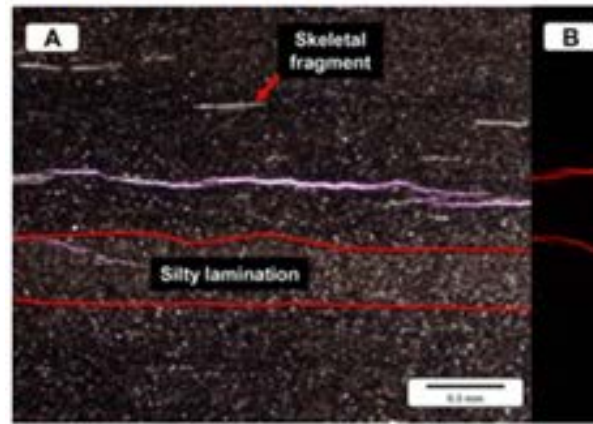

Core Depth: 7128.00', Log Depth: 7114.50'

\section{Sample ID: LM-2}

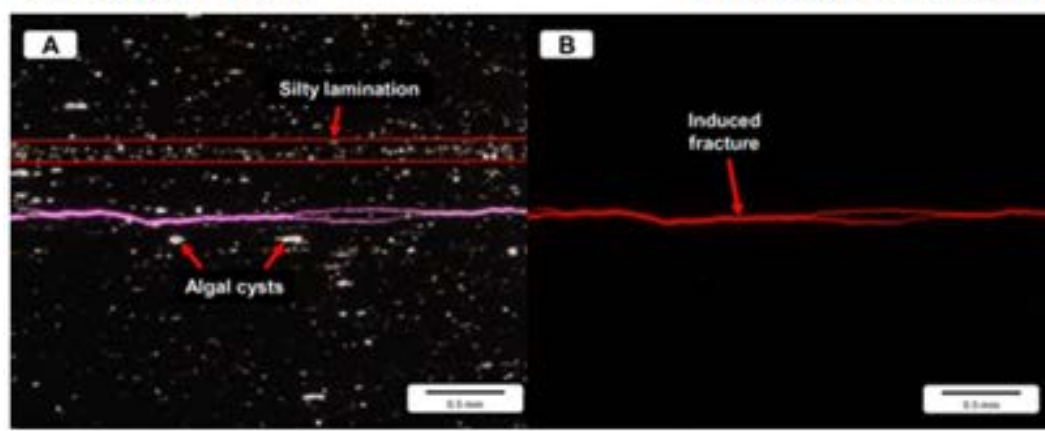

Core Depth: 7155.50', Log Depth: 7142.00'
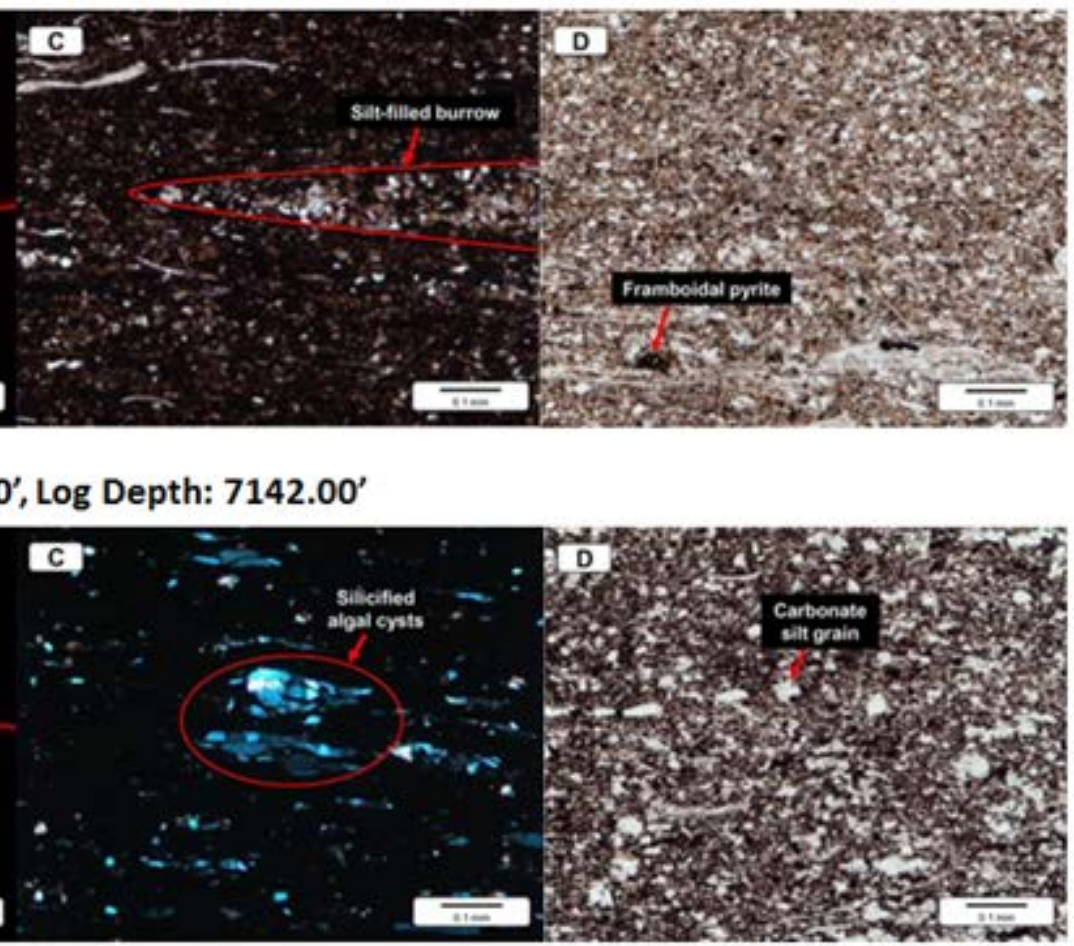

Figure 5.10. Thin-section images of the lower Marcellus. LM-2 (bottom) shows a darker, more siliceous and organic-rich shale, with silicified algal cysts, thin laminations, silt size quartz grains, and a TOC of $8.25 \mathrm{wt}$ \%. LM-5 (top) is shale located in the top part of the lower Marcellus. It is lighter and less organically-rich (TOC of $4.38 \mathrm{wt}$ \%), with more carbonate and clay content. Laminations are larger with variable amounts of silt, carbonate, and clay, and scattered skeletal fragments and silt filled burrows. (Sample ID used in table of XRD and TOC results, see appendix). Images A, B, and C are of a 30- $\mu$ m-thick portion of thin-section, while image D is a view of the ultra-thin portion designed to reveal silt grains. Image B is a view of image A under epifluorescent light to show induced fractures. Image A and B are taken under a resolution of $0.5 \mathrm{~mm}$, while Image C and D are taken under a finer resolution of $0.1 \mathrm{~mm}$. 


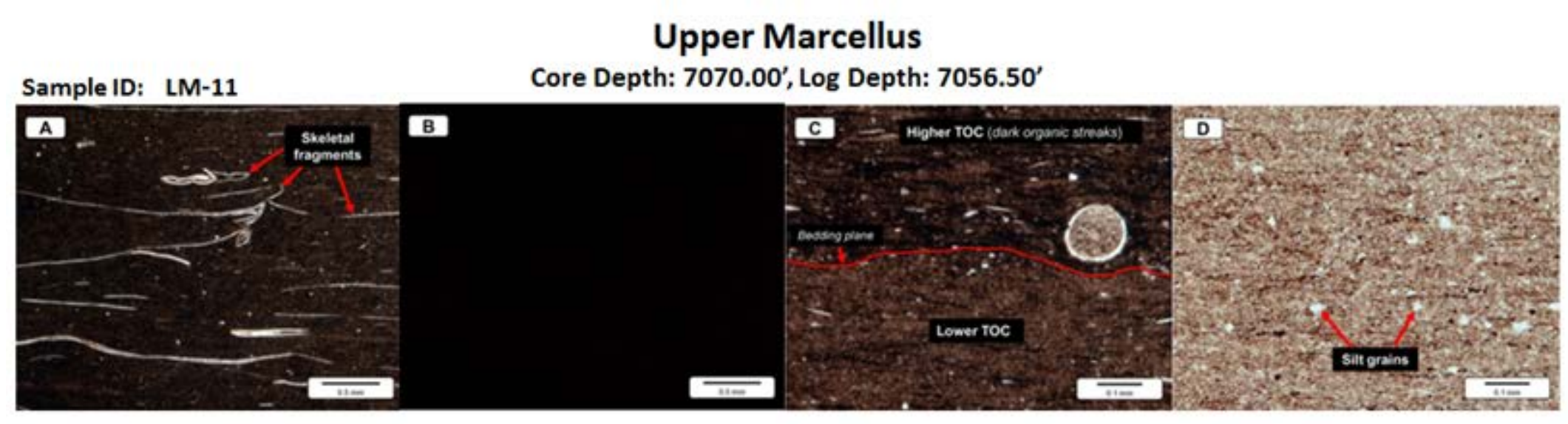

\section{Sample ID: LM-8}

Core Depth: 7099.50', Log Depth: 7086.00'

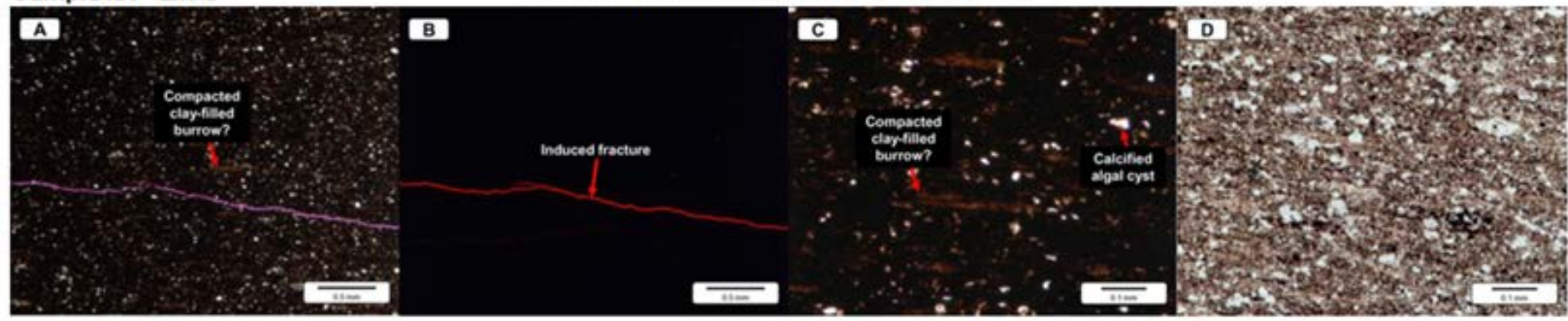

Figure 5.11. Thin-section images of the upper Marcellus LM-8 (bottom) and LM-11(top). Overall these thin-sections consist of more clay and lower silt and organic matter than the lower Marcellus. LM-8 shows a darker, more siliceous and organic-rich shale, with calcified algal cysts and compacted clay filled burrows. TOC is $7.28 \mathrm{wt}$ \%. LM-5 is a gray calcareous shale that contains abundant skeletal fragments of ostracods and brachiopods. TOC is low at $2.33 \mathrm{wt}$. \%, with image $\mathrm{C}$ showing a color contrast that is indicative of change in organic material. (Sample ID used in table of XRD and TOC results, see appendix). Images A, B, and C are of a 30- $\mu$ mthick portion of thin-section, while image $\mathrm{D}$ is a view of the ultra-thin portion designed to reveal silt grains. Image $\mathrm{B}$ is a view of image A under epifluorescent light to show induced fractures. Image A and B are taken under a resolution of $0.5 \mathrm{~mm}$, while Image $\mathrm{C}$ and $\mathrm{D}$ are taken under a finer resolution of $0.1 \mathrm{~mm}$. 


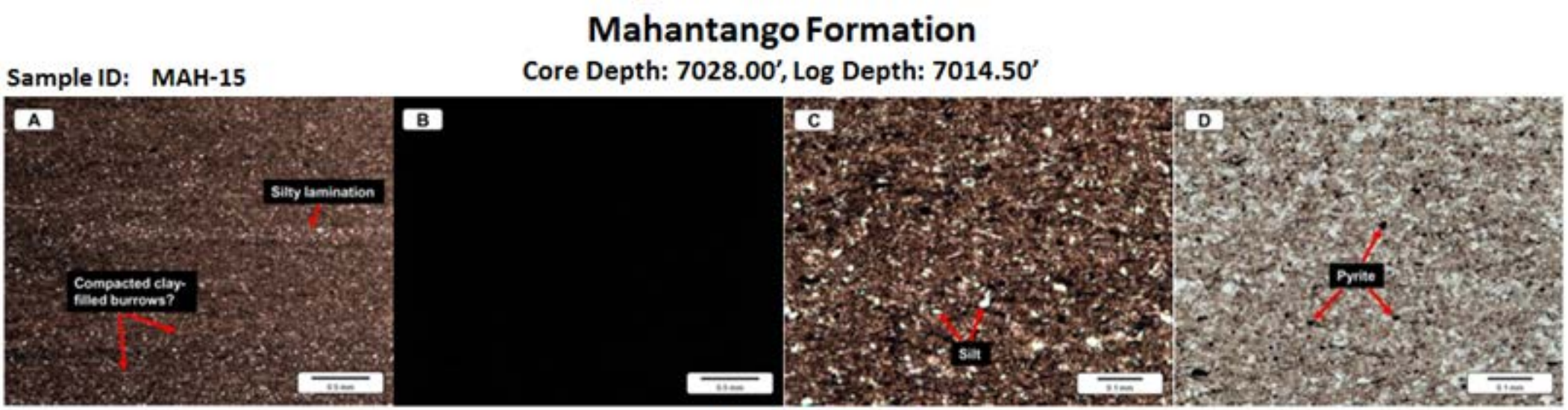

Onondaga Formation

Sample ID: ON-1 Core Depth: 7165.00', Log Depth: 7151.50'

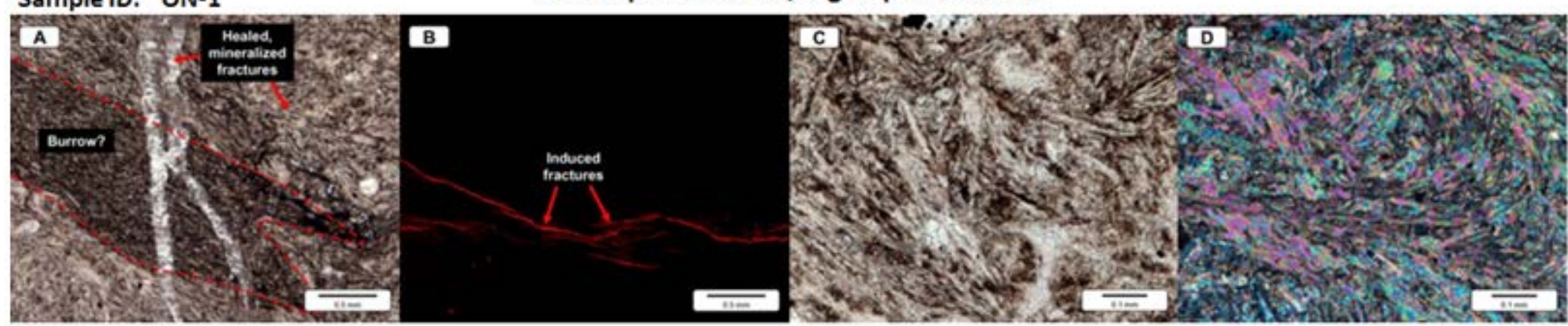

Figure 5.12. Thin-section images of Mahantango and Onondaga Formations. The Onondaga, ON-1 (bottom) is a massive skeletal packstone that has been recrystallized. Calcite is the dominant mineral and it fills fractures and makes up the majority of the matrix. Image A shows a possible burrow that is cross-cut by a healed, mineralized fracture. The Mahantango, MAH-15 (top) is gray shale, with moderate clay and silt. Silty laminations are present as well as potentially compacted clay burrows and illite blebs. (Sample ID used in table of XRD and TOC results, see appendix). Images A, B, and C are of a 30- $\mu$ m-thick portion of thin-section, while image $\mathrm{D}$ is a view of the ultra-thin portion designed to reveal silt grains. Image $\mathrm{B}$ is a view of image A under epifluorescent light to show induced fractures. Image A and B are taken under a resolution of $0.5 \mathrm{~mm}$, while Image C and D are taken under a finer resolution of $0.1 \mathrm{~mm}$. 


\subsection{Quantitative Interpretation}

\subsubsection{Mineralogical Modeling}

In order to determine the mineralogy of the cored well, mineral weight percentages were determined using XRD methods. There were 59 XRD samples total, 17 of those samples were collected and analyzed at Core Lab, the remainder were taken at WVU and powdered for analysis. The mineralogy by depth graph along with ternary diagrams were used to illustrate XRD results. Shuvajit Bhattacharya generated a mineralogical model using the Statmin module in PowerLog, which was used to supplement the inconsistency of the XRD data. Mineralogical evaluation is used for lithofacies identification, and subsequently for understanding the depositional environment.

The XRD samples analyzed at WVU were conducted using the PANalytical X'Pert PRO XRD instrument at WVU's Shared Research Facility. Interpretation of the XRD patterns was determined using PANalytical X'Pert HighScore Plus software, selecting mineral type through a compositional dataset. XRD results are displayed as a series of peaks that correspond to different mineral patterns (Fig 5.13). The user creates a mineral list based on the minerals she/he believes to be present in the samples. For consistency, the mineral list does not change throughout the interpretation period. The samples in this study were analyzed for quartz, pyrite, calcite, dolomite, and illite, since analysis of previous Marcellus core samples (Boyce, 2010) have shown abundance of these minerals with a clay content consisting of primarily illite. Other clay minerals, such as kaolinite and smectite, caused an interference with the quartz and carbonate peaks during analysis and were excluded from the mineral list. 


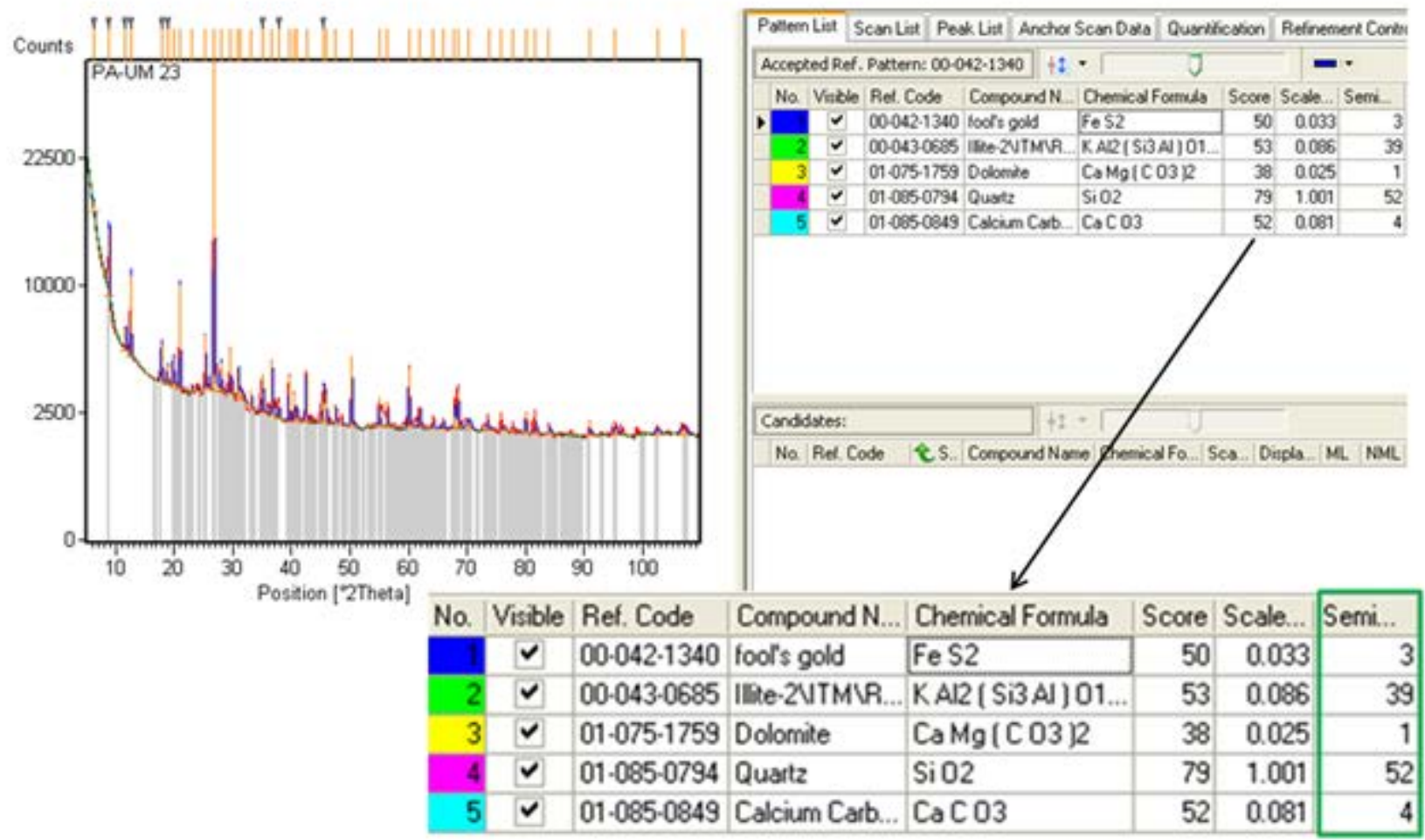

Figure 5.13. PANalytical $X$ 'Pert HighScore Plus software matching raw peaks to mineral patterns based on the user defined mineral list. Mineral weight percentages for this sample (green box) contains $3 \%$ pyrite, $39 \%$ illite, $1 \%$ dolomite, $52 \%$ quartz, and $4 \%$ calcite.

Core Lab analyzed 17 samples for XRD by performing a bulk analysis on all mineral components (quartz, k feldspar, plagioclase, calcite, dolomite, pyrite, kerogen, and total clay) and a separate clay size fraction that includes types and amounts of clay minerals. Unfortunately, the XRD software at WVU's Shared Research Facility is not as advanced as the software Core Lab has for XRD analysis. In order to compensate for the inconsistency in software, the mineral percentages for the feldspars were added to quartz percent. While illite percent was considered to be the total clay, since other clay types caused an interference.

Complete results for XRD are located in the appendix A. Figure 5.14 illustrates the mineralogy in relation to the stratigraphy and depth for the cored well. The overall results of XRD show that the 
lower Marcellus has more quartz than the upper Marcellus, while clay percent is slightly higher in the upper Marcellus (Fig. 5.15). The carbonate minerals, calcite and dolomite, are fairly similar, with the upper Marcellus having a slightly higher pyrite percent. The ternary diagrams (Fig. 5.16), for the lower and upper Marcellus, are normalized for quartz, clay, and carbonate and related to spectral core GR. The results are consistent with XRD data regarding clay and quartz in the upper and lower Marcellus. Since Core Lab's XRD software is more advanced, there are clay mineral percentages for the separate clay size fraction for the 17 XRD samples. The clay minerals consisted of mixed layer illite/smectite, illite and mica, as well as chlorite. Illite and mica were the most abundant clay type followed by chlorite (Fig. 5.17). These results are consistent with the $\mathrm{Th} / \mathrm{K}$ ratio curve (Fig. 5.21 and 5.22, track 2) and are consistent with expected clay type in high to post mature formations.

Due to the scarcity of core XRD points, a stochastic mineralogical model (Fig. 5.18) was used for comparison purposes and to supplement the XRD data down to a log depth of $7113.50 \mathrm{ft}$. (core depth of $7127.00 \mathrm{ft}$. .). A statistical multi-mineral solution was obtained using four different well logs: core GR, corrected neutron porosity, corrected bulk density, and the Umaa log, which is the product of bulk density and photoelectric absorption. Neutron porosity was converted from a sandstone matrix to a limestone matrix, in addition to being corrected for wash out zones that are indicated by higher caliber readings. The output solution is comprised of 8 log curves: quartz, smectite, illite, calcite, dolomite, kerogen, pyrite, and bulk volume of water "final" (Shuvajit Bhattacharya, Pers. Comm, 2015).

The mineralogical model (Fig. 5.18) is relatively consistent with the sample based results of XRD (Fig. 5.14) for the cored well. The mineralogical model shows overall a greater abundance of quartz than clay percent. Carbonate percent is low overall, especially in comparison to other study wells in the basin (Shuvajit Bhattacharya, Pers. Comm, 2015), with the exception of the Onondaga Formation. However, there seems to be a discrepancy in the data relative to clay type. Clay type was determined 
via $\mathrm{XRD}$, mineralogical model, and spectral core gamma ray (GR). The clay XRD results from the Core Lab showed a very small percent of mixed layer clay and relatively no smectite at the 17 sample locations, while the mineralogical model appears to have almost equal parts illite and smectite. Furthermore, it should be noted that mineralogical models of other study wells show predominately illite in the Marcellus Formation. Spectral core GR data, in the $\mathrm{Th} / \mathrm{K}$ curve shows illite as the dominant clay type at the base of the lower Marcellus, where the formation is expected to be more thermally mature. Alternatively, the $\mathrm{TH} / \mathrm{K}$ crossplot (Fig. 5.2) shows clay type that ranges from illite to mixed layer clay to smectite for the Marcellus and Mahantango formations. The significance for determining clay type is to understand the degree of diagenesis, which relates to greater thermal maturity and potentially a more organic-rich source rock. 


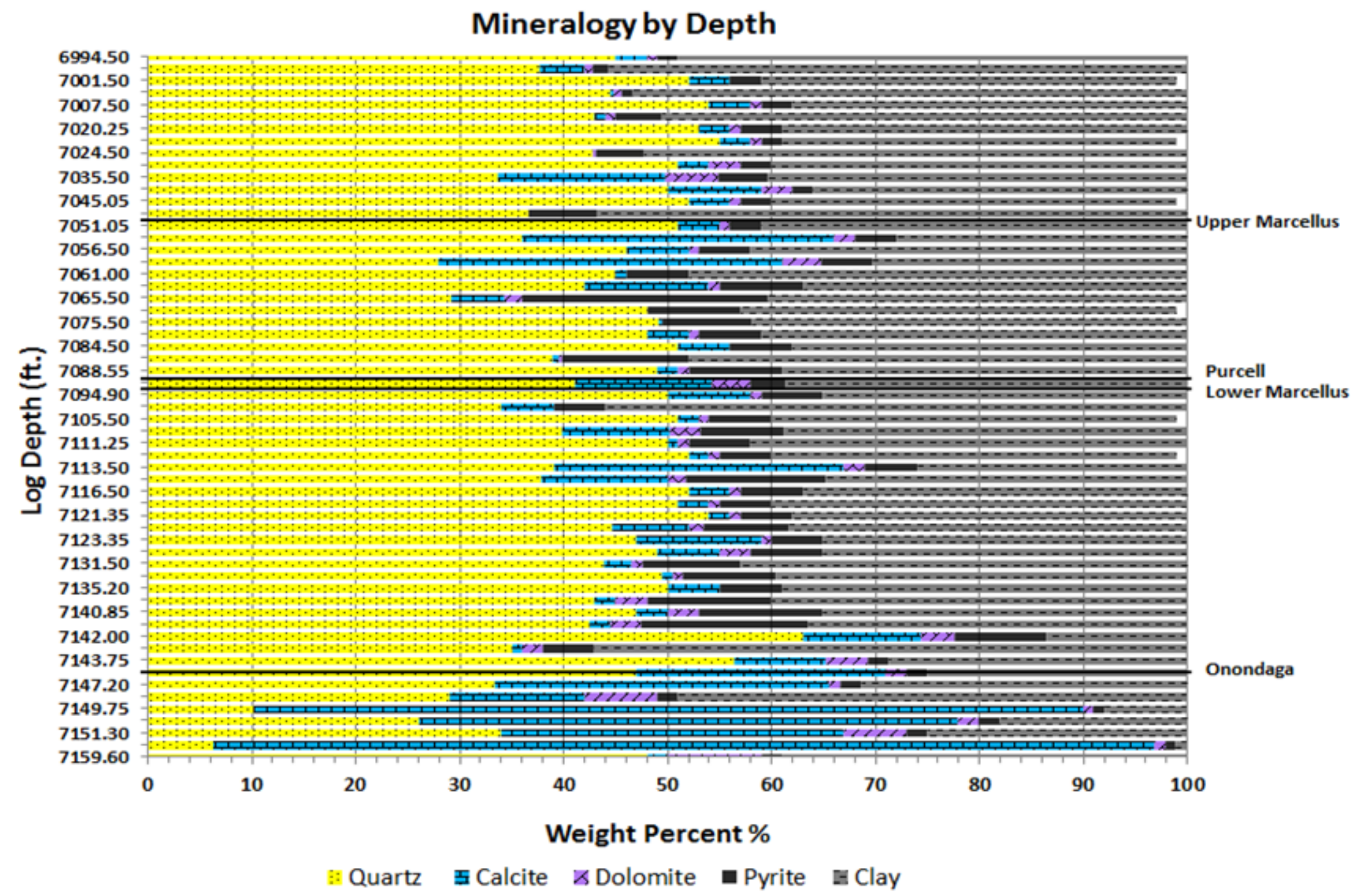

Figure 5.14. The graph illustrates the mineral weight percentages by depth from the XRD results for quartz, calcite, dolomite, pyrite, and clay. Quartz also includes plagioclase and $\mathrm{K}$ feldspars. 

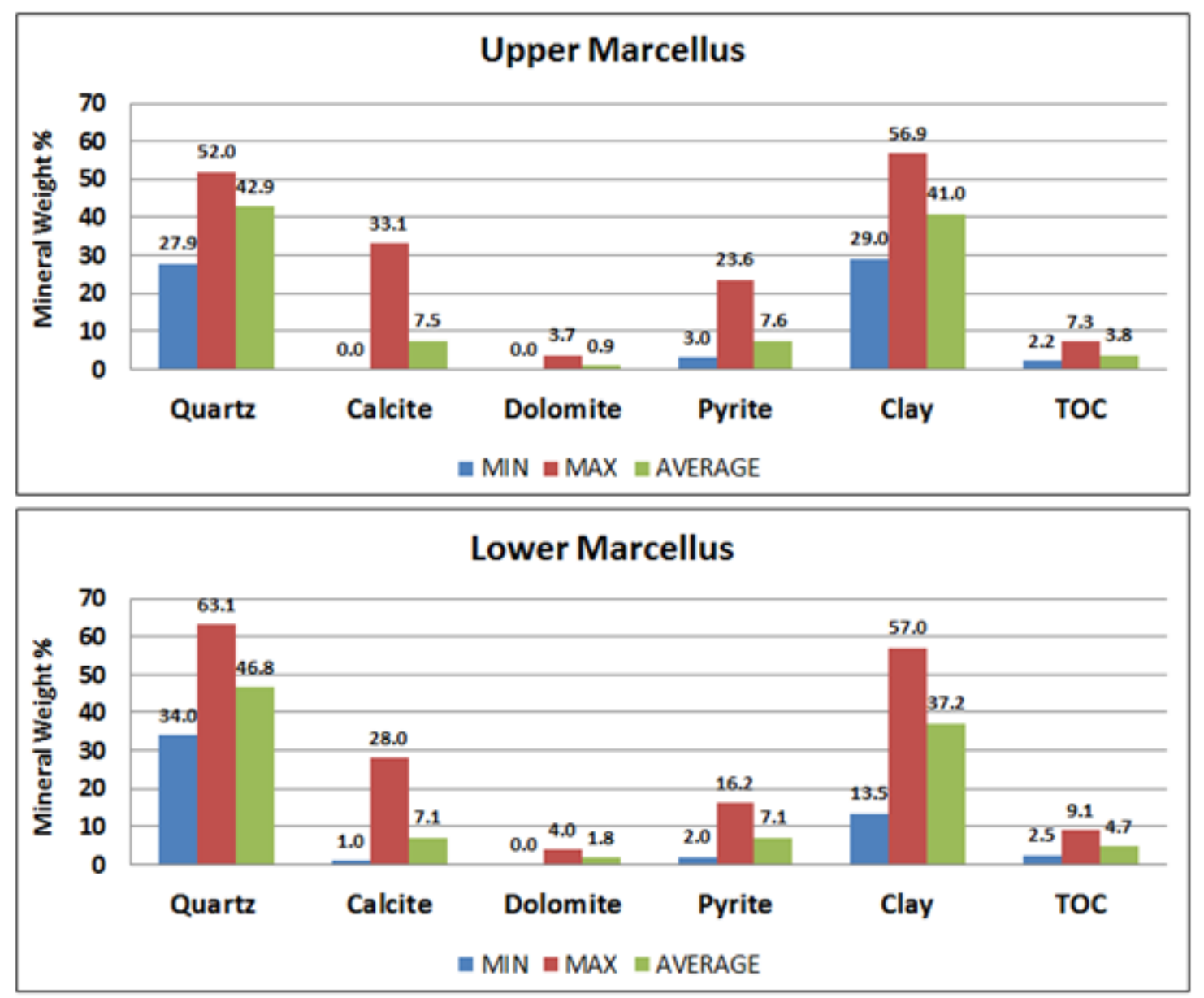

Figure 5.15. The graphs of the lower (bottom) and upper (top) Marcellus illustrates the minimum, maximum, and average weight percentages for quartz, calcite, dolomite, pyrite, clay, and TOC. Mineralogical comparison between the units shows that the lower Marcellus on average has higher quartz and TOC, with lower calcite and pyrite. The average clay weight percent is relatively equal but the minimum and maximum values for clay in the lower Marcellus are less, which is consistent with core and thin-section interpretation. 


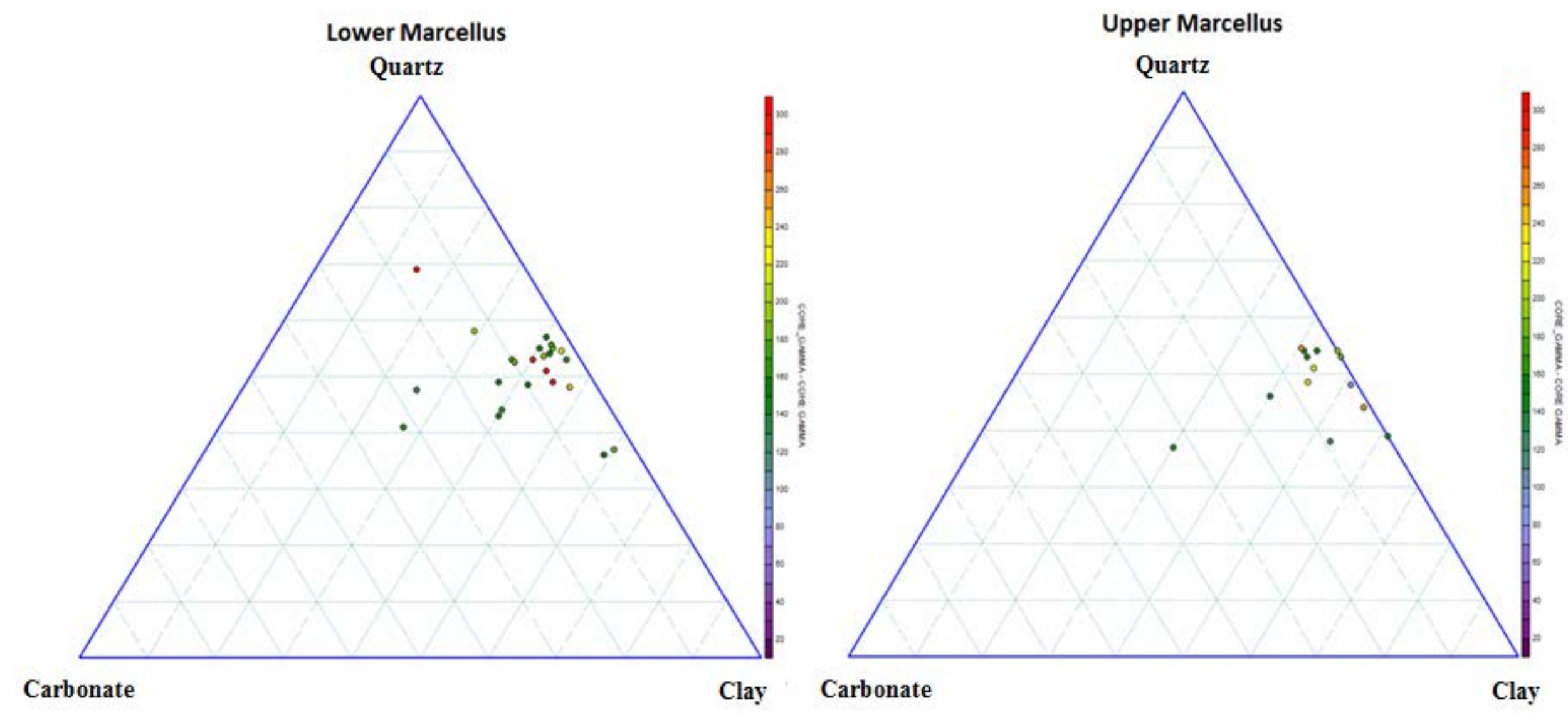

Figure 5.16. The ternary diagrams illustrate recalculated $X R D$ clay, quartz, and carbonate percent relative to gamma ray (GR) response for the lower (left) and upper (right) Marcellus. Quartz is combined with the small percent of plagioclase and K feldspars, while carbonate consists of both calcite and dolomite. These diagrams show that the mineralogy between the lower and upper Marcellus are fairly similar, with the lower Marcellus having slightly more quartz and higher GR response than the upper Marcellus. 


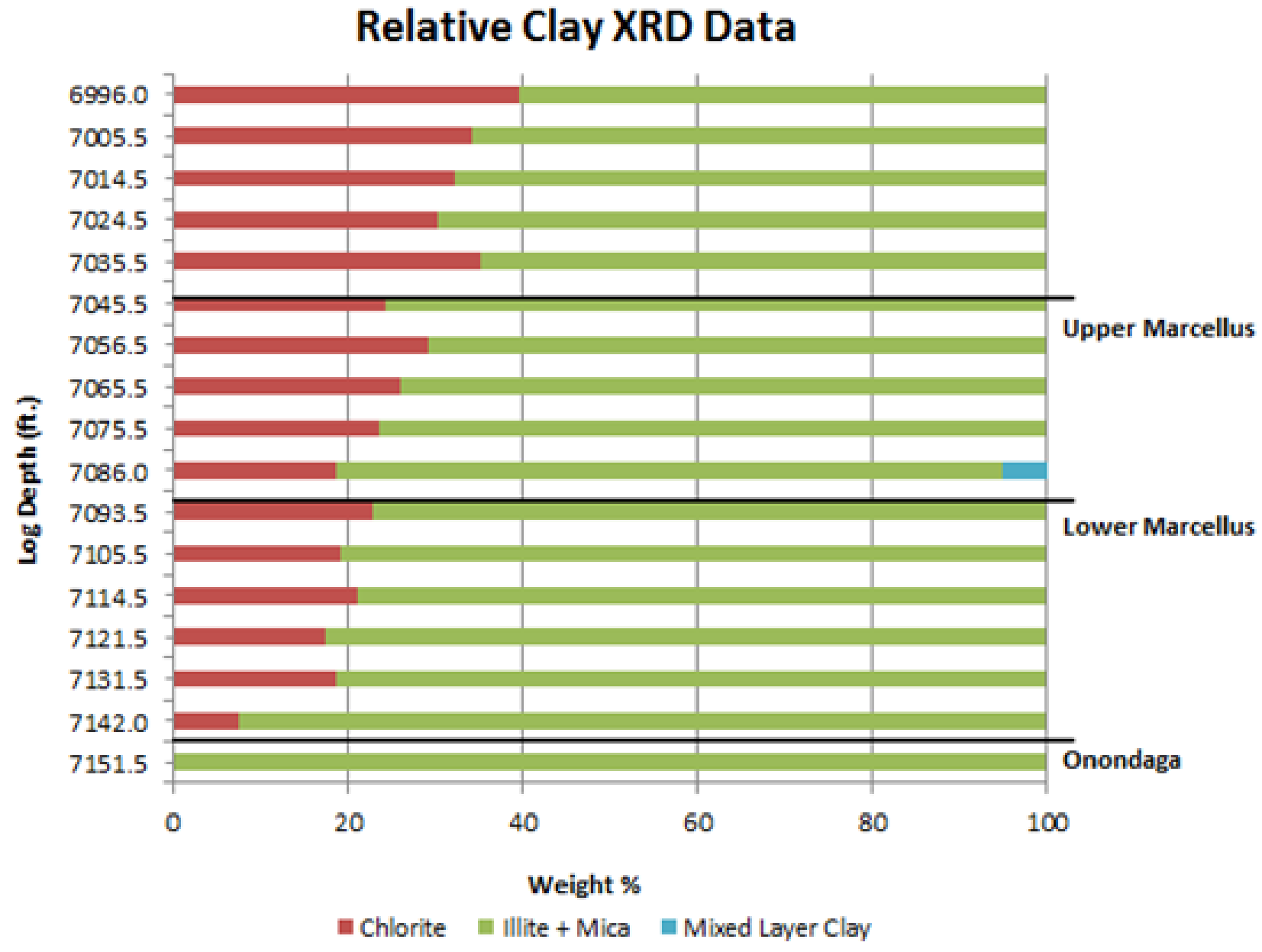

Figure 5.17. Relative clay XRD data determined from the total clay weight percent. Illite and mica are abundant and decrease upwards, while chlorite increases in percent upwards. Only a small percent of mixed layer clay is found in the upper Marcellus at a log depth of $7086 \mathrm{ft}$. 


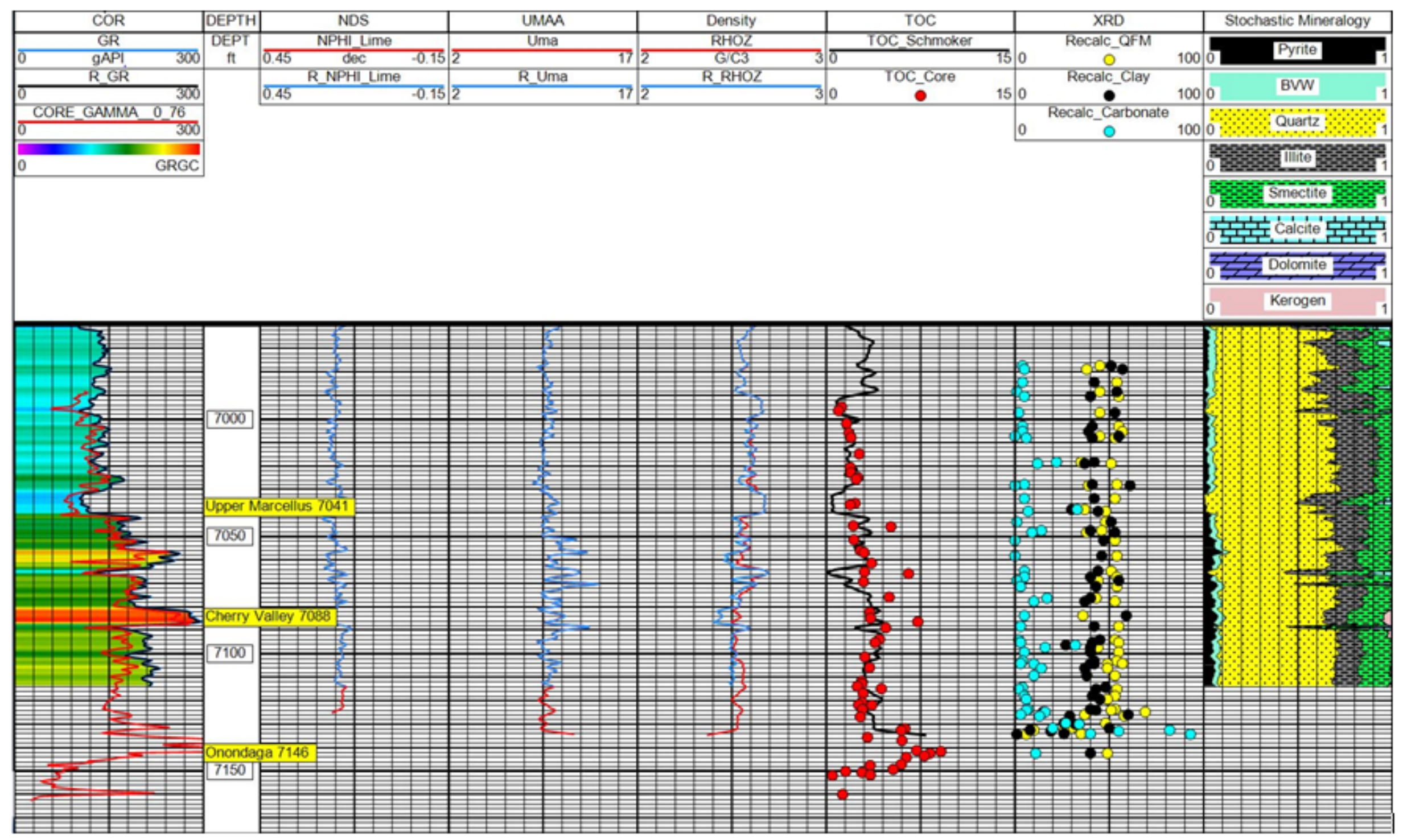

Figure 5.18. Stochastic Mineralogical model generated in the Statmin module in PowerLog by Shuvajit Bhattacharya. A statistical multi-mineral solution was obtained using 4 different well logs: core GR, corrected neutron porosity, corrected bulk density, and the Umaa log. The output solution (Track 7) is comprised of 8 log curves: quartz, smectite, illite, calcite, dolomite, kerogen, pyrite, and bulk volume of water. 


\subsubsection{Organic Matter Evaluation}

Total organic carbon (TOC) was confirmed by evaluating the correlation between core and log derived TOC. Core derived TOC was determined using the Source Rock Analyzer at National Energy Technology Laboratory (NETL) and Core Labs RockEval pyrolysis technique. TOC in the Marcellus Formation varies significantly depending on location within the basin (5-20 wt. \%) (Matt Boyce, 2010). The range of TOC for the Marcellus in the Coldstream \#1MH well was lower than what was predicted by Boyce (2010). TOC average in the lower Marcellus ranges from $2.5 \%$ to $9.1 \mathrm{wt} . \%$, with an average TOC of 4.7 wt. \%. The upper Marcellus has slightly less organic matter, TOC ranges from $2.2 \%$ to 7.3 wt. \%, while the TOC average is 3.8 wt. \% (Fig. 5.15). For TOC weight percent of each sample, please see appendix A.

Core derived TOC is compared to log derived TOC using TOC Schmoker $($ TOC $=$ ((154.497/Bulk Density) - 57.261) (Schmoker, 1994). The bulk density (RHOB) and photoelectric (PE) are affected by the high barite mud used during drilling, and thus, correction of RHOB is necessary to calculate TOC Schmoker. The density correction provided by Schlumberger is applied to the RHOB, and subsequently, used to calculate TOC. It was observed that there was good correlation between core derived TOC and $\log$ derived TOC (Fig 5.18, Track 5). The corrected density log derived TOC matches better with the core derived TOC compared to the original RHOB log calculated TOC. The only complication with TOC Schmoker is that the digital well logs only go down to log depth of $7134 \mathrm{ft}$.

(core depth of $7147.50 \mathrm{ft}$.), and therefore, excludes the bottom of the lower Marcellus, where GR and TOC is the greatest.

Core Labs conducted vitrinite reflectance (Ro) data at 5 sample locations. Mean average Ro ranged from $2.59 \%$ to $2.89 \%$, suggesting the organic matter is post-mature and in the dry gas zone of hydrocarbon generation. Figure 5.19 is a graph of production index, which shows the transformation 
ratio of kerogen into free hydrocarbons, plotted against thermal maturity based on Ro percent. The graph further proves that the 5 sample locations fall within the dry gas zone. Figure 5.20 plots hydrogen potential against TOC weight percent, which displays TOC data points in the dry gas zone consistent with type IV kerogen.

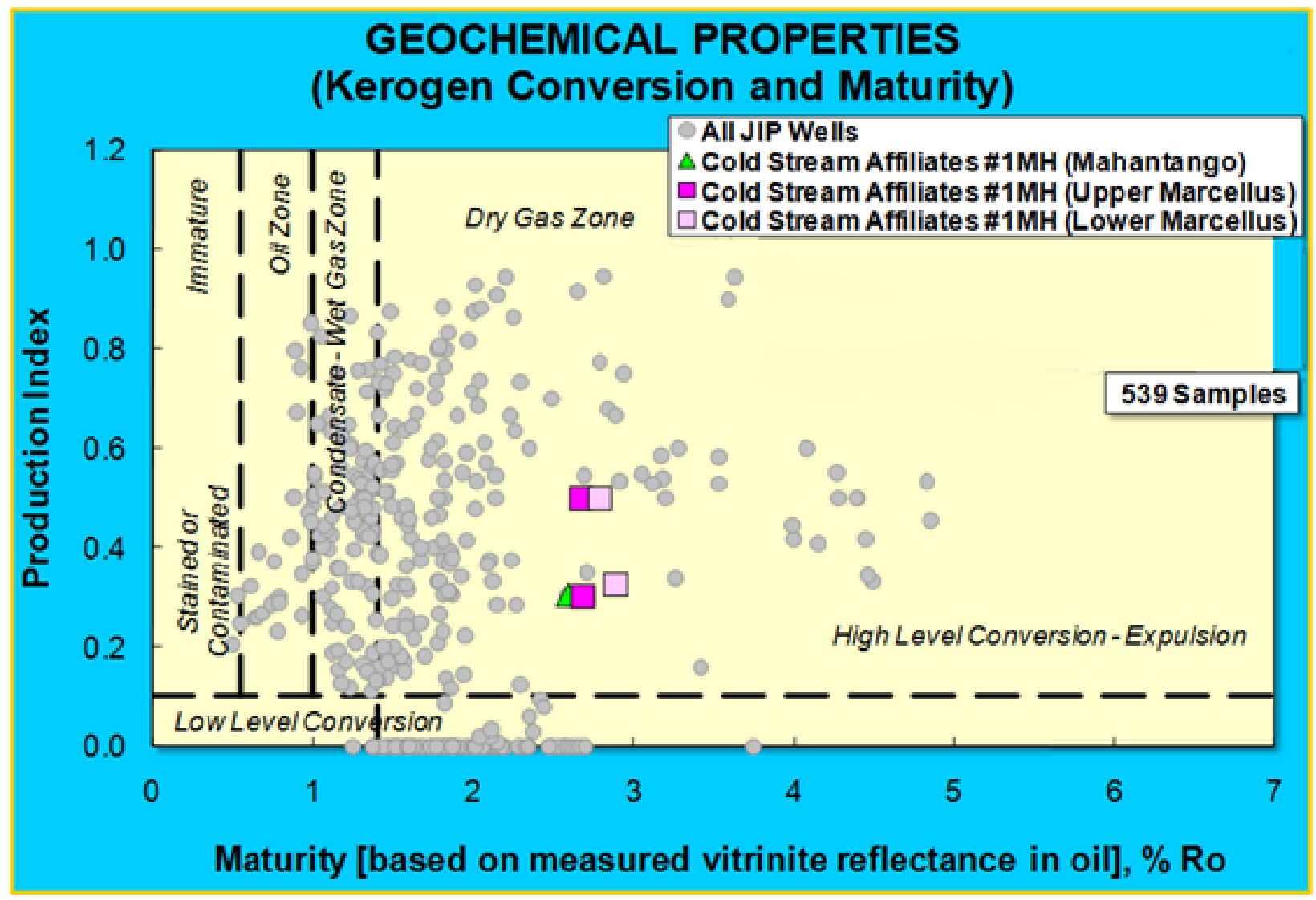

Figure 5.19. Production index verse vitrinite reflectance data graph illustrates that the 5 Ro samples fall within the dry gas zone, which is indicative of thermally post-mature rocks. 


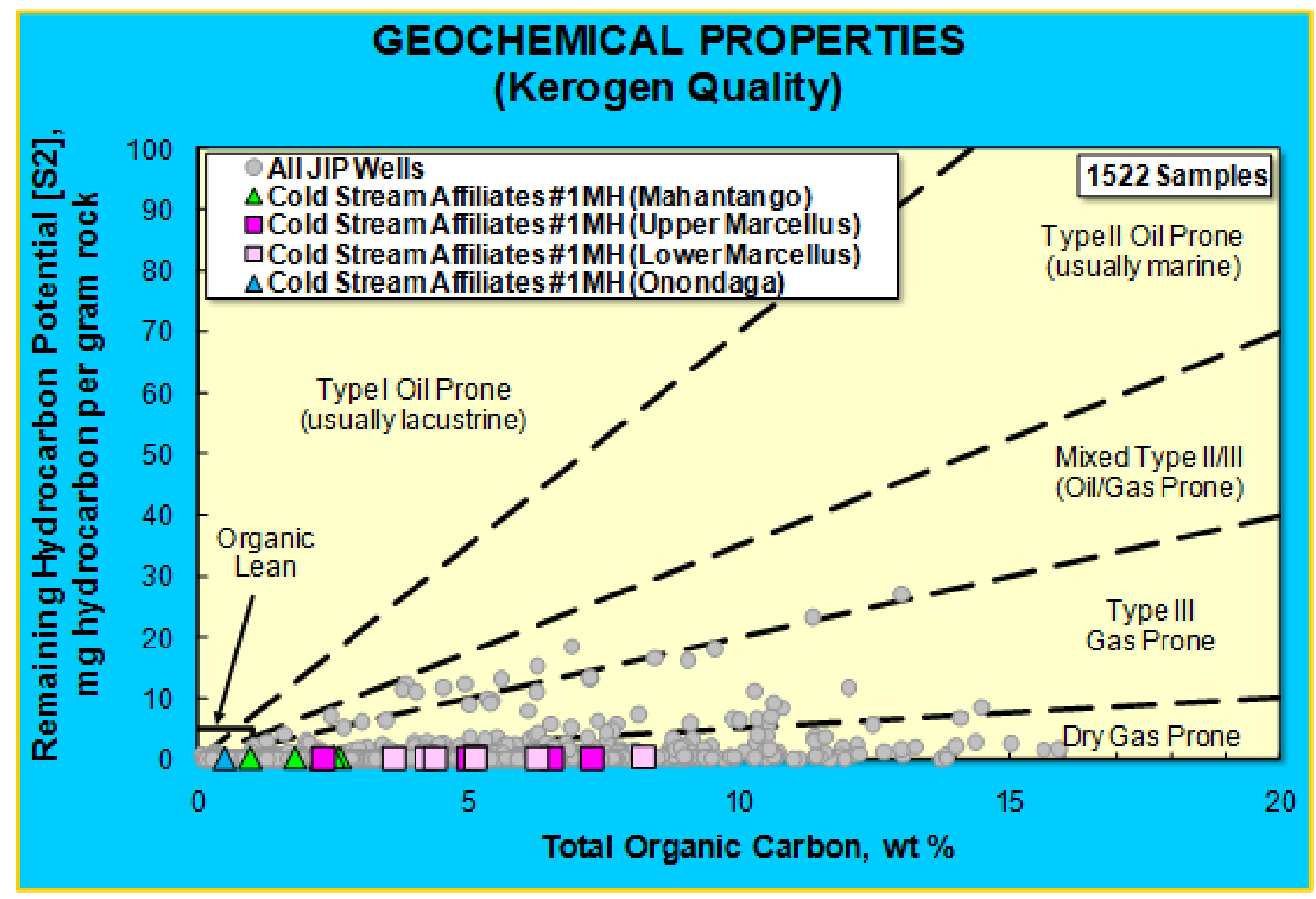

Figure 5.20. Hydrogen potential verse TOC weight percent graph shows a low hydrogen index, which is dry gas prone and indicative of type IV kerogen.

\subsubsection{Spectral Core Gamma Ray Log Analysis}

The spectral gamma ray (GR) taken from the core was used during logging to help confirm sequence boundaries, stacking patterns, and changes in grain size. The spectral GR response is divided into individual measurements of potassium (K), thorium (Th), and uranium (U), which reflect the natural radioactivity of the cored interval. The proportions of $\mathrm{K}$, $\mathrm{U}$, and Th provide important information regarding diagenesis and deposition, by evaluating clay type and redox potential. Uranium is associated with phosphates, high organic matter, and slow sedimentation, which is related to low energy system and anoxic water conditions. Thorium is associated with heavy minerals and volcanic ash, while potassium is associated with clay minerals and potassium feldspars. Together, Th and K rich deposits 
are suggestive of more rapid sedimentation, terrestrial input and higher kinetic energy (Lazar et al., 2010, Abouelresh and Slatt, 2011).

The spectral core GR curve was plotted beside $\mathrm{Th} / \mathrm{K}$ and $\mathrm{Th} / \mathrm{U}$ ratio curves, individual curves of potassium, thorium, and uranium, as well as log and core derived TOC (Fig. 5.21 and 5.22). The Th/K ratio curve helped to evaluate clay type in relation to stratigraphy, with values less than 3.5 signifying illite-rich rock and greater than 3.5 signified smectite-rich strata. Illite is associated with higher degree of diagenesis, since at greater depths and temperatures smectite clay is converted to illite. Illite is the dominant clay type in the bottom part of the lower Marcellus (Fig. 5.21), which is consistent with expectations for higher gamma ray intervals. The clay types for the individual formations are best illustrated in the graph of thorium against potassium (Fig 5.23). This graph shows clay type that ranges from illite to smectite, with majority of the points falling in the mixed-layer smectite zone. The $\mathrm{Th} / \mathrm{U}$ curve determines redox potential, whether an oxidizing or reducing environment is present, which for the Marcellus was almost entirely reducing, except for a few oxidizing zones. Figure 5.24 plots the $\mathrm{Th} / \mathrm{K}$ against the $\mathrm{Th} / \mathrm{U}$ values to obtain an overall image of clay type in relation to reducing/oxidizing environment for the Marcellus, Onondaga, and Mahantango Formations. Also noteworthy is the uranium curve (Fig. 5.21 and 5.22, Track 6), which shows good correlation to log and core derived TOC. 


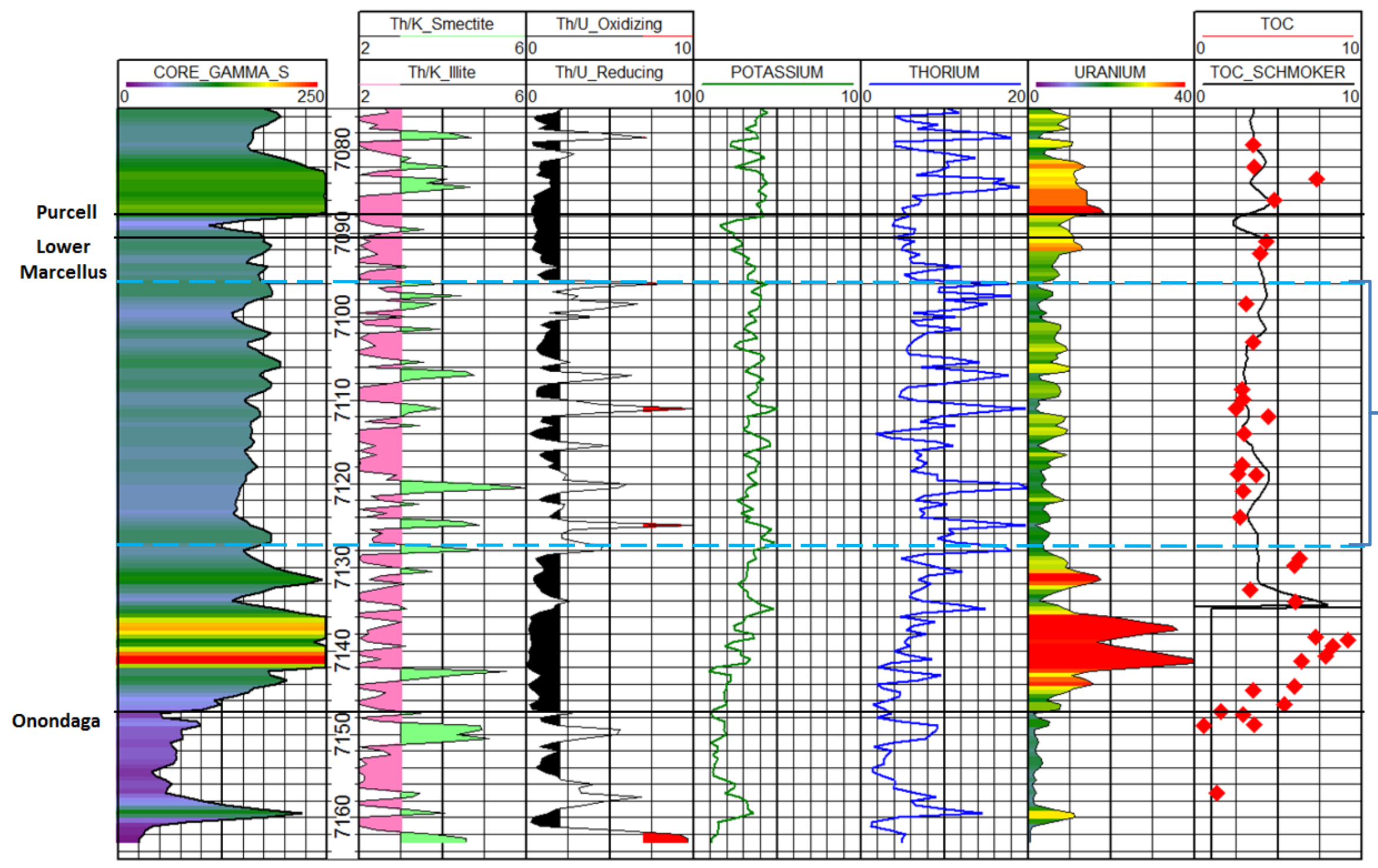

Zone of

greater terrigenous influxand oxidizing œnditions

Figure 5.21. Spectral core GR of the Onondaga, lower Marcellus, Purcell Limestone, and the bottom part of the upper Marcellus compared to Th/K curves, Th/U curves, individual curves of $\mathrm{K}$, Th, and $\mathrm{U}$, as well as log and core derived TOC for comparison to the U curve. 


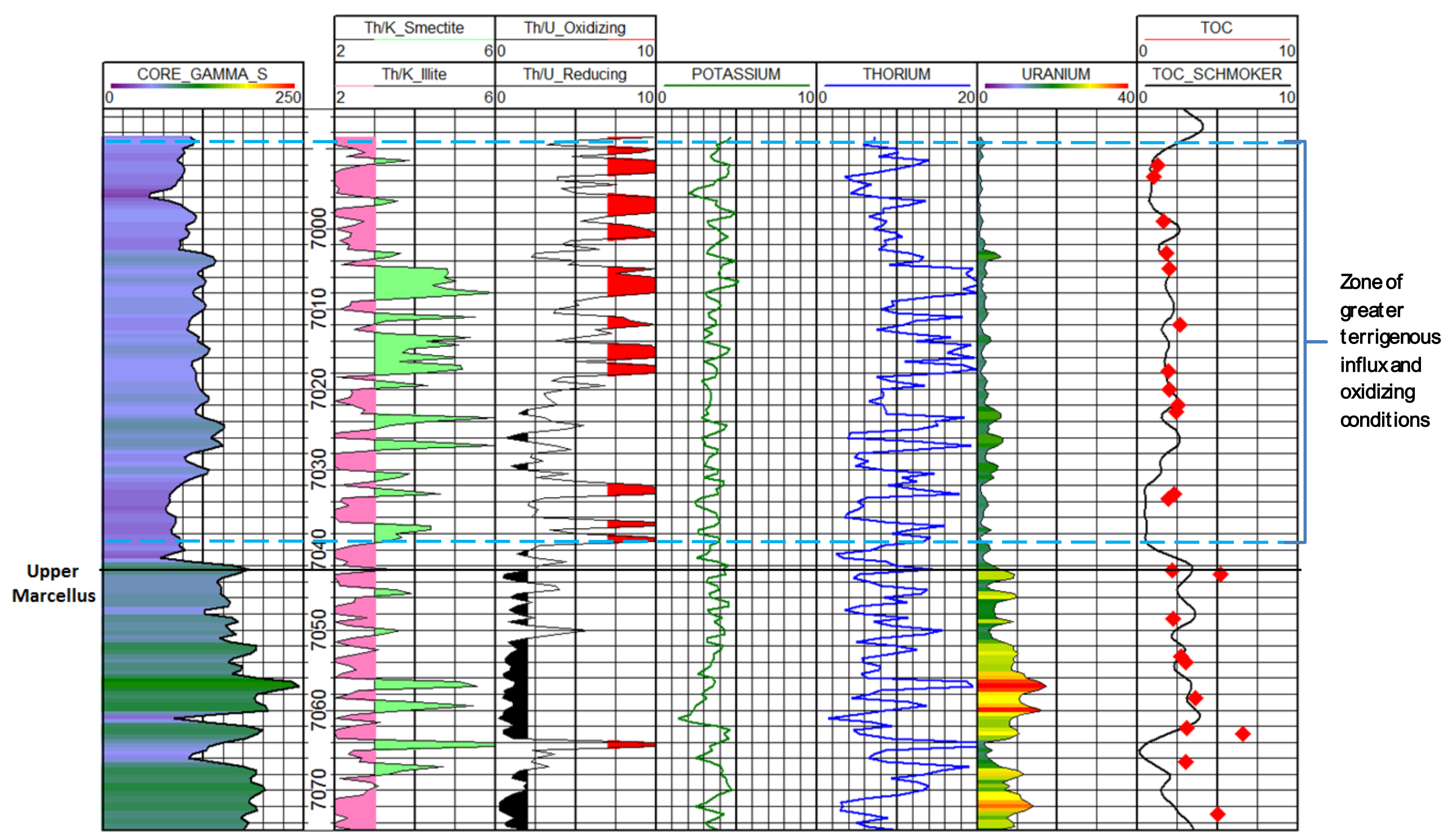

Figure 5.22. Spectral core GR log of the upper Marcellus and lower part of the Mahantango Formation compared to Th/K curves, $\mathrm{Th} / \mathrm{U}$ curves, individual curves of $\mathrm{K}$, Th, and $\mathrm{U}$, as well as log and core derived TOC. 


\section{Coldstream 1MH}

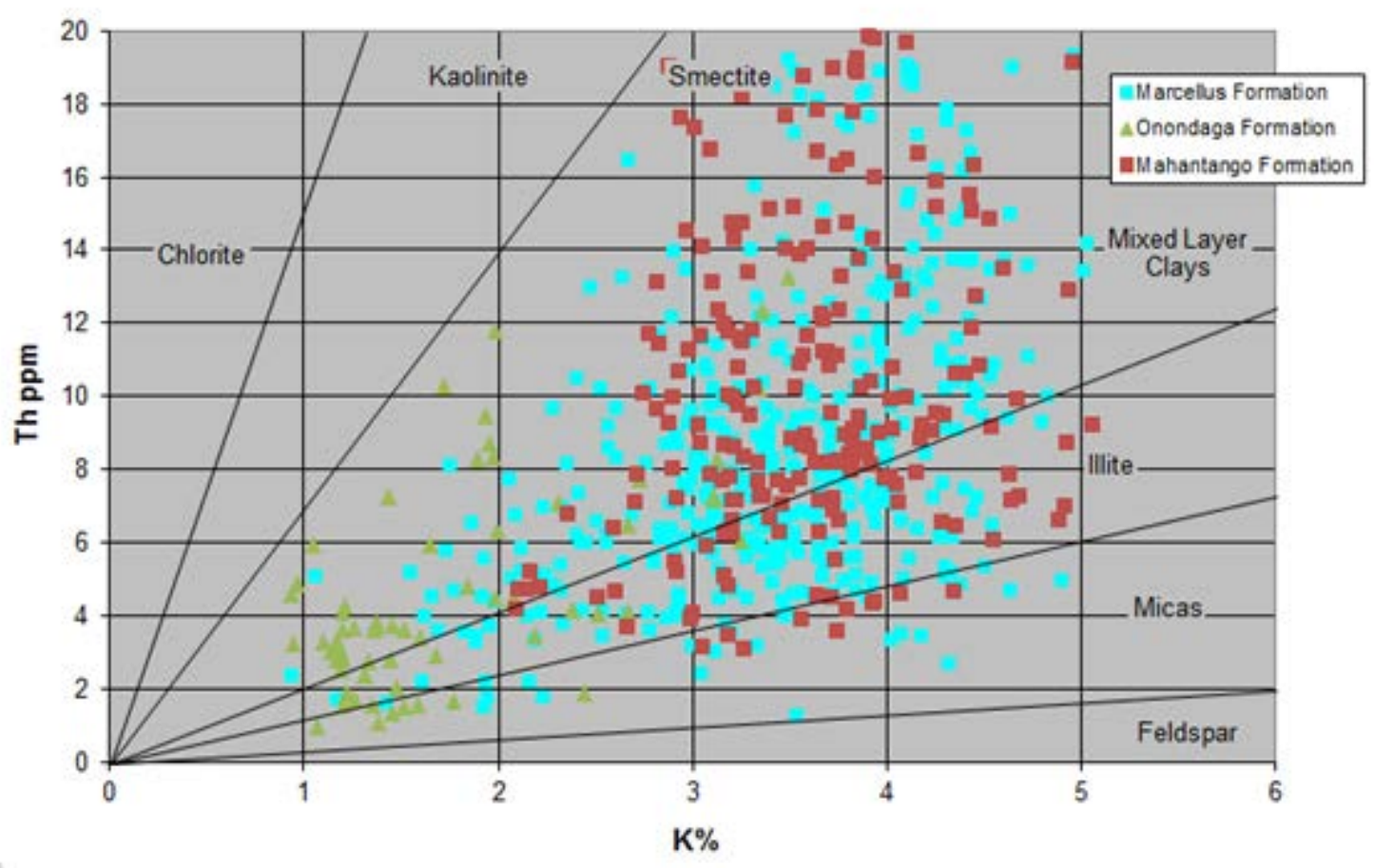

Figure 5.23. The cross-plot of $T h$ and $K$ for the cored interval shows relative clay type. For the Onondaga, Marcellus and Mahantango units the clay type ranges from illite to smectite, with a majority of the points concetrated on the reference line between mixed layer clay and illite. 


\section{COLDSTREAM 1MH}

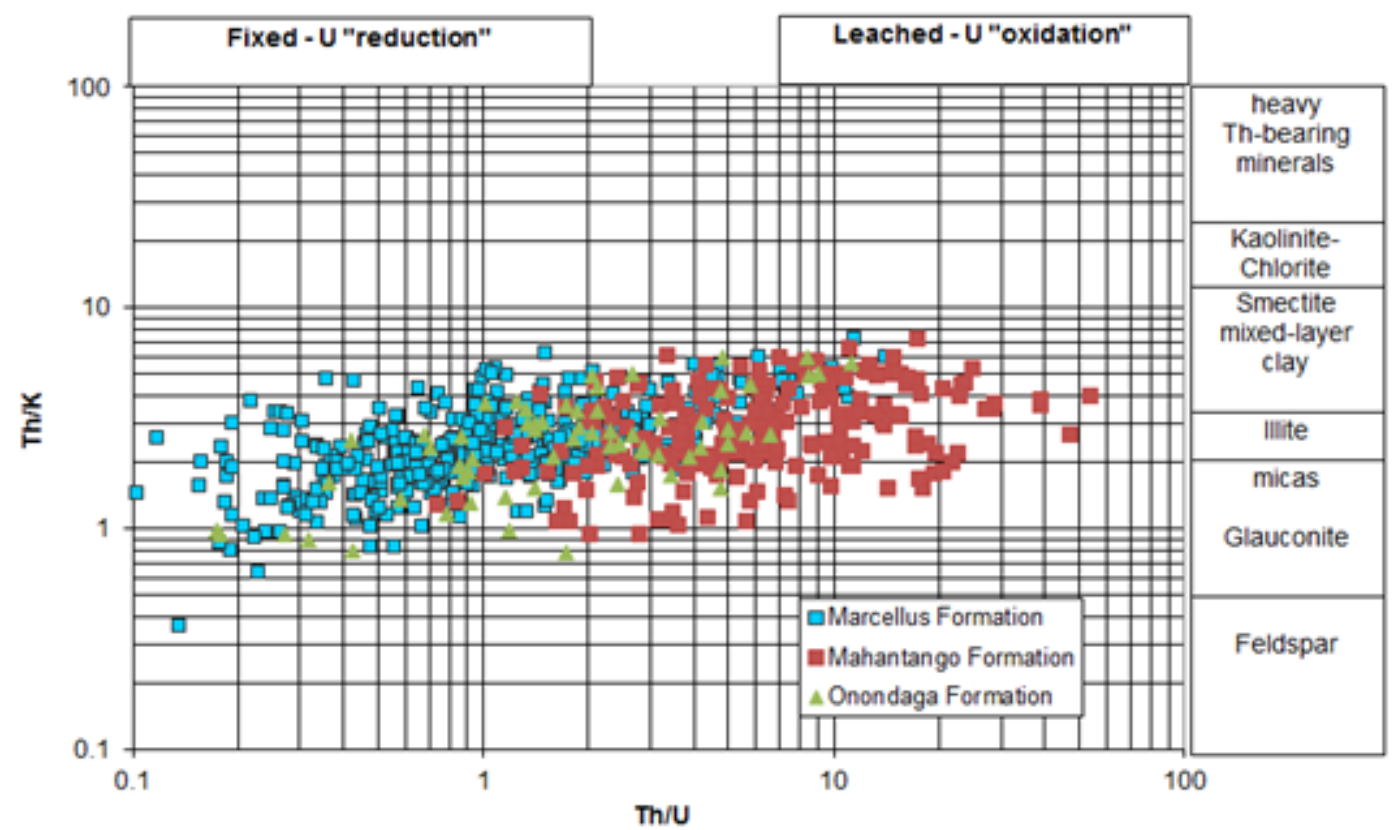

Figure 5.24. The cross-plot of $\mathrm{Th} / \mathrm{K}$ against $\mathrm{Th} / \mathrm{U}$ illustrates the clay type in relation to redox potential for the Onondaga, Marcellus, and Mahantango formations. This plot is consistent with clay type seen in Figure 5.23, with most of the data points concentrated around the illite to mixed-layer clay range. The Marcellus Formation (blue square) is a more reducing environment, which is expected of a shale deposited during anoxic water conditions. The other formations, especially the Mahantango, were depositioned in a more oxygen rich environment.

\subsubsection{Ingrain's Digital Rock Physics}

Digital rock physics (DRP) is a new core analysis method being used in the industry, specifically for unconventional reservoirs. This analysis uses a much finer resolution than wireline logs, making it possible to visualize very small vertical changes in the cored interval. Ingrain's CoreHD ${ }^{\circledR}$ Whole Core High Definition CT Scanning and Logging service highlighted different rock lithologies for qualitative facies analysis. Each boxed section of core was imaged at a resolution of 670 microns per vertical slice. Bulk density (RHOB) and photoelectric factor (PEF) was calculated from X-ray 3D images produced at different energy levels. A color-coded CoreHD ${ }^{\circledR}$ facies classification was applied to the RHOB and PEF log data based on high or low values. The CoreHD ${ }^{\circledR} \log$ data was assigned to color-coded RHOB and 
PEF cross plots of population density, facies and depth. The crossplots display mineral trend lines of pure quartz $(\mathrm{PEF}=1.8)$ and pure calcite $(\mathrm{PEF}=5.08)$. The cutoff values divided the points into semiquantitative color-coded CoreHD ${ }^{\circledR}$ facies (Fig. 5.25) based on PEF and RHOB values. Cutoff values are assigned by evaluating the population density crossplot, which indicates where the majority of the data points plot within the given core intervals.

However, the color-coded lithofacies do not directly relate to one specific rock lithology, and thus, need to be compared to other aspects of core analysis. It was important to keep in mind PEF values for different minerals (Fig. 5.26), especially since carbonate, through mineralogical evaluation, was not found to be abundant in the cored interval, and the color-coded facies are identified based on the quartz to calcite ratio. It might be more appropriate to consider the PEF value of different clay types, specifically between illite and smectite (Fig. 5.25), for interpretation of DRP lithofacies. RHOB is indicative of organic-richness, assuming more organic-rich facies will be lighter. When comparing DRP color-coded lithofacies to spectral core GR for the lower Marcellus (Fig. 5.27), it is evident that there is some correlation, specifically how the DRP color-coded pink to red facies correlates the high GR zone. Furthermore, comparison of spectral core GR to Ingrain's CoreHD ${ }^{\circledR}$ lithofacies classification was an effective way to visualize the very small scale, vertical changes within the cored interval that otherwise are almost impossible to determine. DRP is used to supplement the core-scale lithofacies analysis, as well as for showing small-scale fluctuations assumed to be associated with variation in anoxia in the sequence stratigraphic framework model (appendix B). 

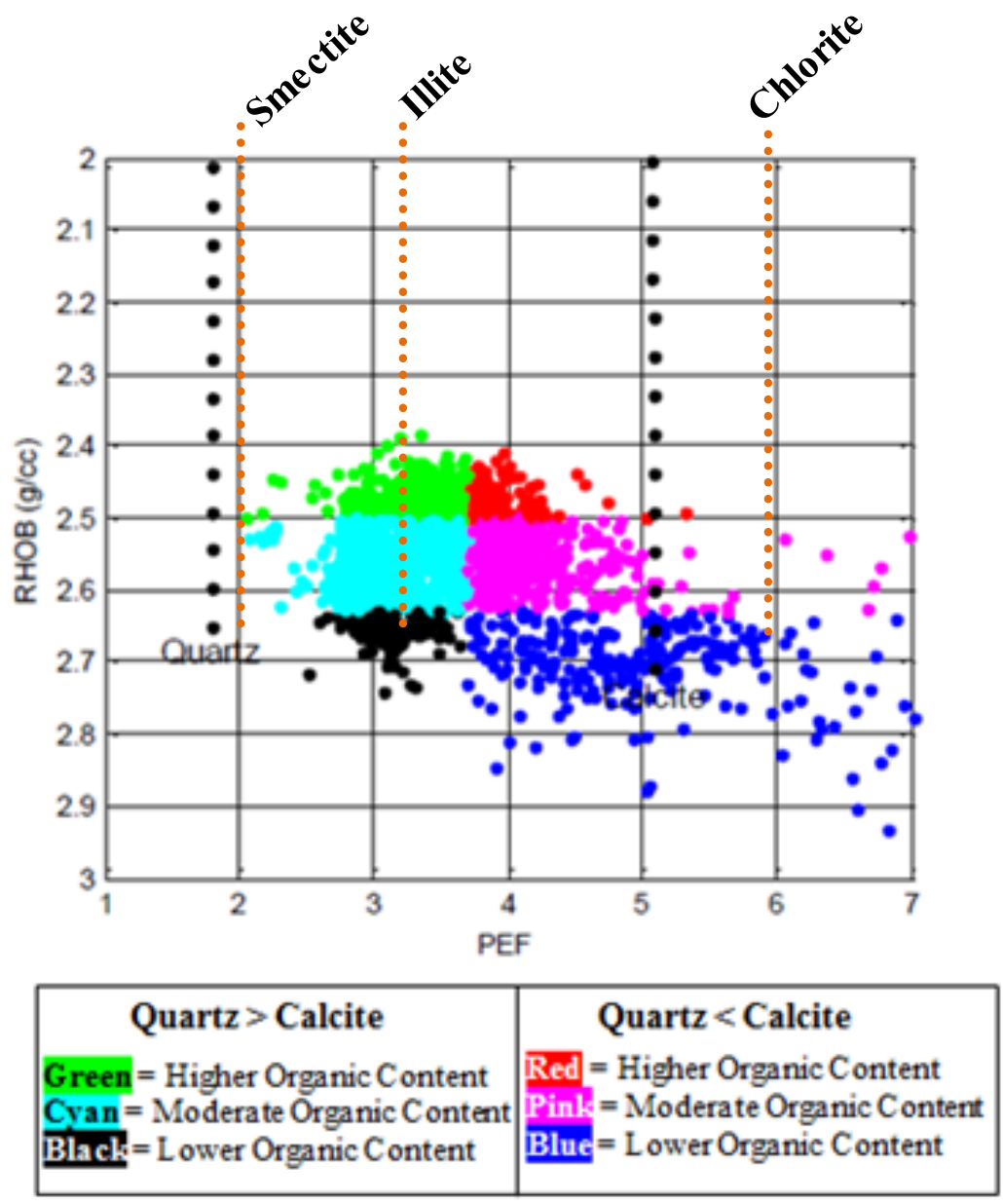

Figure 5.25. This color-coded facies crossplot shows the cutoff values for Ingrain's CoreHD ${ }^{\circledR}$ facies classification for the whole Coldstream \#1MH core. The colors correspond to different color-coded facies that are selected based on PEF and RHOB values. The two black reference lines correspond to pure minerals of quartz and calcite, while the orange lines correspond to pure minerals of smectite and illite. Facies organic content is related to RHOB values, given that higher organic content will have a lower bulk density.

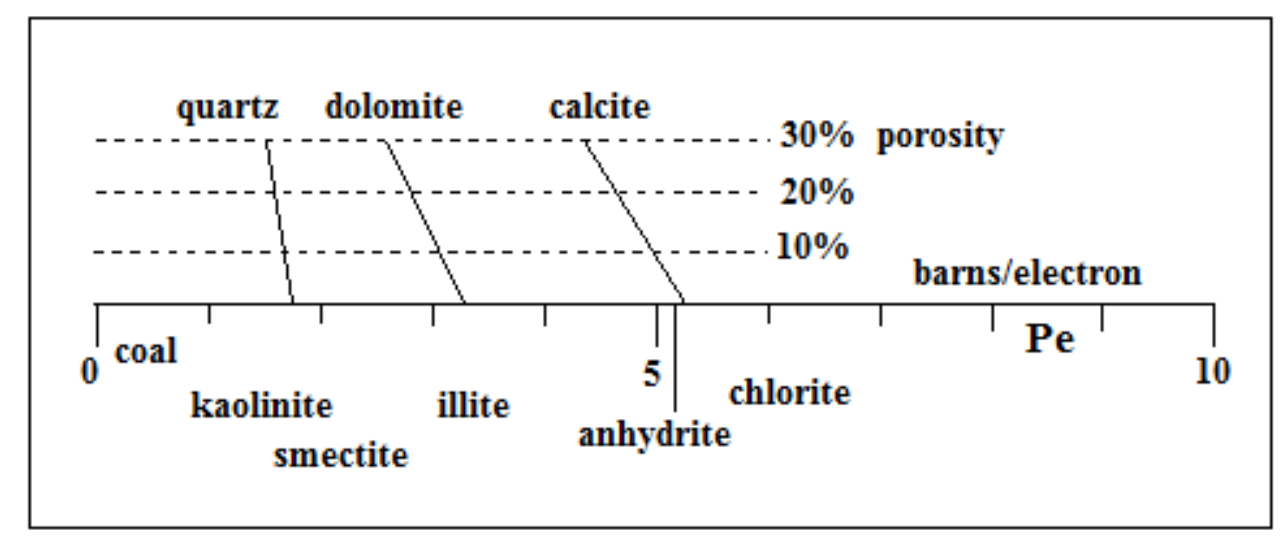

Figure 5.26. PE values for different minerals. Knowledge of PE values for different minerals is important for the interpretation of Ingrain's Core HD Facies. 


\title{
Lower Marcellus
}

\author{
Core Depth: 7,140.00' - 7,160.00' \\ Log Depth: 7126.50' - 7146.50'
}

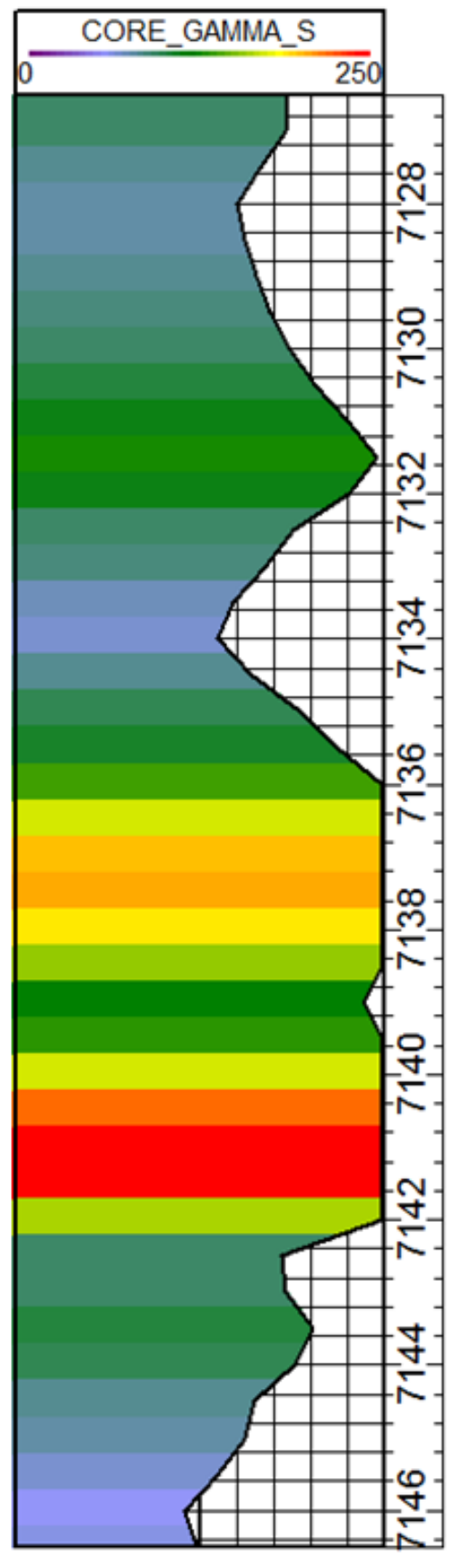

\section{DRP FACIES LOG}

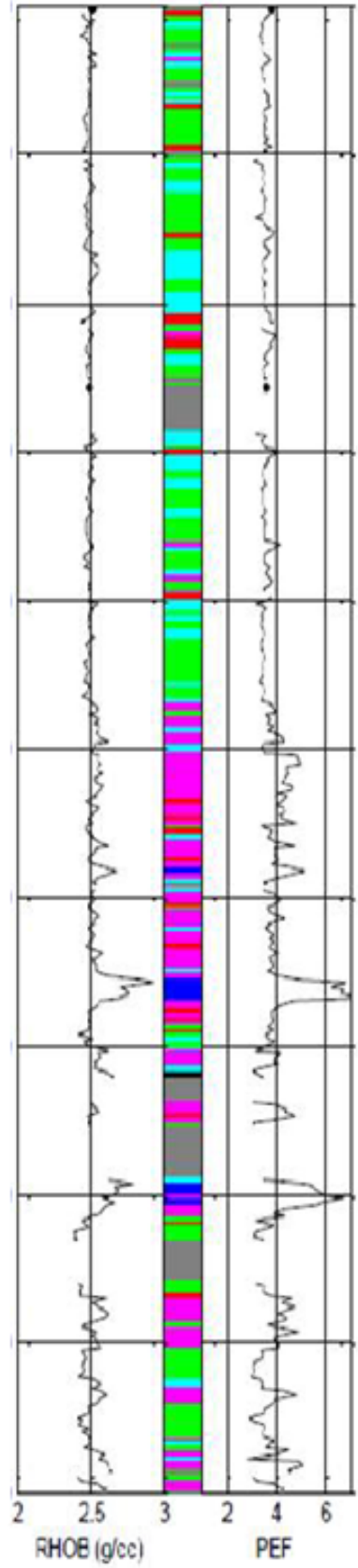

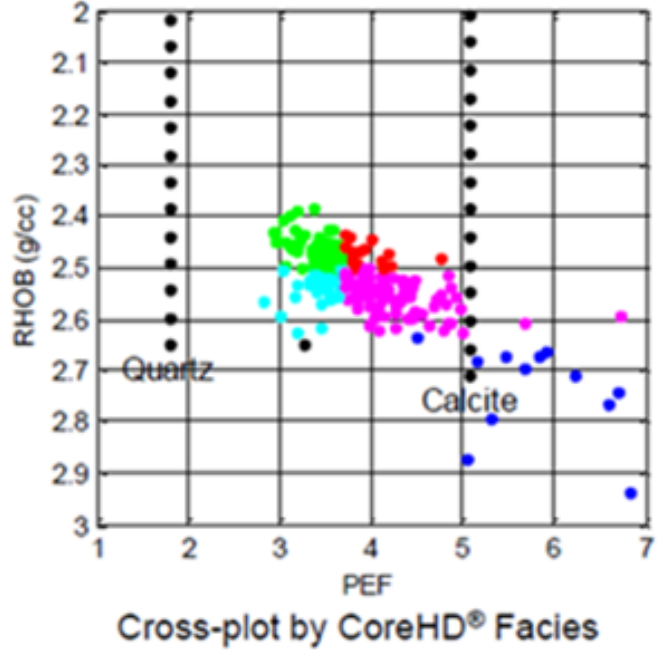

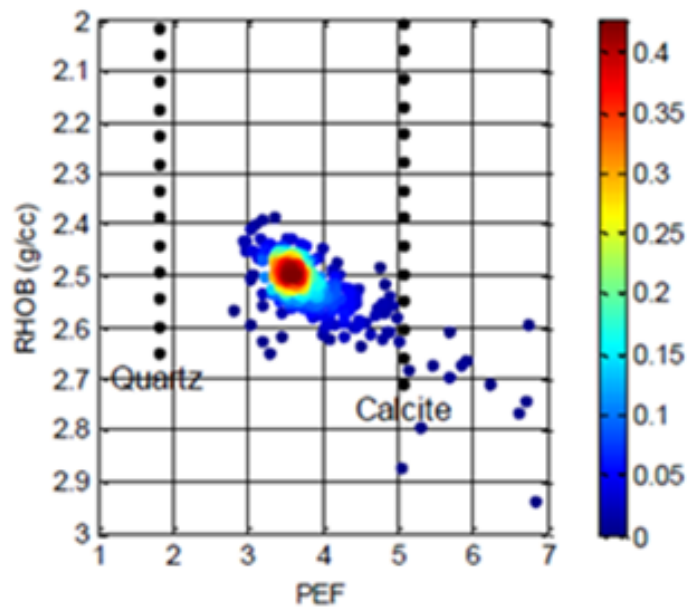

Cross-plot by Population Density

Figure 5.27. Core gamma-ray (GR) (left), CoreHD ${ }^{\circledR}$ facies log (middle), and CoreHD ${ }^{\circledR}$ facies (topright) and population density (bottom-right) crossplots for the lower Marcellus interval. For the section of high core GR (7,150 to $7155 \mathrm{ft}$.), the pink color-coded facies dominates with the blue facies being associated with calcareous pyritic concretions. The gray color is associated with missing core. 


\section{Lithofacies Analysis}

The analysis of lithofacies consists of facies descriptions and interpretation of depositional environment. Integration of core data from the Coldstream Affiliates well identified the following seven lithofacies: (1) organic-rich, siliceous shale, (2) organic-rich mudstone, (3) gray siliceous shale, (4) gray mudstone (5) calcareous shale, (6) limestone, and (7) calcareous concretion horizons. Core data, specifically XRD, TOC, and visual descriptions, helped to categorize lithofacies, one through six, by using a similar method outlined in Figure 4.1, but with parameters that incorporate the data for the cored interval. Figure 6.1 displays the criteria and parameters used to determine core scale lithofacies based on XRD and TOC, but visual descriptions were also taken into consideration during lithofacies classification. Carbonate weight percent in this well is relatively low, as seen in the mineralogical model, and only 11 of the 59 samples had a carbonate percent greater than or equal to 20 wt. \%. All XRD and TOC data was assigned an individual lithofacies, one through six, which were then averaged together. The results for XRD, TOC, and associated lithofacies are located in appendix A. 


\section{Core Data}

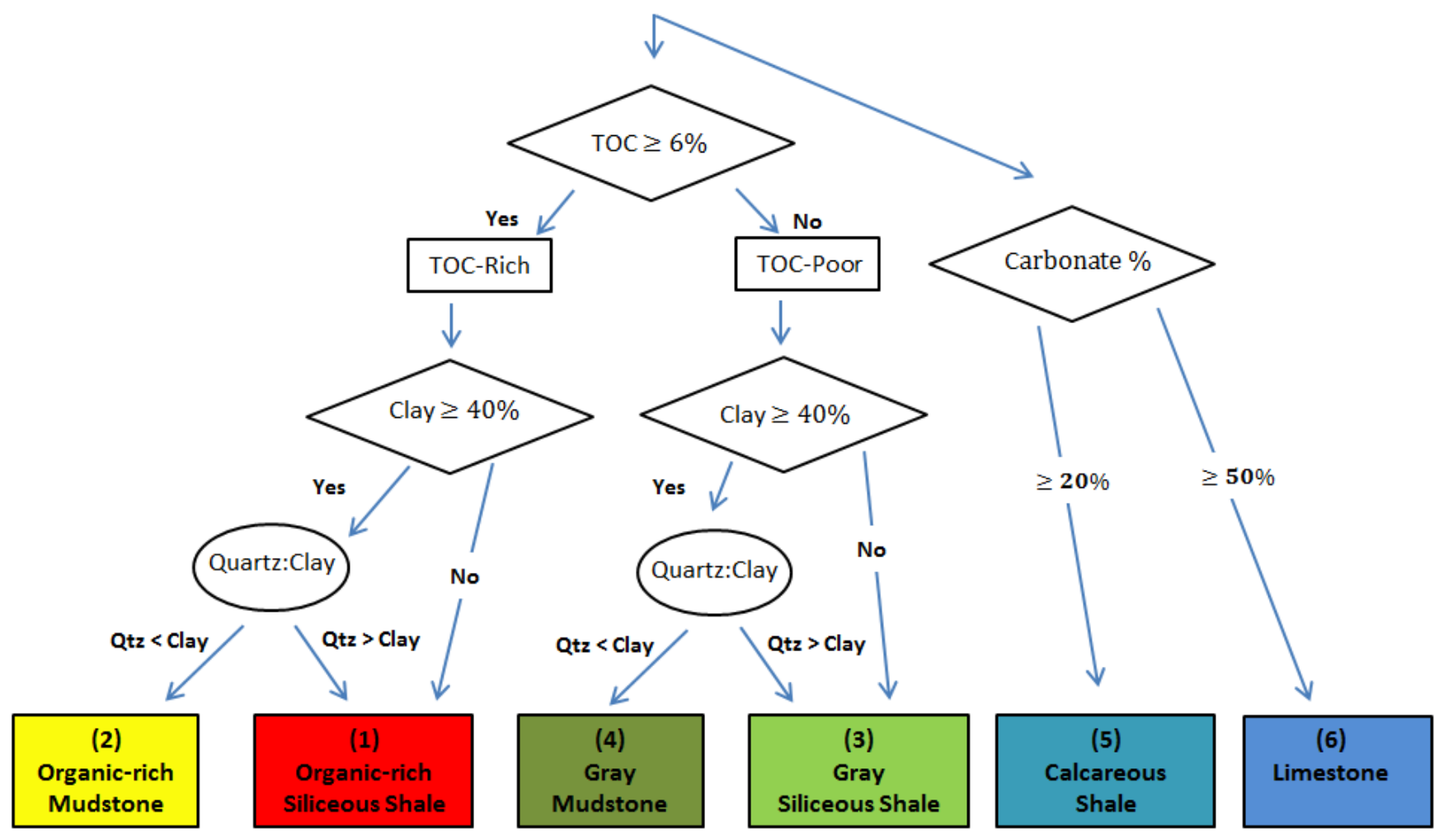

Figure 6.1. Criteria for lithofacies prediction for the Coldstream core. Core data included XRD, TOC, spectral core GR and visual descriptions.

\subsection{Lithofacies Descriptions}

Lithofacies, one through seven, are described in the following sections, along with averaged XRD, TOC, and GR response, thin-section and core images, as well as total thickness for each lithofacies. K-bentonite ash beds were sampled and analyzed by Parrish (2013), which was discussed in section 2.3. The lithofacies were determined based on qualitative and quantitative criteria that were mentioned previously in chapter 5. The lithofacies were then extrapolated to a core-scale lithofacies log in Petra ${ }^{\circledR}$ and compared to spectral core GR, DRP lithofacies, lithology, sedimentary and structural features, and the $\mathrm{Th} / \mathrm{K}$ ratio curve (see appendix B, Fig. 1-4). These figures act as a visual model for the sequence stratigraphic framework of the cored well. 
Ingrain's DPR ColorHD ${ }^{\circledR}$ lithofacies classification showed a multitude of variation in the cored interval on a very fine scale. However, despite the variation, the DRP color-coded facies showed some correlation to the lithofacies log and spectral core GR. DRP lithofacies are selected based on bulk density and photoelectric values from the CT scan, and thus, the color-coded facies do not directly correspond to the core-scale lithofacies described below. The DRP classification did exhibit colorcoded facies that could be typed to one or more of the core-scale lithofacies, but overall the DRP analysis showed better correlation to sequence stratigraphic intervals than to specific core-scale lithofacies.

\subsubsection{Facies 1-Organic-rich Siliceous Shale}

Lithofacies 1was identified as a grayish black, organic-rich, siliceous shale, which was found in the basal section of the lower Marcellus, where GR values are highest (see appendix B, Fig. 3). Total thickness for this facies was approximately $6.5 \mathrm{ft} .(2 \mathrm{~m})$ out of the $173.65 \mathrm{ft} .(53 \mathrm{~m})$ of the cored interval and number of samples in this facies is 6 . Overall the laminations were faint, and discontinuous, with a thin-section image showing a thin silty lamination. Thin-section images also showed abundant silt-sized particles and framboidal pyrites. Silica content is also in the form of polycrystalline quartz, which was interpreted as algae cysts (Fig. 5.10, LM-2). In the core description, abundant pyrite nodules, along with discontinuous calcite lenses were noted, as well as many mineralized fractures filled with calcite and a few horizontal slickensided fractures. No bioturbation or fossils were evident in core or thin-section description. Data from pyrolysis indicated high organic carbon, with the average TOC at approximately 7.1\%. The XRD data was averaged for each lithofacies. The facies were identified by mineral weight

percentages within a specific range and visual descriptions (Fig. 6.2). The organic-rich, siliceous shale has on average $50.2 \%$ quartz, $7.6 \%$ carbonate, $32 \%$ clay, and $10 \%$ pyrite. 


\subsubsection{Facies 2-Organic-rich Mudstone}

Lithofacies 2 is grayish black, organic-rich mudstone, also associated with high GR values. This facies is located in the basal part of the lower Marcellus as well as in the basal part of the upper Marcellus (see appendix B, Fig. 1-3). Total thickness for this facies is slightly less than Facies 1 at 6.28 ft. $(1.9 \mathrm{~m})$, but with only 4 samples in Facies 2 . In core description, the facies appears to have low to moderate silt content, high clay content, abundant pyrite, low carbonate, and faint, discontinuous laminations. Thin-section images showed that there are abundant illite blebs, which were interpreted as compacted, horizontal, clay-filled burrows. The large silt sized grains identified in the thin-section are most likely carbonate, with some scattered calcified algal cysts, but overall carbonate is not abundant in the matrix (Fig. 5.11, UM-8). The number of calcite filled fractures is lower than in Facies 1, while continuous calcite lenses are more common. Occasional skeletal fragments were scattered in thinsection and consist of mostly brachiopod shells, with the exception of styliolinids and ostracods identified at log depth of $7065.5 \mathrm{ft}$. (core depth, $7079 \mathrm{ft}$.). Pyrite percentage is highest in this facies and occurs as replacement and as dispersed framboids. TOC, averaged at $7.0 \%$, is approximately the same as Facies 1 but the range is smaller, from $6.3-7.8 \%$. When compared to Facies 1 , the XRD data shows higher clay at $47.1 \%$ and lower quartz at $36.8 \%$, with carbonate at $3.6 \%$ and high pyrite at $12.6 \%$ (Fig. 6.2).

\subsubsection{Facies 3-Gray Siliceous Shale}

Lithofacies 3 was identified as dark-gray, siliceous shale, with low to moderate organic content. It is the most common lithofacies in the cored interval, with a total thickness of approximately $80 \mathrm{ft}$. (24 $\mathrm{m})$, containing 30 of the 59 samples. It is principally located in the middle to upper section of the lower and upper Marcellus (see appendix B, Fig. 1-4). This facies has faint to moderate laminations, and in some locations the bedding parts at a low angle. Clay content is moderate to low and carbonate is moderate to non-calcareous. The degree of calcareous content seems to be controlled by calcareous 
concretions, mineralized-filled fractures, and microfossils. However, thin-sections reveal dispersed skeletal fragments, some partly silicified, as well as silt and clay filled burrows (Fig. 5.10, LM-5). Fossils fragments consist of brachiopod shells, styliolinids, and ostracods in the top part of the lower Marcellus. As the lower Marcellus approaches the Purcell Limestone interval, the fossils become more abundant and form laminations consisting of skeletal fragments. Pyrite seen in core description was in the form of small nodules and as replacement of fossils, while in thin-section there was notable framboidal pyrite. TOC was averaged at approximately 3.0\%. XRD data for gray siliceous shale had on average $48.9 \%$ quartz, $6.6 \%$ carbonate, $38.8 \%$ clay, and $5.6 \%$ pyrite (Fig. 6.3 ).

\subsubsection{Facies 4-Gray Mudstone}

Lithofacies 4 is a dark-gray mudstone, with low to moderate organic matter and high to moderate clay content. This facies was the second most common lithofacies within the Coldstream core. The total thickness is approximately $45 \mathrm{ft}$. $(13.7 \mathrm{~m})$, while the number of samples within this facies is 6 . Facies 4 is found in the top part of the lower and upper Marcellus, in addition to the Mahantango Formation (see appendix B, Fig. 1-4). Bedding consists of faint to moderate, planar laminations, with beds parting at a low angle approaching the upper Marcellus-Mahantango contact. In thin-section, a contrast between lighter and darker laminae was noted around a log depth of $7005.5 \mathrm{ft}$. (core depth, 7019 ft.), which may indicate a transition between lower to higher organic content. Carbonate is relatively low, with degree of calcareous content associated with microfossils, small calcareous nodules, and calcite filled fractures, which are the most abundant in this facies. Scattered skeletal fragments of brachiopod shells were found in thin-section and core description. Illite blebs, assumed to be compacted clay filled burrows, are also present in thin-section (Fig. 5.12, MAH-15). Averaged TOC for the gray mudstone facies is $2.6 \%$, ranging from 1 to $5.1 \%$, which is very similar to the gray siliceous shale facies. Average XRD data differsfrom Facies 3, in that quartz was lower at $41.1 \%$ and clay was higher at $51.4 \%$, with carbonate at $2.3 \%$ and pyrite at $3.9 \%$ (Fig. 6.3). 


\subsubsection{Facies 5 -Calcareous Shale}

Lithofacies 5 was determined to be dark-gray, calcareous shale, with moderate clay and silt, and moderate to low organic content. The calcareous shale is located mainly in the Onondaga Formation and around the Onondaga/lower Marcellus contact (see appendix B, Fig. 1-3). It is associated with the Purcell Limestone interval and the small limestone interval around $7066.5 \mathrm{ft} . \log$ depth (core depth, $7080 \mathrm{ft}$.). Facies 5 makes up approximately $14 \mathrm{ft} .(4 \mathrm{~m})$ of the cored interval and consists of 8 samples. Strong wavy laminations were present around the lower Marcellus and Onondaga contact. Bioturbation is common, with both horizontal and vertical burrows. Fossil skeletal fragments are abundant, with occasional body fossils that include moldic brachiopods, microfossils, styliolinids, and crinoids (Fig. 5.11, UM-11). Framboidal pyrite, pyrite nodules, and bands are present throughout the interval. The average TOC is $3.5 \%$ for the 8 representative samples. XRD data established average mineral percentages of carbonate (29.8\%), quartz (35\%), clay (35\%), and pyrite (3.3\%) (Fig. 6.4).

\subsubsection{Facies 6-Limestone}

Lithofacies 6 is the most common in the Onondaga Formation $\left(7160.65^{\prime}-7172.60^{\prime}\right)$, although not continuous, as it is interbedded with calcareous shale. It also occurs at the Onondaga-Lower Marcellus contact (7155.70'-7160.65'), where beds become thinner and interbedded calcareous shale units are more dominant. There are a few more thin beds of this lithofacies throughout the cored well. For example, the Purcell Limestone, while only $3 \mathrm{ft} .(0.9 \mathrm{~m})$ thick is partly made up of an allochemical, argillaceous limestone. In general, this lithofacies is medium to dark-gray, packstone to wackestone, to argillaceous limestone, sometimes micritic in nature. It is often massively bedded, unless interbedded with calcareous shale, which displayed strong laminations. Facies 6 typically has abundant fossils and skeletal fragments, consisting of brachiopods, crinoids, and styliolinids. Bioturbation is strong to sparse in nature. Fracture intensity is relatively high in this facies, and thus, contains abundant mineralized fractures (Fig. 5.8 and Fig. 5.12, ON-1). XRD data for the 3 representative samples are averaged at 
$75.6 \%$ calcite, $9.4 \%$ clay, $35 \%$ quartz, and $1.3 \%$ pyrite. Average TOC was unsurprisingly low at $1.6 \%$ (Fig.6.4).

\subsubsection{Facies 7-Calcareous Concretions}

Large, often pyritic, calcareous concretion horizons were relatively common, especially in the Marcellus Formation. The carbonate concretions varied in size, ranging from approximately 3 to 8 in. $(7.6$ to $20 \mathrm{~cm}$ ) thick and often extended beyond the core diameter. These calcareous concretions are often found in close proximity with calcite filled fractures. Concretions are often rimmed with pyrite and contain pyrite bands. These concretions were dark to medium gray, consisting of mudstone in calcareous cement. Concretion horizons do not have any qualitative data and were only observed in the physical core, but can be identified in the spectral core GR log and DRP lithofacies (Fig. 5.6 and 5.9). 


\begin{tabular}{|c|c|c|c|c|c|c|c|}
\hline Lithofacies & Description & $\begin{array}{c}\text { Total } \\
\text { Thickness }\end{array}$ & $\begin{array}{c}\text { Spectral Core GR } \\
\text { (API) }\end{array}$ & $\begin{array}{c}\text { Mineralogy } \\
\text { Quartz } \square \text { Clay } \square \text { Carbonate } \\
\text { Pyrite } \mathbf{D} \text { Toc } \\
\end{array}$ & $\begin{array}{l}\text { Organic Matter } \\
\text { (wt. \%) }\end{array}$ & Thin-Section Image & $\begin{array}{l}\text { Core } \\
\text { Image }\end{array}$ \\
\hline $\begin{array}{l}\text { (1) } \\
\text { Grayish Black, } \\
\text { Organic-rich, } \\
\text { Siliceous Shale } \\
\quad 6 \text { Samples }\end{array}$ & $\begin{array}{l}\text { Grayish Black, Organic-rich, } \\
\text { Siliceous Shale, Slightly to } \\
\text { Moderately Calcareous, Faintly } \\
\text { Laminated (thin-section shows a } \\
\text { thin silty laminations), Algal Cysts } \\
\text { (Polycrystalline Quartz), Abundant } \\
\text { Silt-sized Particles and } \\
\text { Framboidal Pyrites }\end{array}$ & $\begin{array}{l}\approx 6.50 \mathrm{ft} \\
\approx 1.98 \mathrm{~m}\end{array}$ & $\begin{array}{l}\text { Average GR } \\
\quad \approx 349\end{array}$ & $-10.0 \%-7.6 \%$ & $\begin{array}{c}\text { AVG TOC: } 7.1 \\
\text { Range: } 6.0-9.1\end{array}$ & $\frac{1}{x-1}$ & \\
\hline
\end{tabular}

\begin{tabular}{|c|c|c|c|c|c|c|c|}
\hline Lithofacies & Description & $\begin{array}{c}\text { Total } \\
\text { Thickness }\end{array}$ & $\begin{array}{c}\text { Spectral Core GR } \\
\text { (API) }\end{array}$ & $\begin{array}{l}\text { Mineralogy } \\
\text { Quartz } \\
\text { Pyrite clay } \mathbf{D} \text { Toc }\end{array}$ & $\begin{array}{l}\text { Organic Matter } \\
\text { (wt. \%) }\end{array}$ & Thin-Section Image & $\begin{array}{l}\text { Core } \\
\text { Image }\end{array}$ \\
\hline $\begin{array}{l}\text { (2) } \\
\text { Grayish Black, } \\
\text { Organic-rich } \\
\text { Mudstone } \\
\quad \\
\quad 4 \text { samples }\end{array}$ & \begin{tabular}{|c|} 
Grayish Black, Organic-rich, \\
Mudstone, Slightly Calcareous, Most \\
Silt Size Grains are Carbonate with \\
some Scattered Calcified Algal \\
Cysts, llite blebs Interpreted as \\
Compacted Clay- Filled Burrows, \\
High Clay Content -lllite and Chlorite \\
Dominant, Pyrite is Very Abundant
\end{tabular} & $\begin{array}{l}\approx 6.28 \mathrm{ft} . \\
\approx 1.91 \mathrm{~m}\end{array}$ & $\begin{array}{l}\text { Average GR } \\
\quad \approx 238\end{array}$ & $7.1 \%$ & $\begin{array}{l}\text { AVG TOC: } 7.0 \\
\text { Range: } 6.3-7.8\end{array}$ & & \\
\hline
\end{tabular}

Figure 6.2. Lithofacies descriptions for organic-rich siliceous shale (top) and organic-rich mudstone (bottom). 


\begin{tabular}{|c|c|c|c|c|c|c|c|}
\hline Lithofacies & Description & $\begin{array}{c}\text { Total } \\
\text { Thickness }\end{array}$ & $\begin{array}{c}\text { Spectral Core GR } \\
\text { (API) }\end{array}$ & $\begin{array}{c}\text { Mineralogy } \\
\text { Quartz } \square \text { Clay } \square \text { Carbonate } \\
\text { Pyrite }\end{array}$ & $\begin{array}{l}\text { Organic Matter } \\
\text { (wt. \%) }\end{array}$ & Thin-Section Image & $\begin{array}{l}\text { Core } \\
\text { Image }\end{array}$ \\
\hline $\begin{array}{l}\text { (3) } \\
\text { Gray Siliceous } \\
\text { Shale } \\
\text { 30 Samples }\end{array}$ & \begin{tabular}{|} 
Dark Gray, Siliceous Shale, Low to \\
Moderate Organic Content, Low to \\
Moderate Clay and Calcareousness, \\
Faint to Moderate Planar, Sitty \\
Laminations, with some Low-angle \\
Partings, Dispersed Skeletal \\
Fragments and Body Fossils, Silt \\
and Clay Filled Burrows, Pyrite is \\
Moderate
\end{tabular} & $\begin{array}{l}\approx 79.81 \mathrm{ft} \\
\approx 24.33 \mathrm{~m}\end{array}$ & $\begin{array}{l}\text { Average GR } \\
\quad \approx 148\end{array}$ & $=5.6 \%$ & $\begin{array}{l}\text { AVG TOC: } 3.0 \\
\text { Range: } 1.3-5.1\end{array}$ & 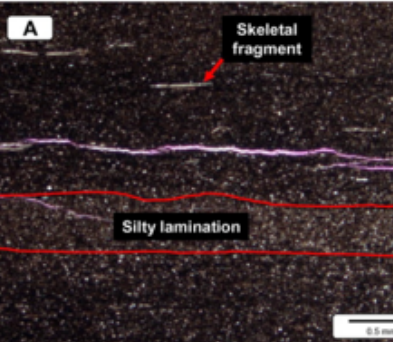 & \\
\hline
\end{tabular}

\begin{tabular}{|c|c|c|c|c|c|c|c|}
\hline Lithofacies & Description & $\begin{array}{c}\text { Total } \\
\text { Thickness }\end{array}$ & $\begin{array}{c}\text { Spectral Core GR } \\
\text { (API) }\end{array}$ & $\begin{array}{l}\text { Mineralogy } \\
\text { Quartz } 1 \text { Clay Carbonate } \\
\text { Pyite Toc }\end{array}$ & $\begin{array}{c}\text { Organic Matter } \\
\text { (wt. \%) }\end{array}$ & Thin-Section Image & $\begin{array}{l}\text { Core } \\
\text { Image }\end{array}$ \\
\hline $\begin{array}{l}\text { (4) } \\
\text { Gray Mudstone } \\
8 \text { Samples }\end{array}$ & $\begin{array}{l}\text { Dark Gray Mudstone, Low to } \\
\text { Moderate Organic Matter, Moderate } \\
\text { to High Clay, Calcareousness } \\
\text { Associated with Concretions, } \\
\text { Microfossils, Calcite Filled } \\
\text { Fractures, Scattered Skeletal } \\
\text { Fragments and Body Fossils, llite } \\
\text { Blebs, Faint to Moderate Planar } \\
\text { Laminations, Pyrite is Low to } \\
\text { Moderate }\end{array}$ & $\begin{array}{l}\approx 44.76 \mathrm{ft} . \\
\approx 24.33 \mathrm{~m}\end{array}$ & $\begin{array}{l}\text { Average GR } \\
\quad \approx 153\end{array}$ & $\begin{array}{l}2.6 \% \\
41.1 \%\end{array}$ & $\begin{array}{l}\text { AVG TOC: } 2.6 \\
\text { Range: } 1.0-5.1\end{array}$ & $\begin{array}{l}\text { Compacted } \\
\text { intueflited } \\
\text { burrows }\end{array}$ & \\
\hline
\end{tabular}

Figure 6.3. Lithofacies descriptions for gray siliceous shale (top) and gray mudstone (bottom). 


\begin{tabular}{|c|c|c|c|c|c|c|c|}
\hline Lithofacies & Description & $\begin{array}{c}\text { Total } \\
\text { Thickness }\end{array}$ & $\begin{array}{c}\text { Spectral Core GR } \\
\text { (API) }\end{array}$ & $\begin{array}{l}\text { Mineralogy } \\
\text { Quartz } \square \text { Clay } \square \text { Carbonate } \\
\text { Pyrite }\end{array}$ & $\begin{array}{l}\text { Organic Matter } \\
\text { (wt. \%) }\end{array}$ & Thin-Section Image & $\begin{array}{l}\text { Core } \\
\text { Image }\end{array}$ \\
\hline $\begin{array}{l}\text { (5) } \\
\text { Calcareous } \\
\text { Shale } \\
\quad 8 \text { Samples }\end{array}$ & $\begin{array}{l}\text { Dark to Medium Gray Calcareous } \\
\text { Shale, Moderate Clay and Silt, } \\
\text { Moderate to Low Organic Matter, } \\
\text { Strong Wavy Laminations, } \\
\text { Bioturbation is Common, Fossil } \\
\text { Bodies and Skeletal Fragments of } \\
\text { Brachiopods, Microfossils, } \\
\text { Styliolinids, and Crinoids, Pyrite is } \\
\text { Low to Moderate }\end{array}$ & $\begin{array}{l}\approx 13.92 \mathrm{ft} \\
\approx 4.24 \mathrm{~m}\end{array}$ & $\begin{array}{l}\text { Average GR } \\
\quad \approx 145\end{array}$ & $=35.0$ & $\begin{array}{l}\text { AVG TOC: } 3.5 \\
\text { Range: } 2.3-6.0\end{array}$ & $\underset{+}{+}$ & \\
\hline
\end{tabular}

\begin{tabular}{|c|c|c|c|c|c|c|c|}
\hline Lithofacies & Description & $\begin{array}{c}\text { Total } \\
\text { Thickness }\end{array}$ & $\begin{array}{c}\text { Spectral Core GR } \\
\text { (API) }\end{array}$ & $\begin{array}{c}\text { Mineralogy } \\
\text { Quartz } \square \text { Clay } \\
\text { Pyrite } \text { Corbonate }_{\text {ToC }}\end{array}$ & $\begin{array}{l}\text { Organic Matter } \\
\text { (wt. \%) }\end{array}$ & Thin-Section Image & $\begin{array}{l}\text { Core } \\
\text { Image }\end{array}$ \\
\hline $\begin{array}{l}\text { (6) } \\
\text { Limestone } \\
\text { 3 Samples }\end{array}$ & $\begin{array}{c}\text { Medium to Dark Gray, Packstone to } \\
\text { Wackestone to Argillaceous } \\
\text { Limestone, Massively Bedded, } \\
\text { Unless Interbedded with Calcareous } \\
\text { Shale, Abundant Fossils and } \\
\text { Skeletal Fragments, Strong to } \\
\text { Sparse Bioturbation, Abundant } \\
\text { Mineralized Fractures and Pyrite } \\
\text { Nodules }\end{array}$ & $\begin{array}{l}\approx 12.14 \mathrm{ft} \\
\approx 3.70 \mathrm{~m}\end{array}$ & $\begin{array}{l}\text { Average GR } \\
\quad \approx 93\end{array}$ & $=9.4 \%$ & $\begin{array}{c}\text { AVG TOC: } 1.6 \\
\text { Range: } 0.8-2.8\end{array}$ & & \\
\hline
\end{tabular}

Figure 6.4. Lithofacies descriptions for calcareous shale (top) and limestone (bottom). 


\subsection{Depositional Interpretation of Lithofacies}

Lithofacies 1 through 7 were deposited in the more proximal part of the Appalachian basin, in a shallow, restricted epicontinental sea that was below wave base. At times circulation was poor, creating a stratified water column and anoxic to euxinic bottom-water conditions. However, anoxic conditions were neither persistent nor widespread across the basin, as previously thought (Ettensohn, 1985). Instead, anoxic conditions were more localized and may have followed a retrogradational trend from west to east across the basin. In the eastern part of the basin, a shelf-like topographic high with localized structural lows was recognized based on thickness trends in the Onondaga Formation (Fig. 3.3) (Boyce, 2010, and Yanni, 2010), and is believed to influence depositional patterns. Variations in primary production, dilution, settling rates, water chemistry, paleogeography, and seasons resulted in the deposition of different lithofacies. Location of sealevel in relation to shoreline also affected the deposition of lithofacies, especially at sequence boundaries, but more recently it has been suggested that localized, micro-anoxic environments could be the result of smaller scale changes in lithofacies (Boyce, 2010).

Organic-rich, siliceous shale (Facies 1) is interpreted to be a condensed section that coincided with a relative deepening event. Sea-level rise, sediment starvation, and organic production initiated anoxic to euxinic bottom water conditions. Facies 1 was deposited in a relatively shallow sea with a stratified water column, where oxic conditions existed in the surface waters allowing zooplankton, such as styliolinids, and phytoplankton to produce organic matter. As a result, the abundant organic matter rained through the water column and depleted oxygen at a greater rate than oxygen demand (Alpin and Macquaker, 2011). Coagulation of organic matter with clay-sized sediments formed aggregate grains that settled quick enough to escape oxidation. These organic, clay aggregates, in the right quantity, are 
believed to enhance delivery to anoxic bottom waters and the preservation of organic matter during burial (Boyce, 2010, Bohacs et al., 2009).

Facies 1 consisted of polycrystalline quartz and sub-angular quartz-silt, which are suggestive of silicified algae clasts and eolian silt from windblown nutrients and sediments (Sageman et al., 2003). A faint, planar lamination was identified in thin-section, which could potentially represent algae blooms or eolian events. The high quartz percentage could also be attributed to diagenetic processes, since illitization generates excess silica. Bedding consisted of faint, discontinuous laminations likely due to the coagulation of organic matter and sediments that produced a random fabric making bedding appear massive (Tucker, 2001). A high concentration of pyrite is expected among organic-rich mudstone due to anoxic-sulfidic conditions. Such conditions prohibited interaction of benthic organisms, and therefore, no bioturbation, burrows, or fossils were noted in thin-section or core.

Facies 2, organic-rich mudstone, is also considered to be a condensed section that was developed during a transgressive systems tract(TST) or early regressive systems tract (RST). Bottom-water conditions were most likely anoxic to lower dysoxic in nature. Dysoxic conditions formed due to a zone of low oxygen that resulted from bacterial decomposition of organic matter falling from fertile oxic surfaces water. Seasonal events or storms may have caused the stratified water column to mix allowing enough oxygen to support dysoxic conditions, and conceivably allowing nutrients and sediments to change the water chemistry (Tucker, 2001). It is also possible that oxygenated bloom waters infiltrated sediment and provided burrowing organisms with a means to temporarily survive (Egenhoff and Fishman, 2013). Compacted illite blebs identified as horizontal burrows and scattered skeletal fragments were the result of such benthic fauna (Fig. 5.11, UM-8). Large silt-sized grains were identified as algal cysts, which are indicative of windblown nutrients and sediments. Pyrite is highest in facies 2 and occurs as replacement and dispersed framboids, and suggests an excess of sulfate in 
sediment during diagenesis or bacterial activity near the oxic-anoxic interface (Abouelresh and Slatt, 2011). The range of total organic carbon (TOC) and approximate averaged gamma-ray response was slightly lower than Facies 1, which supports more oxygen in the water column.

Gray siliceous shale (Facies 3) and gray mudstone (Facies 4) were deposited during a RST that exhibited both progradational and aggradational thickening of sediments. Bottom water conditions varied from anoxic to dysoxic, and on occasion from dysoxic to lower oxic. Facies 3 and 4 were located in a shallower and better oxygenated environment that allowed for more benthic diversity in comparison to Facies 1 and 2. Organic content was moderate with average TOC for facies 3 and 4 of 3.0 and $2.6 \mathrm{wt}$. $\%$, with a maximum of 5.1 wt. \% (Fig. 6.2), which implies that anoxic to dysoxic conditions dominated over oxic conditions. The most obvious difference between these facies was quartz and clay content. This could be a reflection of changes in clastic source, climate, or energy levels. Facies 3 has higher quartz relative to clay and is the most common facies. It is possible that Facies 3 experienced more terrigenous input, and thus, greater sedimentation rates formed a thicker facies. Furthermore, a higher rate of sedimentation, even if organic sediments were included, could decrease oxygen availability. This could explain why Facies 4 has a greater abundance of burrows, dispersed skeletal fragments, and body fossils. Clastic input may have decreased or changed due to a shift in the drainage system, and may have resulted in a calmer depositional environment, allowing for the aggregation and deposition of claysized grains. Facies 4 is associated with the most calcite-filled fractures and concretions, which could suggest slightly different pore waters than other facies, since the chemistry of the pore water is known to affect precipitation of concretions and mineralogy of sediment during early diagenesis (Tucker, 2001).

Gray calcareous shale (Facies 5) was deposited during a RST or during the early stages of a TST, or due to rapid, localized changes in bottom-water conditions from anoxic-dysoxic to oxic. In Facies 1 through 4, average carbonate weight percent is below $8 \mathrm{wt} . \%$, and calcareous content is often associated 
with concretions, mineralized fractures, microfossils, and the replacement of body fossils. Average carbonate weight percent for Facies 5 is $29.8 \%$, and consisted of biogenic lime mixed with clastics. Strong wavy laminations show evidence of vertical and horizontal burrows, as well as some bioturbation, indicative of dysoxic to oxic water conditions in shallow, low energy environment. Skeletal fragments and body fossils, such as moldic brachiopods, crinoids, styliolinids, and microfossils, are common and occasionally formed skeletal laminations. Organic matter is present in Facies 5 as discontinuous streaks.

Facies 6, argillaceous limestone, was deposited during a late RST and subsequent lowstand in sea-level. Facies 6 is often associated or interbedded with Facies 5. Thin beds of Facies 6 found in the Marcellus Formation suggest rapid, localized changes between oxic and anoxic conditions rather than a sharp drop in sea-level, specifically within the TST or early RST. The presence of abundant fossils, such as brachiopods, crinoids, and styliolinids supports deposition in shallow, oxic waters, where clastic input and energy was low. Bioturbation ranges from sparse to strong in nature, indicating that sediments were sub-oxic to oxic.

Facies 7, calcareous concretions, are localized and grow in the sediment during early diagenesis and take place below the sediment-water interface. Evidence of differential compaction of sediment around the concretion (Fig 5.9) suggests that sediments were soft when concretions started to form (Tucker, 2001). These concretions occur in close proximity with mineralized fractures and are often rimmed with pyrite, which is associated with bacterial activity near an oxic-anoxic interface (Alpin and Macquaker, 2001). Precipitation of these concretions is directly related to water chemistry, relative Eh and $\mathrm{pH}$, of the pore waters in the sediment during early diagenesis. Facies 7 contains or is in close proximity with coarse, calcite fractures that often widen towards the interior. This widening is a sign of shrinkage and excess pore pressure within the sediment (Tucker, 2001). 


\section{Sequence Stratigraphic Interpretation}

The sequence stratigraphic framework was developed from the interpretation of lithofacies stacking patterns and gamma-ray (GR) response. There were three different GR responses observed in the cored well: upward increasing, upward decreasing, and constant. An upward increasing GR pattern is interpreted as with a transgressive systems tract(TST), where an increase anoxia created organic condensed sections. An upward decreasing and constant GR pattern is associated with a regressive systems tract (RST), which includes highstand systems tract (HST) and lowstand system tracts (LST), previously discussed in section 2.4 (Fig 2.6). During RST, anoxia varied from anoxic to sub-oxic to oxic causing rapid fluctuations in gamma-ray and lithofacies. Two major surfaces, the maximum regressive surface (MRS) and the maximum flooding surface (MFS), were identified at the beginning and end of the TST. The MRS is located where the lowest GR and most oxic conditions exist, while the MFS is located where GR and anoxia are highest. Based on the criteria above, six stratigraphic intervals, consisting of partial or complete TST or RST cycles, were identified for the cored interval (Abouelresh and Slatt, 2011).

\subsection{Sequence Stratigraphic Intervals}

Sequence stratigraphic interpretation of the cored well spans a depth interval from $6988.50 \mathrm{ft}$. to $7162.15 \mathrm{ft}$. in log depth. The cored well was divided into 6 sequence stratigraphic intervals based on stacking patterns defined from GR response, lithofacies log, and core data. The intervals are outlined in Figures 1 through 4 in appendix B. These figures act as a visual model of the sequence stratigraphic framework for the Coldstream well. In addition to identifying stratigraphic intervals, the visual model highlights spectral core GR, lithofacies log, DRP lithofacies, lithology, sedimentary and structural features, as well as the $\mathrm{Th} / \mathrm{K}$ curve. 
Stratigraphic interval 1 (7147.15 - 7162.15 ft. [2178.5 - 2183.0 m]) (appendix B, Fig. 1) is associated with the Onondaga Limestone, and is recognized by its low GR response. Limestone is the primary facies, but it also includes a few thin calcareous shale intervals, ash beds 4 and 5 (Fig. 2.5), and a thin interval of siliceous, glauconitic shale at the base. The blue DRP lithofacies dominates, indicative of organically poor, calcite-rich rock. The presence skeletal fragments, wavy laminations, and bioturbation suggest the presence of oxygen in the sediments and water column. Interval 1 is identified as a being deposited during a lowstand in sea-level as it approaches the MRS. The MRS represents the contact between stratigraphic interval 1 and interval $2(7135.5-7147.15 \mathrm{ft} .[2175-2178.5 \mathrm{~m}])$ (appendix B, Fig. 1), also the contact between the Onondaga Limestone and lower Marcellus. The contact between the Onondaga and lower Marcellus is sharp, irregular, and well defined, transitioning into calcareous shale (interval 2) that is interbedded with limestone (Fig. 2.5). This suggests that oxic to dysoxic conditions persisted in the beginning stages of interval 2 creating fluctuations in anoxia.

The calcareous shale at the base of interval 2 contains ash beds 1,2 , and 3, and ash bed 1 actually caps the calcareous shale (Fig. 2.5). Above ash bed 1 is a thin bed of organic-rich mudstone (Facies 2), which lies below a large calcareous concretion that separates Facies 2 from organic-rich siliceous shale (Facies 1). Interval 2 displayed an overall upward increasing GR pattern associated with a rise in sea-level or an increase in anoxia. However, there was a thin bed of calcareous shale and limestone at 7138.5 to $7139.5 \mathrm{ft}$. (2175.8 - 2176.1 m) that separated the two high GR, Facies 1, intervals. The change in facies is most likely the result of an increase in oxygen rather than a base-level change, especially since there was no erosional surface. This could potentially be the result of a storm or seasonal event that caused mixing in the stratified water column or from a change in sediment supply. The MFS is located at the contact between interval 2 and stratigraphic interval $3(7088-7135.5 \mathrm{ft}$. [2160.4-2175 m]). 
Interval 3 (appendix B, Fig. 1 and 2) comprises an overall upward decreasing to constant GR signature typical of a RST. Gray siliceous shale (Facies 3) is the primary lithofacies, followed by Gray mudstone (Facies 4). Gradational contacts dominate between these facies, and interpretation of their boundaries was determined by GR response, as well as XRD and TOC data. However, at the base of this interval, at 7130.5 to $7132.5 \mathrm{ft}$. (2173.4 - $2174.0 \mathrm{~m})$, there is an increase in GR and the deposition of organic-rich lithofacies (appendix B, Fig.1). The deposition of organic-rich facies could be the result of a highstand in sea-level (Kohl, 2014) (Fig. 2.7). Total organic carbon (TOC) percent was not as high as in the TST of interval 2, indicating the slowing down of organic production possibly attributed to dilution or decomposition of organic matter because the overall RST is becoming more dysoxic. This organic-rich feature might suggest a temporary retrograde in shoreline, but more likely an increase in organic preservation due to short-term deficiency in oxygen. From 7092.5 to $7130.5 \mathrm{ft}$. (2161.8 $2173.4 \mathrm{~m}$ ), more oxidizing conditions and terrestrial input are interpreted through core description as well as $\mathrm{Th} / \mathrm{K}$ and $\mathrm{Th} / \mathrm{U}$ ratio curves (Fig. 5.21).

At the top of this interval, just below the Purcell Limestone, the lithofacies become more calcareous (7092.5 ft. [2161.8 m]) with evidence of skeletal laminations, which support increasingly oxic bottom water conditions. The Purcell Limestone could mark a lowstand in sea-level, with the top being the MRS. Alternatively, Boyce (2010) believed that deposition of the Purcell Limestone was initiated by changes in sediment supply, paleo-topography, and water chemistry. It is suggested that sea-level would have to drop significantly in order for the Purcell to be deposited from changes in sealevel alone. The Purcell Limestone in the study well is relatively thin, only encompassing $3 \mathrm{ft}$., and core descriptions lacked evidence of erosional surfaces or sharp contacts, which supports Boyce (2010) beliefs on localized variations in anoxia, which might be attributed to water chemistry alone, specifically changes in Eh. 
Stratigraphic interval 4 (7083 - 7088 ft. [2158.9 - 2160.4 m]) (appendix B, Fig. 2) is interpreted as deposited during a TST, and is supported by an upward increasing GR pattern. Interval 4 is composed of organic-rich mudstone separated by a thin bed of dark-gray siliceous shale. GR response is not as high as in the lower Marcellus, which could be associated with more terrestrial input causing dilution from a better established drainage network (Lash and Engelder, 2011). The MFS separates stratigraphic interval 4 from stratigraphic interval 5 and is marked by 2 pyrite bands, signifying a change in pore water chemistry.

Stratigraphic interval 5 (7041.5 - 7083 ft. [2146.2 - 2158.9 m]) (appendix B, Fig. 2 and 3) consists of an overall constant to upward decreasing GR pattern that is interpreted as a RST. The lithofacies in this interval are gray siliceous shale and gray mudstone, with lesser amounts of calcareous shale, limestone, and organic-rich mudstone. This interval has the highest number of calcareous concretions (Facies 7) and mineralized fractures. Interval 5 is separated into two sections, A and B. Section A extends from 7065 to $7083 \mathrm{ft}$. (2153.4 - 2158.9 m), while section B is from 7041.5 to $7065 \mathrm{ft}$. (2146.2 - 2153.4 m), ending at the upper Marcellus - Mahantango contact (appendix B, Fig. 2). Section A is comprised of Facies 3 with three calcareous concretion intervals and is topped with a thin, argillaceous limestone bed with abundant fossils and bioturbation (Fig. 5.4). Section B contains mostly gray mudstone facies that increases in grain-sized up the interval. Fossils, small and large calcareous concretions, mineralized fractures, as well as calcite and pyrite bands are very abundant and bedding appears to be at a low angle (appendix B, Fig. 3). However, at the base of section B, from 7062 to 7065 ft. $(2152.5-2153.4 \mathrm{~m})$, there is an upward increase in GR that ends with organic-rich mudstone facies. This sudden increase in GR, after the limestone interval of section A, represents a sudden change from oxic to lower anoxic-dysoxic, rather than a brief change rise in sea-level. The fluctuation in anoxia could be the result of a change in water chemistry or brief change in sediment supply. High 
precipitation of calcite and pyrite upwards in the interval indicates a change in pore water chemistry. At the contact between the upper Marcellus and Mahantango, interval 5 and 6 , there is assumed to be a MFS between the two formations.

Stratigraphic interval $6(6988.5-7041.5 \mathrm{ft}$. [2130 - 2146.2 m] (appendix B, Fig. 3 and 4) is interpreted to be the basal part of the Mahantango Formation or Skaneateles Shale (Fig. 2.3). The Stafford Limestone, which usually separates the upper Marcellus from the Mahantango is absent from this cored well. Interval 6 comprises a RST, with an overall upward decreasing GR pattern, especially compared to the Marcellus Formation. Interval 6 was deposited closer to the sediment source, consequently increasing the sediment supply and diluting organic matter, which is consistent with the decrease in TOC and GR. Water conditions became increasing more oxic, indicated by Th/U curve (Fig. 5.22). High energy and sedimentation rates prevented the precipitation of limestone as seen in previous intervals.

The DRP lithofacies correlated better with the defined sequence stratigraphic intervals than the core-scale lithofacies. The red and pink DRP color-coded facies, which represents high to moderate organic matter and potentially more calcite/illite than quartz (Fig. 5.25), was associated with TST, intervals 2 and 4. The blue DRP color-coded facies was located primarily in interval 1 or where there were limestone intervals. The calcareous concretions or calcareous shale were associated with blue or pink DRP facies. Interval 3 contained mostly the green DRP facies, indicative of high organic content, and more quartz than calcite, which is consistent with XRD results and visual observations. Interval 5 had a combination of pink, cyan, and green, suggesting high to moderate organic content, and varying amounts of quartz and calcite. Interval 5 had the most calcite-filled fractures and calcareous concretions, which might have been the primary cause of the pink DRP facies. Interval 6 was primarily 
the cyan colored DRP facies, suggesting moderate organic matter and greater quartz than calcite, which is consistent with the interpretation of this interval.

\section{Discussion and Conclusions}

The Clearfield County (173.65 ft. [59.93 m]) cored well is located in the western part of the Appalachian basin. Prior research in this area revealed complex structure due to kink band folding, fracture swarms, and fault damage zones (Bowers, 2014, Roberts, 2013). Boyce (2010) and Yanni (2010) isopach maps of the Onondaga and Marcellus Formations (Fig. 3.3) showed that Clearfield County, specifically the study area, is located on the edge of a bathymetric low. Well logs from this area confirm that the Marcellus Formation becomes thinner on topographic highs, and became thicker in topographic lows. This is relatively consistent with Lash and Engelder (2011) interpretation that thinner, more organic-rich sediments were concentrated on topographic highs, while more organic-lean sediments ponded in bathymetric lows.

Furthermore, it was determined by mineralogical modeling of the Clearfield well that there were more quartz relative to clay, but that the clay portion consisted of equal parts of smectite and illite. Shuvajit Bhattacharya also generated a mineralogical model for two wells located in the more eastern part of the play, and reported that these wells contained dominantly illite and chlorite, as well as more calcite. This is significant since illite supports brittleness, while smectite is considered swelling clay and can hinder production, and the cored well is located in a low production area.

Seven lithofacies were identified from visual descriptions and quantitative interpretations using core analysis methods, such as core and thin-section description, mineralogical evaluation, TOC, spectral core GR, and digital rock physics.

- Core description and thin-section results reveal abundant calcite filled fractures, especially in the upper Marcellus. A few thin, argillaceous limestone beds and calcareous concretions are 
observed intermediately in the Marcellus Formation. Bedding consists of massively bedded limestone and shale beds, which exhibit moderate to faint laminations. Contacts are mostly gradational and erosional surfaces are minimal.

- Mineralogical data for the lower Marcellus shows higher quartz relative to clay with the upper Marcellus having almost equal parts quartz to clay. Calcite, dolomite, and pyrite are relatively similar for both the upper and lower Marcellus. Clay mineralogy consists mostly of mixed layer clays, consisting of illite and smectite. Carbonate content was relatively low in this well compared to others in the basin.

- Total organic carbon (TOC) for the lower Marcellus averaged 4.3 wt. \%, while the upper Marcellus averaged 3.8\%. Core derived TOC was compared to log derived TOC using TOC Schmoker, and a good correlation is observed between core and log derived TOC.

- Spectral Core Gamma Ray (GR) helped identify clay type, illite to smectite $(\mathrm{Th} / \mathrm{K})$ ratio, and $\mathrm{Th} / \mathrm{U}$ ratio to locate zones of more terrigenous input and oxidizing components. Spectral core GR also helped identify stacking patterns to aid in lithofacies identification and interpretation of stratigraphic intervals.

- Ingrain’s digital rock physics (DRP) ColorHD ${ }^{\circledR}$ lithofacies classification was successful at illustrating the small-scale variations in the core that could not be identified through traditional means of core analysis. DRP analysis showed better correlation to sequence stratigraphic intervals than individual core-scale lithofacies.

- Seven lithofacies are identified in the cored well: (1) organic-rich, siliceous shale, (2) organicrich mudstone, (3) gray siliceous shale, (4) gray mudstone (5) calcareous shale, (6) limestone, and (7) calcareous concretion horizons. A lithofacies log was generated using spectral core GR, quantitative interpretation, as well as visual descriptions. 
- Examination of GR stacking patterns and the lithofacies log defines six stratigraphic intervals, with two transgressive-regressive sequences in the Marcellus Formation.

- After careful examination of lithofacies and stratigraphic intervals it is determined that the sequence stratigraphic framework for the cored well indicates that the Marcellus Formation in the area was deposited during a relatively low energy, shallow sea environment, where degree of anoxia was neither persistent nor widespread like previously thought. Rapid fluctuations in anoxia are attributed to changes in water chemistry, sediment supply, and primary production, associated with close proximity to localized bathymetric lows and a nearby sediment source. 


\section{REFERENCES CITED}

Abouelresh, M.O., Slatt, R.M., 2012, Lithofacies and sequence stratigraphy of the Barnett Shale in eastcentral Fort Worth Basin, Texas: AAPG Bulletin, v.96, no.1, p. 1-22.

Aplin, A.C., and J.H.S. Macquaker, 2011. Mudstone diversity: Origin and implications for source, seal, and reservoir properties in petroleum systems. American Association of Petroleum Geologists Bulletin, v. 95, p. 2031-2059.

Blakey, R., 2010, Middle Devonian (385Ma), North American Paleogeography. http://www2.nau.edu/ rcb7/globaltext2.html, accessed October 2, 2013.

Brett, C. E., G. C. Baird, A. J. Bartholomew, M. K. DeSantis, and C. A. V. Straeten, 2011, Sequence stratigraphy and a revised sea-level curve for the Middle Devonian of eastern North America: Paleogeography, Paleoclimatology, Paleoecology, v. 304, p. 21-53.

Bratovich, M., 2012, Comprehensive Petrophysical Shale Reservoir Evaluation: The foundation for shale asset life cycle management. Turkish International Oil and Gas Conference. Baker Hughes: presentation.

Bohacs, K.M. and Lazar, O.R., 2010, Sequence Stratigraphy in Fine-grained Rocks, in Schieber, J., Lazar, R., and Bohacs, K. eds., Sedimentology and stratigraphy of shale: American Association Petroleum Geologists 2010 Annual Convention in New Orleans Field Guide for Post-Convention Field Trip 10, p. 15-30.

Bohacs, K., MacQuaker, J., Lazar, O. R., Jonk, R., Hemmesch, N., Cassel, E. J., 2009, Detailed anatomy of parasequences in mudstone-dominated, allegedly anoxic settings: examples from the Cretaceous Mowry Shale and associated formations, western U.S.: AAPG Annual Convention and Exhibition, Denver, Colorado, June 7-10.

Bohacs, K.M., and Schroeder, F., 2010, Introduction to key concepts of sequence stratigraphy and their history, in Abreu, V., Neal, J., Bohacs, K.M., and Kalbas, J.L., eds, Sequence stratigraphy of siliciclastic systems: The Exon Mobil Methodology: Textbook: in press. SEPM Concepts in Sedimentology and Paleontology \# 9.

Bowers, C., 2014, Analyzing Fracture Stimulation of Middle Devonian Strata in Clearfield County, Pennsylvania Using a 3D Geomechanical Fault Model and Microseismic. Master's Thesis, West Virginia University, Morgantown, West Virginia, p 7,22, 77, 81-82.

Boyce, M., 2010, Sub-Surface Stratigraphy and Petrophysical Analysis of the Middle Devonian interval of the Central Appalachian Basin; West Virginia and Southwest Pennsylvania, PHD Dissertation, West Virginia University, Morgantown, p. 64-64,133-137.

Carter, K.M., Harper, J.A., Schmid, K.W., and Kostelnik, J., 2011, Unconventional natural gas resources in Pennsylvania: The backstory of the modern gas play: Environmental Geosciences, v. 18, no. 4, p. 217-257. 
Castle, J.W., 2001, Appalachian basin stratigraphic response to convergent-margin structural evolution: Basin Research, v. 13, p. 397-418.

Dennison, J., 1985, Catskill Delta shallow marine strata, in Woodrow, D.L., and Sevon, W.D., eds., The Catskill Delta: Geological Society of America special paper 201, p. 91-106.

De Witt, W., Jr., W. Perry, and L. Wallace, 1975, Oil and gas data from Devonian and Silurian rocks in the Appalachian Basin, Miscellaneous Investigations Series - U. S. Geological Survey, United States U. S. Geological Survey, Reston, VA, United States

De Witt, W., Jr., J. Roen, and L. Wallace, 1993, Stratigraphy of Devonian black shale and associated rocks in the Appalachian Basin, in J. Roen, and R. Kepferle, eds., U. S. Geological Survey Bulletin, United States, U. S. Geological Survey, Reston, VA, United States p. B1-B57.

Egenhoff, S.O., and Fishman, N.S., 2013, Traces in the Dark-Sedimentary Processes and Facies Gradients in the Upper Shale Member of the Upper Devonian-Lower Mississippian Bakkan Formation, Williston Basin, North Dakota, USA: Journal of Sedimentary Research, v.83, p.803824.

Erenpreiss, M. S., L. H. Wickstrom, C. J. Perry, R. A. Riley, D. R. Martin, and others, 2011, Regional organic-thickness map of the Marcellus Shale with additional organic-rich shale beds in the Hamilton Group included for New York, Pennsylvania, and West Virginia: Ohio Department of natural Resources, Division of Geological Survey, <http:/geosurvey.ohiodnr.gov/portals/ geosurvey/Energy/Marcellus/Regional_Marcellus\%20thickness_cntrlpts_8x11.pdf $>$ Accessed August 20, 2014.

Ettensohn, F.R., 1985, The Catskill Delta complex and the Acadian orogeny: A model, in Woodrow, D.L., and Sevon, W.D. (Eds.): The Catskill Delta: Geological Society America Special Paper 201, p. 39-49.

Ettensohn, F., 1987, Rates of relative plate motion during the Acadian Orogeny based on the spatial distribution of black shale: Journal of Geology, v. 95, p. 572-582.

Ettensohn, F., and Carlton, B. 2002, Stratigraphic evidence from the Appalachian Basin for continuation of the Taconian Orogeny into Early Silurian time: Physics and Chemistry of the Earth, v. 27, p. 279-288.

Ettensohn, F. 2004, Modeling the nature and development of major Paleozoic clastic wedges in the Appalachian Basin, USA: Journal of Geodynamics, v. 37, p. 657-681.

Faill, R. T., 1997, A Geologic History of the Northern-Central Appalachians, Part 1: Orogenesis from the Mesoproterozoic through the Taconic Orogeny: American Journal of Science, v. 297, p. 551619. 
Faill, R. T., 1997, A Geologic History of the Northern-Central Appalachians, Part 2: The Appalachian Basin from the Silurian through the Carboniferous: American Journal of Science, v. 297, p. 729761.

Fettke, C. R., 1961, Well-sample descriptions in northwestern Pennsylvania and adjacent states, Pennsylvania Geological Survey, 4th ser., Mineral Resource Report 40, 691 p.

Harper, J.A., 1999, Devonian, in Shultz, C.H., ed., The geology of Pennsylvania: Pennsylvania Geological Survey and Pittsburgh Geological Society, p. 108-127.

Ingrain Digital Rock Physics Lab." Ingrain. N.p., 2011. Web. 03 Apr. 2014. <http://www. ingrainrocks.com>.

Kaufmann, B., 2006, Calibrating the Devonian time scale: A synthesis of U-Pb ID-TIMS age and conodont stratigraphy: Earth Science Reviews, v. 76, p. 175-190, doi:10.1016/j.earscirev.2006.01.001.

Kohl, Daniel, Slingerland, Ruby, Arthur, Mike, Bracht, Reed, and Engelder, Terry. 2014, Sequence stratigraphy and depositional environments of the Shamokin (Union Springs) Member, Marcellus Formation, and associated strata in the middle Appalachian Basin: AAPG Bulletin, v. 98 , no. 3, p. 483-513.

Lash, Gary G., and Engelder, Terry. 2011, Thickness trends and sequence stratigraphy of the Middle Devonian Marcellus Formation, Appalachian Basin: Implications for Acadian foreland basin evolution: AAPGBulletin, v. 95, no. 1, p. 61-103.

Lazar, R., K. Bohacs, J.H.S. Macquaker, and J. Schieber, 2010, Fine-grained Rocks in Outcrops: Classification and Description Guidelines, in Schieber, J., Lazar, R., and Bohacs, K. eds., Sedimentology and stratigraphy of shale: American Association Petroleum Geologists 2010 Annual Convention in New Orleans Field Guide for Post-Convention Field Trip 10, p. 3-14.

Lindholm, R. C., 1969, Carbonate Petrology of the Onondaga Limestone (Middle Devonian), New York: A Case for Calcisiltite: Journal of Sedimentary Petrology, v. 39, p. 268-275.

Loucks, R.G., R.M. Reed, S.C. Ruppel, and U. Hammes, 2012, Spectrum of pore types and networks in mudrocks and a descriptive classification for matrix-related mudrocks pores: AAPG Bulletin, v. 96, no. 6, p. 1071-1098.

Macquaker, J. H. S., K. G. Taylor, M. Keller, and D. Polya, 2013, Compositional controls on early diagenetic pathways in fine-grained sedimentary rocks: Implications for predicting unconventional reservoir attributes of mudstones, (in press; preliminary version published online Ahead of Print 09 September 2013): AAPG Bulletin, doi: 10.1306/08201311176.

Milici, R.C., and Swezey, C.S., 2006, Assessment of Appalachian basin oil and gas resources; Devonian Shale-Middle and Upper Paleozoic total petroleum system: U.S. Geological Survey Open-File Report 2006-1237, p. 1-70. 
Milliken, K.L., Esch, W.L., Reed, R.M., and Zhang, T., 2012, Grain assemblages and strong diagenetic overprinting in siliceous mudrocks, Barnett Shale (Mississippian), Fort Worth Basin, Texas: AAPG Bulletin, v. 96, no. 8, p. 1553-1578.

Ochoa, J., J. Wolak, and M. H. Gardner, 2013, Recognition criteria for distinguishing between hemipelagic and pelagic mudrocks in the characterization of deep-water reservoir heterogeneity: AAPG Bulletin, v. 97, no. 10, p. 1785-1803.

Passey, Q.R., Bohacs, K.M, W.L., Esch, Klimentidis, R., and S. Sinha, 2010, From Oil Prone Source Rock to Gas-Producing Shale Reservoir-Geologic and Petrophysical Characterization of Unconventional Shale Gas Reservoirs: CPS/SPE International Oil and Gas Conference, Beijing, June 8, 2010.

Parrish, C., 2013, Insights into the Appalachian Basin Middle Devonian Depositional System from U-Pb Zircon Geochronology of Volcanic Ashes in the Marcellus Shale and Onondaga Limestone. Master's Thesis, West Virginia University, Morgantown, West Virginia, p10-11, 20-23, 31, and 69.

Roberts, E., 2013, Structure Segmentation and Transfer Faults in the Marcellus Shale, Clearfield County, PA: Implications for Gas Recovery Efficiency and risk Assessment in Central Appalachian Basin Using 3D Seismic Attribute Analysis, Master's Thesis, West Virginia University, Morgantown, p. 94.

Ryder, R.T., Trippi, M.H., Swezey, C.S. Crangle, R.D., Jr., Hope, R.S., Rowan, E.L., and Lentz, E.E., 2012, Geologic cross section $C-C$ 'through the Appalachian basin from Erie County, northcentral Ohio, to the Valley and Ridge province, Bedford County, south-central Pennsylvania: U.S. Geological Survey Scientific Investigations Map 3172, 2 sheets, 70-p. pamphlet. (Also available at http://pubs.usgs.gov/sim/3172/.)

Sageman, B., A. Murphy, J. Werne, C. Ver Straeten, D. Hollander, and T. Lyons, 2003, A tale of shale; the relative roles of production, decomposition, and dilution in the accumulation of organic-rich strata, Middle-Upper Devonian, Appalachian Basin: Chemical Geology, v. 195, p. 229-273.

Scanlin, M., and T. Engelder, 2003, The Basement Versus the No-Basement Hypotheses for Folding within the Appalachian Plateau Detachment Sheet: American Journal of Science, v. 303, p. 519563.

Schmoker, J.W., 1994, Volumetric calculation of hydrocarbons generated, in L.B. Magoon, and W.G. Dow, (eds.), The petroleum system; from source to trap: AAPG Memoir 60, p. 323-326.

Scotese, C.R., and McKerrow, W.S., 1990, Revised World maps and introduction: Paleogeography and Biogeography, Geological Society Memoir No. 12, p. 1-21.

Sexton, R. L., 2011, Sequence stratigraphy, distribution and preservation of organic carbon, and reservoir properties of the Middle Devonian Marcellus Shale, of the central Appalachian basin; 
northern West Virginia and southwestern Pennsylvania. Master's Thesis, West Virginia University, Morgantown, West Virginia, p8-9.

Shanks, A.L., 2002, The abundance, vertical flux, and still-water and apparent sinking rates of marine snow in a shallow coastal water column: Continental Shelf Research, v.22, p.2045-2064.

Tourtelot, Harry, 1979, Black Shale - Its Deposition and Diagenesis: Clays and Clay Minerals, v. 27, no. 5, p. 313-321.

Tucker, M.E., 2001, Sedimentary Petrology: An introduction to the origin of sedimentary rocks. ( $3^{\text {rdEd. }}$ ) ,Malden, MA: Blackwell Science Ltd.

Ver Straeten, C. A., 2004, K-bentonites, volcanic ash preservation, and implications for Early to Middle Devonian volcanism in the Acadian orogen, eastern North America: Geological Society of America Bulletin, v. 116, no. 3, p. 474-489.

Ver Straeten, C. A., 2007, Basin wide stratigraphic synthesis and sequence stratigraphy, upper Pragian, Emsian and Eifelian stages (Lower to Middle Devonian), Appalachian Basin: Geological Society, London, Special Publication 278, p. 39-81.

Ver Straeten, C.A., and C.E. Brett, 2006, Pragian to Eifelian strata (mid Lower to lower Middle Devonian), northern Appalachian Basin-A stratigraphic revision: Northeastern Geology, v. 28, p. 80-95.

Ver Straeten, C.A., C. E. Brett, and B. B. Sageman, 2011, Mudrock sequence stratigraphy: A multiproxy (sedimentological, paleobiological, and geochemical) approach, Devonian Appalachian Basin: Palaeogeography, Palaeoclimatology, Palaeoecology, v. 304, p. 54-73.

Walker-Milani, M. E., 2011, Outcrop lithostratigraphy and petrophysics of the Middle Devonian Marcellus Shale in West Virginia and adjacent states. Master's thesis, West Virginia University, Morgantown, West Virginia, p. 7, 25-44.

Wang, Guochang, and Carr, Timothy R., 2012, Methodology of organic-rich shale lithofacies identification and prediction: A case study from Marcellus Shale in the Appalachian basin: Computers \&Geosciences, v. 49, p. 151-163.

Werne, J., B. Sageman, T. Lyons, and D. Hollander, 2002, An integrated assessment of a "type euxinic" deposit; evidence for multiple controls on black shale deposition in the Middle Devonian Oatka Creek Formation: American Journal of Science, v. 302, p. 110-143.

Woodward, D.L., Fletcher, F.W., and Ahrnsbrak, W.F., 1973, Paleogeography and Paleoclimate at the Deposition Sites of the Devonian Catskill and Old Red Facies: Geological Society of America Bulletin, v. 84, p. 3051-3064.

Woodrow, D.L., Dennison, J.M., Ettensohn, F.R., Sevon, W.T., and Kirchgasser, W.T., 1988, Middle and Upper Devonian stratigraphy and paleogeography of the central and southern Appalachians 
and eastern mid-continent, U.S.A., in McMillan, N.J., Embry, A.F., and Glass, D.J., eds., Devonian of the World: Canadian Society of Petroleum Geologists Memoir 14, v. 1, p. 277-301.

Wrightstone, Gregory, 2009, Marcellus Shale - Geologic Controls on Production: AAPG Annual Convention, Denver, CO, USA, June 7, 2010.

Yanni, A., 2010, Subsurface Stratigraphy and Petrophysical Analysis of the Middle Devonian Interval Including the Marcellus Shale, of the Central Appalachian Basin; Northwestern Pennsylvania, Master's Thesis, West Virginia University, Morgantown, p. 35-36, 60.

Zagorski, W., G. Wrightstone, and D. Bowman, 2012, The Appalachian Basin Marcellus Gas Play: Its History of Development, Geologic Controls on Production, and Future Potential as a World-class Reservoir: AAPG Memoir, v. 97, p. 172-200. 
APPENDIX A

\begin{tabular}{|c|c|c|c|c|c|c|c|c|}
\hline \multirow{2}{*}{ Sample ID } & \multirow{2}{*}{$\begin{array}{l}\text { Log Depth } \\
\text { (ft.) }\end{array}$} & \multirow{2}{*}{$\begin{array}{l}\text { Core Depth } \\
\text { (ft.) }\end{array}$} & \multicolumn{4}{|c|}{ XRD Mineralogy } & \multirow{2}{*}{$\begin{array}{c}\text { TOC } \\
\text { (wt.\%) }\end{array}$} & \multirow{2}{*}{ FACIES } \\
\hline & & & Quartz & Carbonate & Pyrite & Clay & & \\
\hline PA-Mah27 & 6994.50 & 7008.00 & 45 & 4 & 2 & 50 & 1.22 & 4 \\
\hline MAH-17 & 6996.00 & 7009.50 & 37.7 & 5 & 1.6 & 55.7 & 0.98 & 4 \\
\hline PA-Mah28 & 7001.50 & 7015.00 & 52 & 4 & 3 & 40 & 1.62 & 3 \\
\hline MAH-16 & 7005.50 & 7019.00 & \begin{tabular}{l|l}
44.5 \\
\end{tabular} & 1.1 & 1.1 & 53.3 & 1.8 & 4 \\
\hline PA-Mah26 & 7007.50 & 7021.00 & 54 & 5 & 3 & 39 & 1.96 & 3 \\
\hline MAH-15 & 7014.50 & 7028.00 & 43 & 2 & 4.4 & 50.6 & 2.62 & 4 \\
\hline PA-Mah29 & 7020.25 & 7033.75 & 53 & 4 & 4 & 40 & 1.91 & 3 \\
\hline PA-Mah30 & 7022.50 & 7036.00 & 55 & 4 & 2 & 38 & 1.96 & 3 \\
\hline MAH-14 & 7024.50 & 7038.00 & 42.7 & 0.4 & 4.7 & 52.1 & 2.51 & 4 \\
\hline PA-Mah25 & 7025.30 & 7038.80 & 51 & 6 & 3 & 40 & 2.38 & 3 \\
\hline MAH-13 & 7035.50 & 7049.00 & 33.6 & 21.2 & 4.9 & 40.2 & 2.29 & 5 \\
\hline PA-Mah24 & 7036.15 & 7049.65 & 50 & 12 & 2 & 37 & 1.9 & 3 \\
\hline PA-UM23 & 7045.05 & 7058.55 & 52 & 5 & 3 & 39 & 2.15 & 3 \\
\hline UM-12 & 7045.50 & 7059.00 & 36.6 & 0 & 6.6 & 56.9 & 5.14 & 4 \\
\hline PA-UM22 & 7051.05 & 7064.55 & 51 & 5 & 3 & 41 & 2.2 & 3 \\
\hline PA-UM31 & 7055.75 & 7069.25 & 36 & 32 & 4 & 29 & 2.71 & 5 \\
\hline PA-UM21 & 7056.50 & 7070.00 & \begin{tabular}{|l|l|}
46 \\
\end{tabular} & 7 & 5 & 42 & 3.01 & 3 \\
\hline UM-11 & 7056.50 & 7070.00 & 27.9 & 36.8 & 5.1 & 30.1 & 2.33 & 5 \\
\hline PA-UM20 & 7061.00 & 7074.50 & 45 & 1 & 6 & 48 & 3.6 & 4 \\
\hline PA-UM19 & 7064.70 & 7078.20 & 42 & 13 & 8 & 37 & 3.04 & 3 \\
\hline UM-10 & 7065.50 & 7079.00 & 29.2 & 6.8 & 23.6 & 40.3 & 6.54 & 2 \\
\hline PA-UM32 & 7068.90 & 7082.40 & 48 & 0 & 9 & 42 & 2.96 & 3 \\
\hline UM-9 & 7075.50 & 7089.00 & 49.1 & 0.3 & 8.7 & 41.9 & 5 & 3 \\
\hline PA-UM18 & 7081.95 & 7095.45 & 48 & 5 & 6 & 41 & 3.47 & 3 \\
\hline PA-UM17 & 7084.50 & 7098.00 & 51 & 5 & 6 & 38 & 3.52 & 3 \\
\hline UM-8 & 7086.00 & 7099.50 & 38.9 & 1 & 12.2 & 47.8 & 7.28 & 2 \\
\hline PA-CV16 & 7088.55 & 7102.05 & 49 & 3 & 9 & 39 & 4.73 & 3 \\
\hline
\end{tabular}

Table 1. Table listing samples from the Mahantango, upper Marcellus, and Purcell Limestone units that were analyzed for mineralogy using the XRD and pyrolysis for TOC. Facies associations were assigned to individual samples: (2) organic-rich shale, (3) gray siliceous shale, (4) gray mudstone, and (5) calcareous shale. 


\begin{tabular}{|c|c|c|c|c|c|c|c|c|}
\hline \multirow{2}{*}{ Sample ID } & \multirow{2}{*}{$\begin{array}{l}\text { Log Depth } \\
\text { (ft.) }\end{array}$} & \multirow{2}{*}{$\begin{array}{l}\text { Core Depth } \\
\text { (ft.) }\end{array}$} & \multicolumn{4}{|c|}{ XRD Mineralogy } & \multirow{2}{*}{$\begin{array}{c}\text { TOC } \\
\text { (wt. \%) }\end{array}$} & \multirow{2}{*}{ FACIES } \\
\hline & & & Quartz & \begin{tabular}{|l|} 
Carbonate \\
\end{tabular} & Pyrite & Clay & & \\
\hline LM-7 & 7093.50 & 7107.00 & 41.1 & 16.9 & 3.4 & 38.6 & 4.23 & 3 \\
\hline PA-LM15 & 7094.90 & 7108.40 & 50 & 9 & 6 & 35 & 3.88 & 3 \\
\hline PA-LM14 & 7100.95 & 7114.45 & 34 & 5 & 5 & 56 & 3.07 & 4 \\
\hline PA-LM13 & 7105.50 & 7119.00 & 51 & 3 & 6 & 39 & 3.44 & 3 \\
\hline LM-6 & 7105.50 & 7119.00 & 39.8 & 13.4 & 8 & 38.8 & 5.14 & 3 \\
\hline PA-LM33 & 7111.25 & 7124.75 & 50 & 2 & 6 & 42 & 2.81 & 3 \\
\hline PA-LM12 & 7112.40 & 7125.90 & 52 & 3 & 5 & 39 & 2.84 & 3 \\
\hline PA-LM11 & 7113.50 & 7127.00 & 39 & 30 & 5 & 26 & 2.47 & 5 \\
\hline LM-5 & 7114.50 & 7128.00 & 37.8 & 13.9 & 13.5 & 34.8 & 4.38 & 3 \\
\hline \begin{tabular}{|l|} 
PA-LM10 \\
\end{tabular} & 7116.50 & 7130.00 & 52 & 5 & 6 & 38 & 2.93 & 3 \\
\hline PA-LM34 & 7120.25 & 7133.75 & 51 & 4 & 5 & 40 & 2.83 & 3 \\
\hline PA-LM9 & 7121.35 & 7134.85 & 54 & 3 & 5 & 38 & 2.57 & 3 \\
\hline LM-4 & 7121.50 & 7135.00 & 44.6 & 8.9 & 8.2 & 38.3 & 3.63 & 3 \\
\hline PA-LM35 & 7123.35 & 7136.85 & 47 & 13 & 5 & 35 & 2.87 & 3 \\
\hline PA-LM8 & 7126.50 & 7140.00 & 49 & 9 & 7 & 35 & 2.71 & 3 \\
\hline LM-3 & 7131.50 & 7145.00 & 43.9 & 3.6 & 9.5 & 43.1 & 6.26 & 2 \\
\hline PA-LM7 & 7132.25 & 7145.75 & 49.5 & 2 & 8.9 & 39.6 & 5.96 & 1 \\
\hline PA-LM36 & 7135.20 & 7148.70 & 50 & 5 & 6 & 39 & 3.28 & 3 \\
\hline PA-LM6 & 7136.60 & 7150.10 & 43 & 5 & 12 & 40 & 6.02 & 1 \\
\hline PA-LM5 & 7140.85 & 7154.35 & 47 & 6 & 12 & 35 & 7.18 & 1 \\
\hline PA-LM4 & 7141.25 & 7154.75 & 42.4 & 5 & 16.2 & 36.4 & 9.12 & 1 \\
\hline LM-2 & 7142.00 & 7155.50 & 63.1 & 14.5 & 8.9 & 13.5 & 8.25 & 1 \\
\hline PA-LM Ash6 & 7143.15 & 7156.65 & 35 & 3 & 5 & 57 & 7.8 & 2 \\
\hline PA-LM Ash5 & 7143.75 & 7157.25 & 56.4 & 12.9 & 2 & 28.7 & 6.36 & 1 \\
\hline PA-On3 & 7146.75 & 7160.25 & 47 & 26 & 2 & 25 & 5.96 & 5 \\
\hline PA-LM Ash4 & 7147.20 & 7160.70 & 33.3 & 33.3 & 2 & 31.5 & 3.49 & 5 \\
\hline PA-On Ash3 & 7148.90 & 7162.40 & 29 & 20 & 2 & 49 & 5.32 & 5 \\
\hline PA-On Ash2 & 7149.75 & 7163.25 & 10 & 81 & 1 & 8 & 1.54 & 6 \\
\hline PA-On Ash1 & 7150.20 & 7163.70 & 26 & 54 & 2 & 19 & 2.84 & 6 \\
\hline PA-On2 & 7151.30 & 7164.80 & 34 & 39 & 2 & 25 & 3.51 & 5 \\
\hline $\mathrm{ON}-1$ & 7151.50 & 7165.00 & 6.2 & 91.7 & 0.9 & 1.2 & 0.49 & 6 \\
\hline PA-On1 & 7159.60 & 7173.10 & 48 & 11 & 2 & 39 & 1.3 & 3 \\
\hline
\end{tabular}

Table 2. Table listing samples from the lower Marcellus, and Onondaga Limestone units that were analyzed for mineralogy using the XRD and pyrolysis for TOC. Facies associations were assigned to individual samples: (1) organic-rich siliceous shale, (2) organic-rich shale, (3) gray siliceous shale, (4) gray mudstone, (5) calcareous shale, and (6) limestone. 


\section{APPENDIX B}

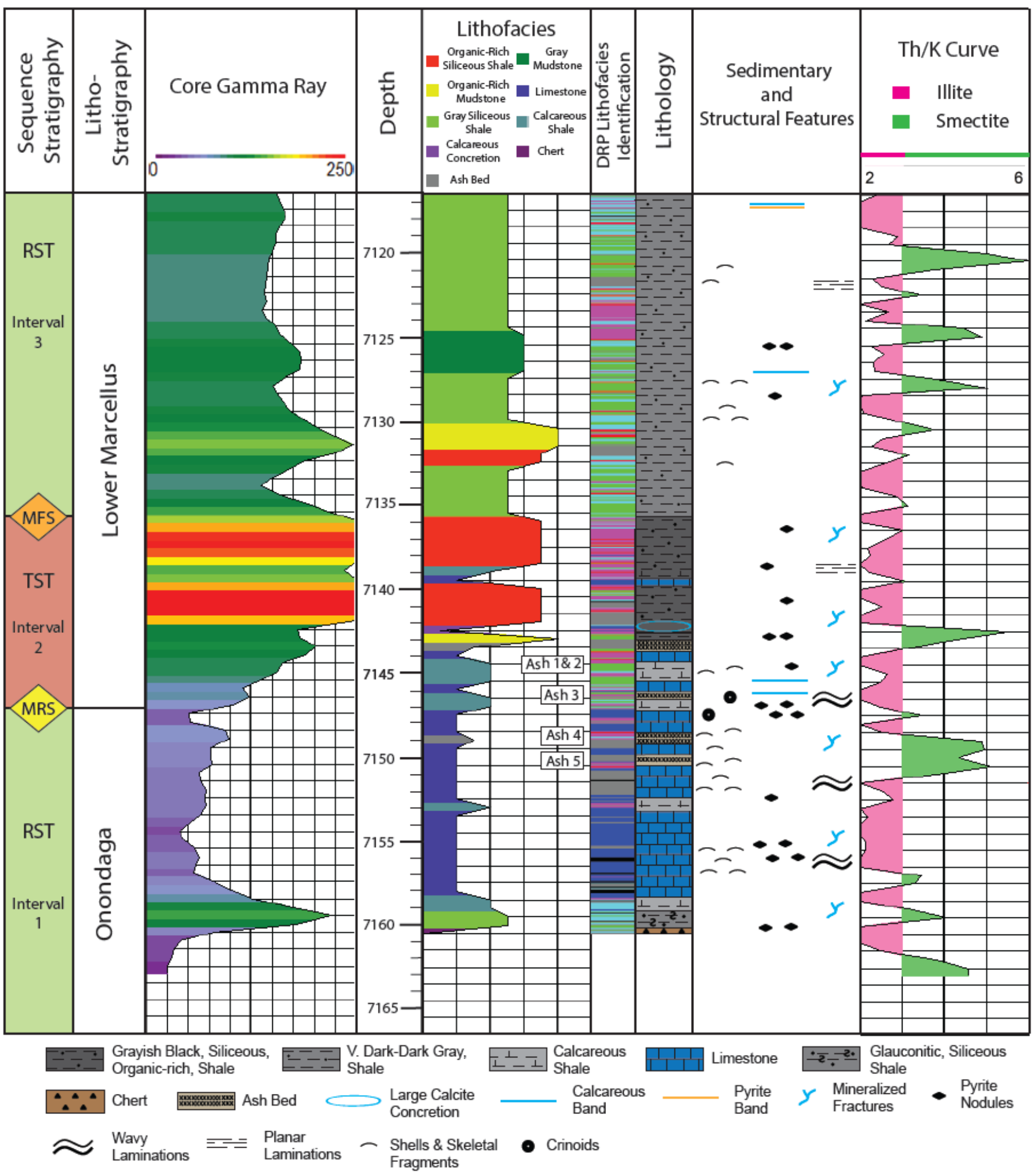

Figure 1. Sequence Stratigraphic Framework model showing lithofacies, DRP lithofacies, sedimentary and structural features, and $\mathrm{Th} / \mathrm{K}$ curve for basal lower Marcellus and Onondaga Limestone. Use Figure 5.25 to reference a key for the DRP color-coded facies. 


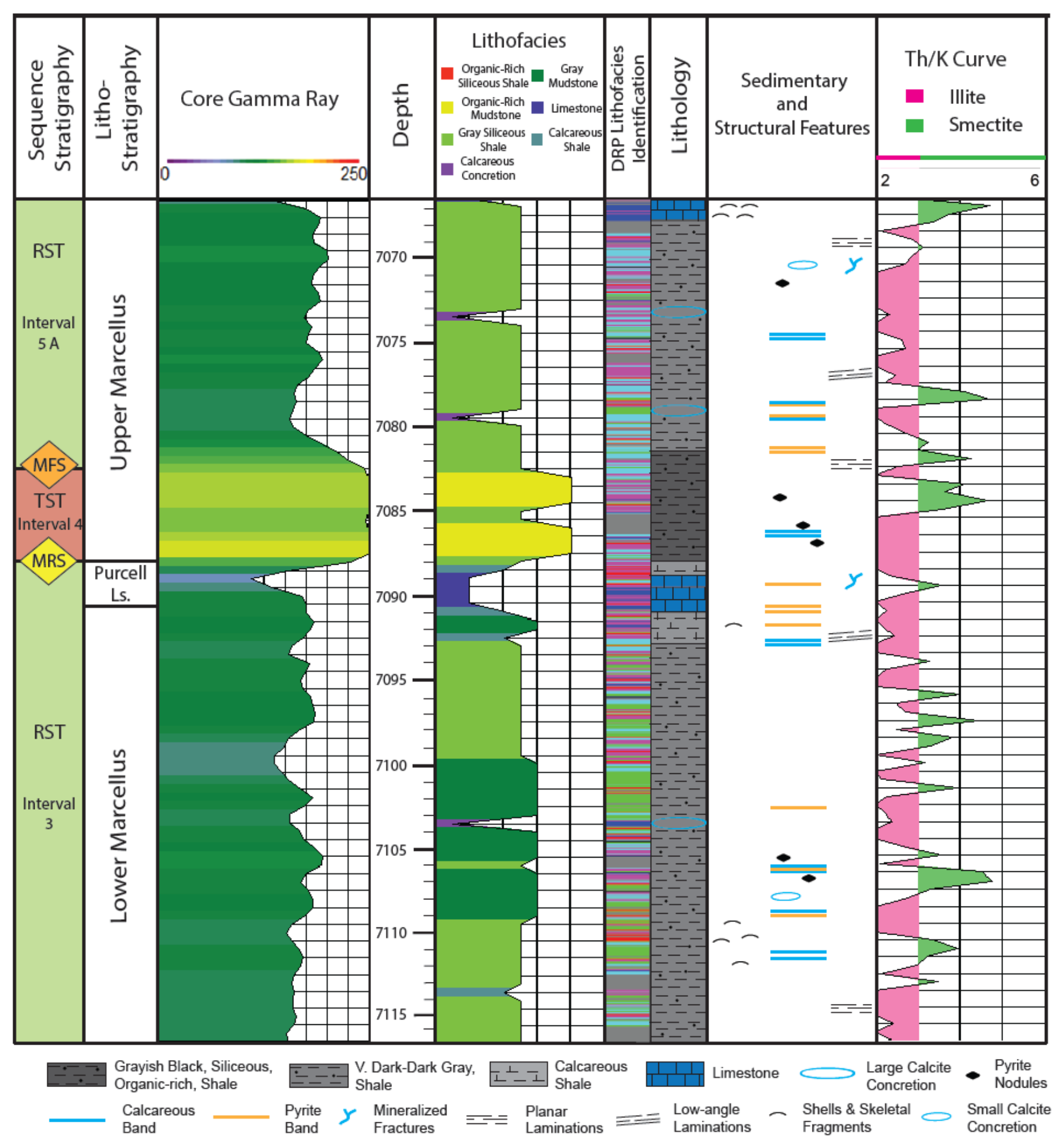

Figure 2. Sequence Stratigraphic Framework model showing lithofacies, DRP lithofacies, sedimentary and structural features, and Th/K curve for upper part of the lower Marcellus, Purcell Limestone, and upper Marcellus. Use Figure 5.25 to reference a key for the DRP color-coded facies. 


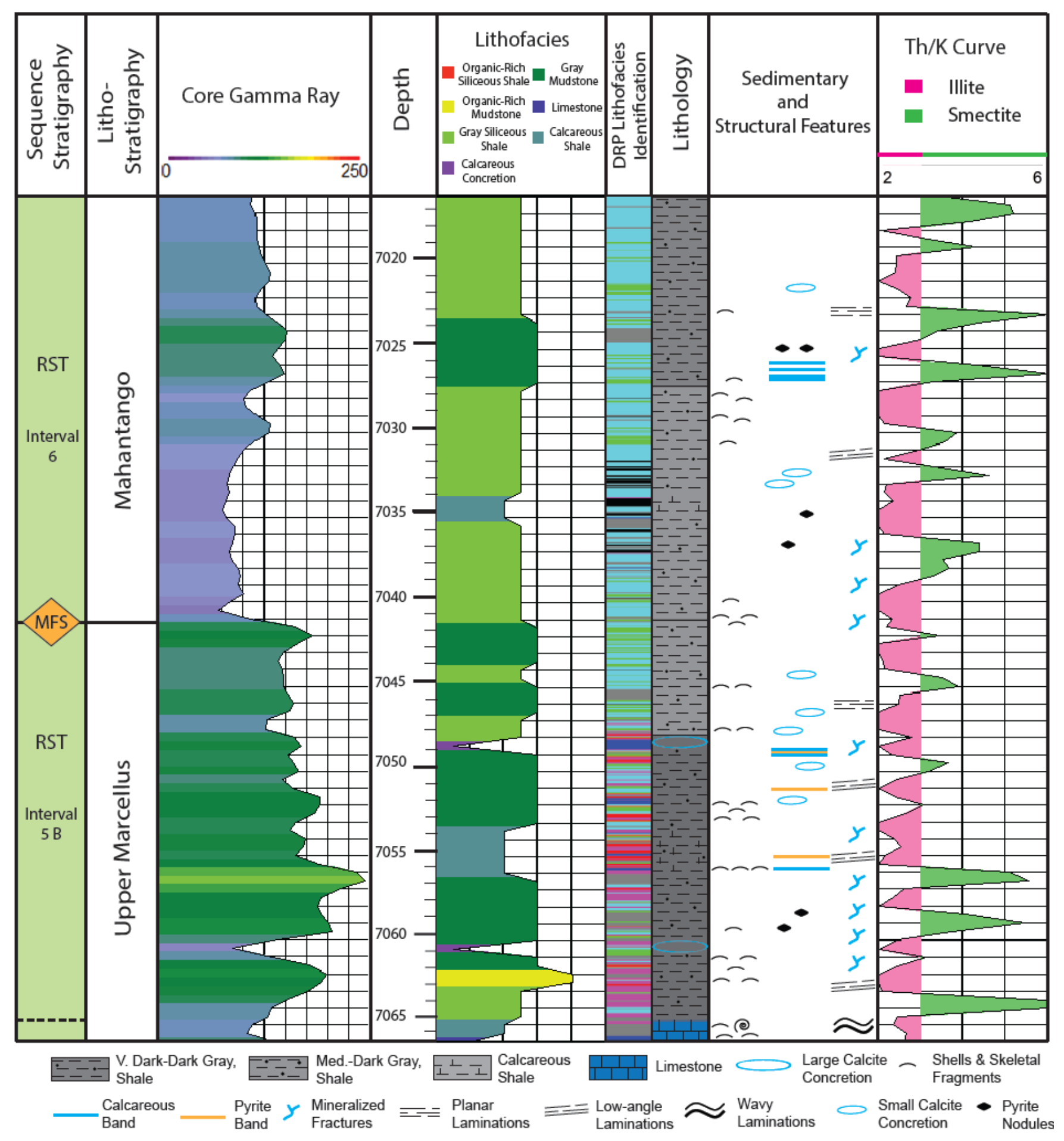

Figure 3. Sequence Stratigraphic Framework model showing lithofacies, DRP lithofacies, sedimentary and structural features, and $\mathrm{Th} / \mathrm{K}$ curve for the upper Marcellus and Mahantango. Use Figure 5.25 to reference a key for the DRP color-coded facies. 


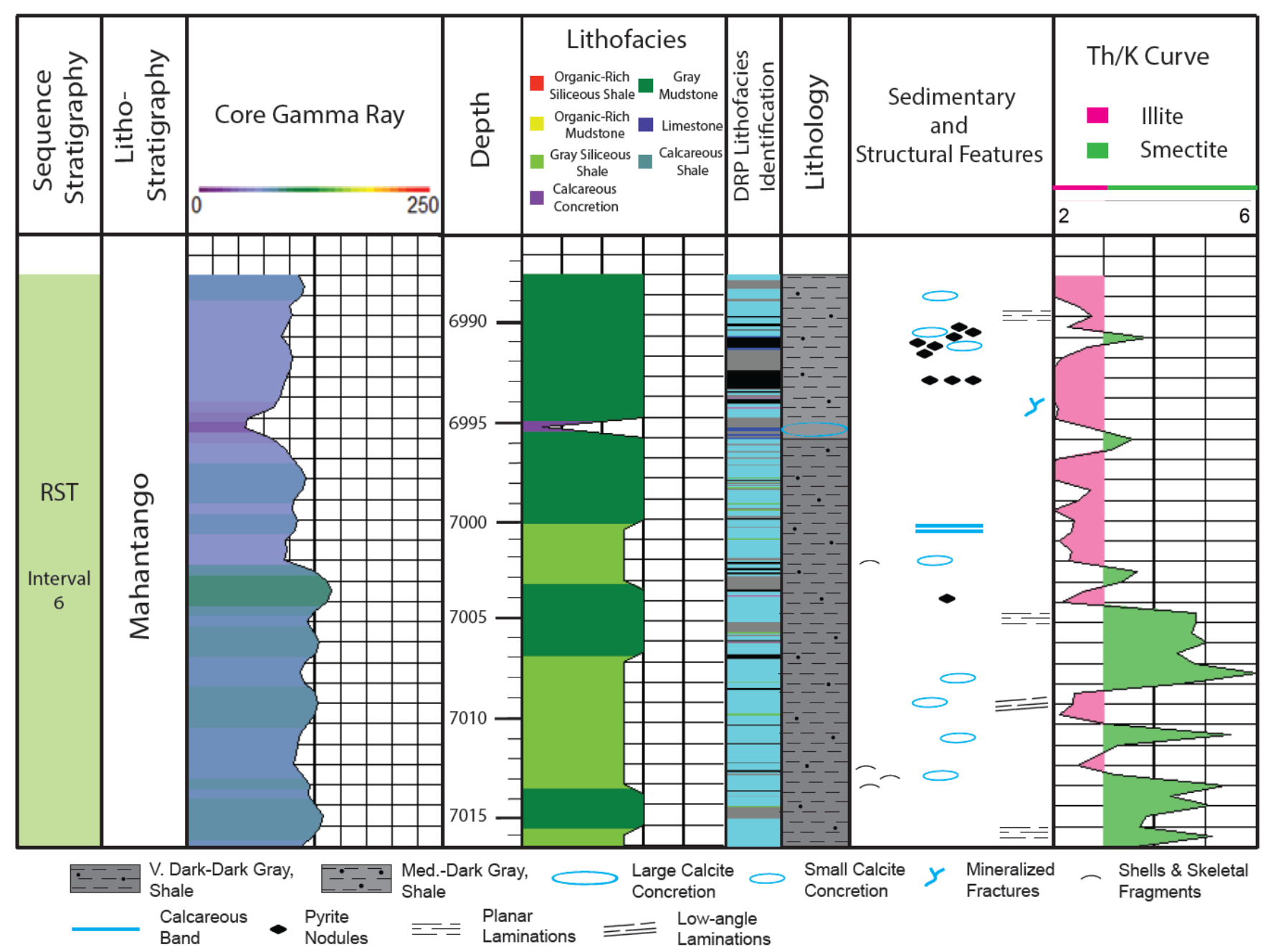

Figure 4. Sequence Stratigraphic Framework model showing lithofacies, DRP lithofacies, sedimentary and structural features, and $\mathrm{Th} / \mathrm{K}$ curve for the Mahantango Formation. Use Figure 5.25 to reference a key for the DRP color-coded facies. 